\title{
IPO WAVES, PRODUCT MARKET COMPETITION, AND THE GOING PUBLIC DECISION:
}

\author{
THEORY AND EVIDENCE
}

by

\author{
Thomas J. Chemmanur* \\ Carroll School of Management \\ Boston College
}

and

\author{
Jie He* \\ Terry College of Business \\ University of Georgia
}

CES 12-07

March, 2012

The research program of the Center for Economic Studies (CES) produces a wide range of economic analyses to improve the statistical programs of the U.S. Census Bureau. Many of these analyses take the form of CES research papers. The papers have not undergone the review accorded Census Bureau publications and no endorsement should be inferred. Any opinions and conclusions expressed herein are those of the author(s) and do not necessarily represent the views of the U.S. Census Bureau. All results have been reviewed to ensure that no confidential information is disclosed. Republication in whole or part must be cleared with the authors.

To obtain information about the series, see www.census.gov/ces or contact Cheryl Grim, Editor, Discussion Papers, U.S. Census Bureau, Center for Economic Studies, 4600 Silver Hill Road, Washington, DC 20233, CES.Papers.List@census.gov. 


\begin{abstract}
We develop a new rationale for IPO waves based on product market considerations. Two firms, with differing productivity levels, compete in an industry with a significant probability of a positive productivity shock. Going public, though costly, not only allows a firm to raise external capital cheaply, but also enables it to grab market share from its private competitors. We solve for the decision of each firm to go public versus remain private, and the optimal timing of going public. In equilibrium, even firms with sufficient internal capital to fund their new investment may go public, driven by the possibility of their product market competitors going public. IPO waves may arise in equilibrium even in industries which do not experience a productivity shock. Our model predicts that firms going public during an IPO wave will have lower productivity and post-IPO profitability but larger cash holdings than those going public off the wave; it makes similar predictions for firms going public later versus earlier in an IPO wave. We empirically test and find support for these predictions.
\end{abstract}

*For helpful comments and discussions, we thank Kenneth Ahern, Pierluigi Balduzzi, Walid Busaba, David Chapman, Craig Dunbar, Joseph Fan, Shan He, Clifford Holderness, Gang Hu, Jiekun Huang, Tim Jenkinson, Yawen Jiao, Karthik Krishnan, Praveen Kumar, Alan Marcus, Ronald Masulis, Debarshi Nandy, Tom Noe, Neil Stoughton, Paul Povel, Jun Qian, Jonathan Reuter, Ronnie Sadka, Philip Strahan, Robert Taggart, Hassan Tehranian, and Xuan Tian. We also thank seminar participants at Boston College, The Chinese University of Hong Kong, Concordia University, George Washington University, Hebrew University of Jerusalem, Nanyang Technological University, National University of Singapore, Oxford University, Singapore Management University, Tel-Aviv University, University of Georgia, University of Houston, University of Illinois at Chicago, University of New South Wales, University of Western Ontario, and conference participants at the RICAFE 2008 conference at Amsterdam, the FIRS 2009 Meetings at Prague, the 2009 Southwestern Finance Association Meetings, the 2009 Financial Management Association Meetings, the 2009 Midwestern Finance Association Meetings, the 2009 Eastern Finance Association Meetings, the 2009 Northern Finance Association Meetings, and the 2009 Southern Finance Association Meetings for helpful comments. Special thanks to Bill Schwert and an anonymous referee for several helpful comments. The research presented in this paper was conducted while the authors were special sworn status researchers at the Boston Research Data Center of the U.S. Census Bureau. Any opinions and conclusions expressed herein are those of the authors and do not necessarily represent the views of the U.S. Census Bureau. All results have been reviewed to ensure that no confidential information is disclosed. Any remaining errors or omissions are the responsibility of the authors. 


\section{IPO Waves, Product Market Competition, and the Going Public Decision: Theory and Evidence}

\section{Introduction}

The existence of IPO waves, otherwise known as "hot" IPO markets, has been widely documented: see, e.g., Ritter (1984). The reasons for the existence of such IPO waves, however, are less widely understood. Two recent theoretical models of IPO waves are Pastor and Veronesi (2005) and Alti (2005). Pastor and Veronesi (2005) argue that IPO waves are generated due to the "real option" effect of going public: entrepreneurs possess a real option to take their firms public, invest part of the IPO proceeds, and begin producing, and, in a setting of time-varying market conditions, choose the best time to exercise this option. When stock market conditions are sufficiently favorable (expected market return is low, expected aggregate profitability is high, and prior uncertainty is high), many entrepreneurs exercise their options to go public, thus generating an IPO wave. Alti (2005) focuses instead on information spillovers across IPOs to generate IPO waves. He considers a setting in which IPOs are sold to institutional investors, who are asymmetrically informed about a valuation factor common across private firms. Since IPO offer prices are set based on investors' indications of interest, the outcome of an IPO (a high versus low IPO offer price) reflects information that was previously private, reducing information asymmetry across investors and reducing valuation uncertainty for future issuers, thereby triggering an IPO wave.

While the above two theoretical analyses have driving forces quite different from each other, they also have one feature in common: they are both driven by considerations of stock market valuation and stock returns: the aggregate stock market in the case of Pastor and Veronesi (2005), and stock valuation in the IPO market in the case of Alti (2005). While stock market valuation is indeed an important driving force behind the creation of IPO waves, another driving force that has not been analyzed so far in the literature is product market competition. The objective of this paper is to develop a theory of the timing of a firm's going public decision and IPO waves based on product market considerations that allow us to answer several interesting questions: First, which industries are most likely to have an IPO wave? Second, what are the differences between firms that go public "on the wave" (i.e., as part of an IPO wave) versus "off the wave" (i.e., either individually, or part of a cold IPO market) both in terms of pre-IPO productivity and post-IPO product market performance? Third, within the set of firms going public as part of an IPO wave, does timing matter: i.e., is there a difference in productivity and post-IPO performance (as well as other firm characteristics) between firms that go public earlier in an IPO wave versus later in the wave ${ }^{1}$ Our theoretical

\footnotetext{
${ }^{1}$ While we are not aware of any prior empirical analyses of this question, there is some anecdotal evidence that higher quality firms go public earlier in an IPO wave: see, e.g., the Harvard Business School Case ImmuLogic Pharmaceutical Corporation (B-2). To quote: "The one certainty about the current open window for biotechnology initial public offerings (IPOs) was that sooner or later it would shut again. Furthermore, he (Henry McCance) has observed that in past periods of intense IPO activity, the best firms tended to go public early in the cycle, while lower-quality firms went public later." See also Ritter and Welch (2002) for a discussion of practitioner
} 
model answers these and related questions, and we empirically test the implications of our theory.

Our theory departs from existing analyses with the assumption that going public not only allows a firm to raise capital at a lower cost than if it were a private firm, but also allows it to grab market share from competitors who remain private. It is particularly interesting to examine, both theoretically and empirically, the implications of the notion that going public enables a firm to grab market share from competitors in the product market, since there is some anecdotal evidence from practitioners that this is indeed the case in practice. ${ }^{2}$ We do not make any assumptions regarding the precise mechanisms through which firms going public early are able to grab market share from their competitors: possible mechanisms include gaining additional credibility with customers and suppliers; being able to hire higher quality employees as a public firm and rewarding them more efficiently using stock and stock options; and being able to acquire related firms in the same industry (holding patents valuable for introducing various product innovations) through takeovers paid for using their own (publicly traded) stock. ${ }^{3}$

We consider an industry with two firms: firm 1 and firm 2, both of which are private to begin with. Each firm has a scalable project with decreasing returns to scale, which it proposes to implement. Firm 1 has higher productivity of capital compared to firm 2, so that its equilibrium scale of investment is higher than that of firm 2. Each firm has a certain amount of internal capital available to it as a private firm. However, if the amount of capital required for investment exceeds the above internal capital, the firm needs to either scale back its investment (i.e. operate at a scale smaller than its optimal level) or raise external financing by going public. ${ }^{4}$ Thus, going public has two benefits in our setting: it allows the firm to raise external financing if necessary, and also allows it to grab market share from other firms in the industry that are private. On the other hand, going public is costly: we assume that each firm has to incur a significant cost if it chooses to go public.

Each firm knows its own productivity, and also that their industry may soon experience a positive productivity shock with a certain probability. We assume that, in the absence of a productivity shock, the available internal capital will be enough to fund the projects of both firm 1 and firm 2 at their optimal scale. If, however, a productivity shock is realized, firm 1 (which has higher productivity to begin with) needs to go public to raise external financing arguments on the timing of firms going public within an IPO wave.

${ }^{2}$ To quote Killian, Smith, and Smith (2001): "An IPO can establish its brand and gain loyal customers ahead of competitors. Palm established itself as the leader with a suite of spiffy handheld devices and great marketing, grabbing 80 percent of market share. Then Handspring, founded by Palm alums, created a device with a twist: add-on modules that allow Handspring users to download and play music or to access the Internet. Handspring priced its PDAs aggressively and captured most of the remaining (market) share. With these two aggressive players dominating PDA sales, it was very difficult for a new entrant to compete. Even Microsoft, with its billions of dollars of marketing clout, retreated from the field." Killian, Smith, and Smith (2001) also give a number of examples from other industries where firms that went public earlier were able to grab significant market share in their industry. Examples include Affymetrix, the maker of microchips that identify and analyze gene sequences; Petsmart, the pet superstore, which went public ahead of its competitor, pets.com, and grabbed significant market share; and Capstone Turbine, the maker of microturbines, which was the first to introduce such turbines for commercial use.

${ }^{3}$ Another possibility is that a public firm may compete more aggresively in the product market than a private firm, since a risk-averse entrepreneur may find it easier to diversify his personal portfolio and therefore care less about operating risk after going public: see Chod and Lyandres (2010), who develop a model formalizing this argument.

${ }^{4}$ Thus, for simplicity, we assume that it is prohibitively costly for the firm to raise external financing as a private firm. However, note that all our results go through as long as the cost of external financing is significantly cheaper for a public firm compared to that for a private firm. 
in order to operate at its new optimal scale, while firm 2 will continue to have enough internal capital to operate at its new optimal scale (since, given its lower level of initial productivity, its new optimal scale will be smaller than its available internal capital even after the productivity shock is realized). We allow a firm to go public either early (before the productivity shock is realized) or late (after the shock is realized). We assume that there will be two rounds of competition for market share between the two firms in the product market: one before the productivity shock is realized, and another one afterward.

We solve for the equilibrium time at which each firm goes public (if at all), which in turn determines whether or not there is an IPO wave (we define an IPO wave as a situation where both firms in the industry go public). There are five possible equilibria in our model, depending on the following four parameter values: the magnitude of a potential productivity shock; the probability of a productivity shock; the cost of going public; and the levels of initial productivity of each firm in the industry. Consider first the benchmark equilibrium, where going public merely allows a firm to raise external financing (and does not give it any advantage in terms of competing for market share). In this case, the lower productivity firm 2 remains private throughout, regardless of whether or not there is a productivity shock, since going public is costly and it has adequate capital to fund its project at its optimal scale even in the event of a productivity shock. Firm 1 will go public only if a productivity shock is realized, since going public does not give it any advantage in terms of competition for market share, and the only reason for going public is to raise external financing (which becomes necessary if and only if a productivity shock is realized).

Consider now the full-fledged model, where going public enables a firm to grab market share from competitors. There are three categories of equilibria in this case, depending on the model parameters discussed earlier. The first category of equilibria involves an IPO wave occurring even without the realization of a productivity shock: i.e., both firms go public early without waiting to see whether a productivity shock is realized or not. The second category of equilibria involves both firms going public, but at least one of the two firms goes public only if a productivity shock is realized: in other words, an IPO wave occurs only in the event of a productivity shock. The third category of equilibria involves firms going public off the wave: i.e., only one of the two firms goes public, and the other remains private throughout.

To understand the intuition behind the above equilibria, it is useful to consider the costs and benefits of going public versus remaining private, as well as those of going public early versus late. Consider first firm 1 . This firm has two benefits from going public. First, in the event of a productivity shock, its internal capital is not sufficient to fund its investment to its optimal level, so that it needs to raise additional capital by going public. Second, by going public, it can grab market share from firm 2, in the event that the latter remains private. Its cost of going public is the deadweight cost discussed earlier. Now consider firm 2. Since its productivity is lower, its only benefit from going public is to prevent firm 1 from grabbing market share from it (and to grab market share from firm 1 in the event that it does not go public); recall that we have assumed that firm 2's initial productivity is low enough that, 
even after the shock, it can still fund its investment at its optimal level using internal capital. Note, however, that a productivity shock nevertheless increases its benefit of going public, since its profits from additional market share will be greater if its productivity is greater. For either firm, the trade-off between going public early versus late is as follows. The advantage of going public early is that the firm is able to grab market share from the other firm (and to prevent the other firm from grabbing market share from it) in two rounds of product market competition. The disadvantage of going public early is that it incurs the cost of going public before it knows for sure whether a productivity shock is realized (so that the firm may end up being public in a situation where no shock is realized, and it would have been better off remaining private). Note that the benefit of going public early versus late is always greater for firm 1 than for firm 2 (since it has multiple reasons for going public, while firm 2 has only the benefit of grabbing market share); on the other hand, the cost of going public is the same for both firms. We show that the above trade-offs result in the higher productivity firm going public alone in equilibrium in the absence of an IPO wave. Further, if the equilibrium involves an IPO wave, the higher productivity firm always goes public either earlier than or at the same time as the lower productivity firm.

Our theoretical analysis yields several testable predictions. The first prediction is that, on average, firms going public outside an IPO wave (i.e. in a cold market) will have higher productivity and post-IPO profitability than those going public within an IPO wave. Second, on average, firms going public earlier in an IPO wave will have higher productivity and post-IPO profitability than those going public later in the wave. Third, since our model predicts that firms going public outside an IPO wave have higher average pre-IPO productivity, and given that higher-productivity firms have a larger optimal scale, firms going public in an IPO wave will on average hold more cash on hand than firms going public off the wave (for a given amount raised in the IPO). Similarly, our model predicts that firms going public later in an IPO wave will on average hold more cash on hand than firms going public earlier in the wave (for a given amount raised in the IPO).

Before testing the implications of our theory, we first provide some evidence regarding our model assumption that going public allows a firm to grab market share from competitors who remain private. For this empirical analysis, we make use of the Longitudinal Research Database (LRD) of the U.S. Census Bureau, which covers the entire universe of private and public U.S. manufacturing firms. We find that IPO firms experience an increase in their market share soon after they go public at the expense of their private competitors (Table 3). Further, IPOs in a given industry are associated with a reduction in the market share of same-industry competitors, and this negative correlation is larger for competitors that are private (Table 4$).{ }^{5}$ There are two possible scenarios that can explain the above findings. First, going public causes an increase in the IPO firm's market share and a reduction in its competitors' market share

\footnotetext{
${ }^{5}$ See also Hsu, Reed, and Rocholl (2010), who document that firms experience negative stock price reactions to completed IPOs in their industry and positive stock price reactions to IPO withdrawals. Further, they show that following a successful IPO in their industry, competing firms show significant deterioration in their operating performance. Slovin, Sushka, and Ferraro (1995) present similar evidence in the context of equity carve-outs.
} 
(which is our model assumption). Second, the anticipation of increased market share induces a firm to go public. Without a valid instrument for the going public decision of a firm, it is difficult to distinguish between the above two scenarios. Thus, while the above results are broadly consistent with the main assumption of our model, we do not wish to claim that going public causes an increase in market share. ${ }^{6}$ In other words, the objective of the above analysis is not to present convincing empirical support for the above assumption of our model. We believe that, like all other models, our model should be evaluated based on the evidence we present here regarding its predictions.

We test the predictions of our model using three different data sets. We obtain our overall IPO sample from the Thomson Financial Securities Data Corporation (SDC) new issues database. We obtain the data required to calculate the total factor productivity (TFP) and the market share of firms remaining private as well as those going public (or are already public) from the LRD of the U.S. Census Bureau. Finally, we obtain data on the accounting performance of IPO firms subsequent to going public (like ROA and cash holdings) from the Compustat database. To compare on-the-wave IPO firms versus off-the-wave ones in the same industry, we define the "hotness" of an IPO market as the total number of IPOs in the same Fama-French industry within a 90-day window symmetrically surrounding the issuance date for any given IPO and use this number as a raw measure of the hotness of the IPO market in that industry for the particular issuance date under consideration. Consistent with our first prediction, we find that a firm that goes public within a hot period of 8 other same-industry IPOs will on average have total factor productivity (TFP) 0.028 less than a firm that goes public within a cold period of only 1 other same-industry IPO. Given that the mean of TFP in our sample is 0.046 , this represents a $61 \%$ difference in TFP, which is economically significant. We also find that a firm that goes public within a hot period of 8 other same-industry IPOs will on average have a post-issuance ROA $1.1 \%$ less than a firm that goes public within a cold period of only 1 other same-industry IPO. Given that the mean of post-IPO ROA in our sample is 5\%, this represents a $20 \%$ difference in post-issuance operating performance. We also use two refinements of the above measure for hotness and find similar results.

To compare leaders and followers in an IPO wave for a particular industry, we first identify and define IPO waves within that industry and then rank the IPOs in our sample within each wave by the order of their issuance dates. Consistent with our second prediction, we find that a firm that goes public earlier in an IPO wave (among the first $25 \%$ of firms going public in this wave) will on average have TFP 0.081 more than a firm that goes public later in the wave (among the last 25\% of firms going public in this wave). Given that the mean of TFP in our sample is 0.046, this represents a $176 \%$ difference in TFP. Further, we find that a firm that goes public earlier in an IPO wave (among the first $25 \%$ of firms going public in the wave) will on average have an ROA $2.3 \%$ more than a firm that goes public later in the wave (among the last $25 \%$ of firms going public in the wave). Given that the mean ROA in our sample is $5 \%$, this represents a $46 \%$ difference in post-issuance ROA. Similar results hold if we use alternative

\footnotetext{
${ }^{6}$ It is difficult to find a convincing firm-level instrumental variable for a firm's going public decision that satisfies the exclusion restriction requiring that the variable, while correlated with the going public decision, should not directly affect the subsequent product market share of the firm going public.
} 
measures of how early an IPO takes place within a wave.

The above empirical results regarding the TFP as well as post-IPO profitability of firms going public on the wave versus off the wave, and that of firms going public early in a wave versus later in the wave are also consistent with the predictions of a variation on the model of Pastor and Veronesi (2005) which relies on stock market conditions (details in Section 7.2.1 and 7.3.1). We therefore conduct several robustness tests to distinguish our predictions from those of that model and find that, even after incorporating proxies for short-term and long-term market conditions as controls, there is residual empirical support for our model predictions.

We also find evidence supporting our other predictions. Our results show that, on average, firms that go public in an IPO wave will hold more cash on hand after the IPO and experience a larger increase in cash and cash equivalents around the IPO date than firms that go public off the wave. Similarly, we find that firms going public later in an IPO wave on average hold a larger cash balance on hand after the IPO and experience a larger increase in cash and cash equivalents around the IPO date than firms that go public earlier in the wave. Finally, since our model argues that product market competition is an important factor driving firms' going public decisions, we analyze whether and how industry concentration relates to the relationship between post-issuance operating performance and IPO timing ("on the wave" versus "off the wave", and "early in a wave" versus "later in the wave"). We find that a higher level of industry concentration tends to weaken the difference in post-IPO performance between firms that go public on the wave versus off the wave, and between firms going public earlier in a wave versus later in the wave. We discuss the implications of this finding for our theory in section 7.5.

Apart from the two theoretical analyses of IPO waves discussed earlier, the theoretical literature most directly related to this paper is the literature on the going public decision: see, e.g., Chemmanur and Fulghieri (1999) or Maksimovic and Pichler (2001). In a recent paper, Spiegel and Tookes (2007) develop a model of the relationship between product market innovation, product market competition, and the public versus private financing decision in an infinite horizon model. In their model, the advantage of going public is the ability to obtain cheaper financing while the disadvantage is the disclosure requirements associated with going public that allow competitors in the firm's industry to copy the innovation. Another related model is Pastor, Taylor, and Veronesi (2009), in which an entrepreneur trades off the diversification benefits of going public against the cost of doing so (the loss of his benefits of control), in the presence of Bayesian learning about the average productivity of his firm. IPO waves are not the main focus of the above models. ${ }^{78}$ In terms of empirical literature, this paper is most directly related to the papers

\footnotetext{
${ }^{7}$ Yung, Colak, and Wang (2008) develop a model in which time-varying investment opportunities lead to time-varying adverse selection in the IPO market. They test this model taking as given the premise that asymmetric information is revealed over time, and find that hot-market IPOs are associated with greater cross-sectional return variance and higher delisting rates. Khanna, Noe, and Sonti (2007) develop a model of going public in which screening IPOs requires specialized labor, which is in fixed supply. A sudden increase in demand for IPO financing increases the compensation of this screening labor, which results in reduced screening, resulting in sub-marginal firms entering the IPO market. Their model predicts increased underpricing in hot markets. Boot, Gopalan, and Thakor (2006) study an entrepreneur's choice between private and public ownership when insiders and outsiders disagree about the best way to maximize firm value.

${ }^{8}$ Our paper is also broadly related to the literature on product and financial market interactions: see, e.g., Chemmanur and Yan
} 
studying hot and cold IPO markets (see, e.g., Helwege and Liang 2004) and the literature studying fluctuations in IPO volume (see, e.g., Lowry 2003, Lowry and Schwert 2002, or Benveniste, Ljungqvist, Wilhelm, and Yu 2003). Unlike our paper, Helwege and Liang (2004) mostly study IPO waves in the entire equity market rather than with respect to each industry, and conclude that there is no difference in the quality of firms going public in hot and cold IPO markets. In contrast to their findings, our empirical analysis indicates that there is indeed a significant difference in both pre-IPO productivity and post-IPO operating performance (both in the short and the long run) between firms going public during an IPO wave versus those going public off the wave. The empirical literature on the going public decision (see, e.g., Pagano, Panetta, and Zingales 1998 or Chemmanur, He, and Nandy 2010) is also indirectly related to this paper. ${ }^{9}$

The rest of the paper is organized as follows. In section 2, we describe our model setup, and in section 3 we characterize its equilibria. We describe our testable predictions in section 4 and our data and sample selection procedures in section 5. We discuss variable construction and summary statistics in section 6 . In section 7 , we describe our empirical results and conclude in section 8.

\section{The Model}

We consider the going public decision of two competing private firms in an industry. For simplicity, we assume that the two firms are duopolies who split the total product market between them. The model has four dates (time 0, 1, 2 , and 3). At time 0 , the two private firms are endowed with the same amount of initial capital and the same form of cash-flow-generating technology. Firm 1 has a market share of $m$ and firm 2 has the rest $(1-m) \cdot{ }^{10}$ Without loss of generality, we assume firm 1 to have a higher productivity $A_{1}$ than firm 2 , with productivity $A_{2}\left(A_{1}>A_{2}\right)$. As we shall see in section 2.1, both firms' long-term (time 3) valuation increases with their market share and production efficiency (which depends on their productivity as well as their available capital).

At time 1, each firm knows that a productivity shock may take place at time 2, in which case its productivity may increase by amount $\Delta A(>0)$ with probability $p$. We denote the enhanced productivity of firm $i$ as $A_{i H} \equiv A_{i}+\Delta A$. Given this distribution of potential shocks, the firms will calculate their expected optimal capital level and may go public in case of an expected funding shortage. Going public, at a fixed cost of $B$, has two benefits. First, it can provide cheaper capital for a firm's production than debt or private placements (i.e., we assume that alternative financing methods are too costly to be feasible). Second, it can improve a firm's efficiency in grabbing market share

(2008), who analyze the relationship between product market advertising and new equity issues (IPOs and SEOs), and Stoughton, Wong, and Zechner (2001), who argue that the decision of a firm to go public may serve to signal high quality to the product market.

${ }^{9}$ Our paper is also broadly related to the large theoretical and empirical literature on IPOs: see, e.g., Chemmanur (1993), Allen and Faulhaber (1989), Welch (1989), and Grinblatt and Hwang (1989), for theoretical IPO models, and Ritter and Welch (2002) for a review.

${ }^{10}$ Since firms already gone public play no role in our model, we simply assume that they own zero market share. As a result, the sum of market share for the two private firms is assumed to be 1 . Alternatively, we can specify the sum of market share to be $\delta(0<\delta<1)$, which allows our subsequent analysis to go through unaffected. 
from its competitors, for example, by enhancing its credibility with customers and suppliers; allowing it to hire higher quality employees as a public firm and rewarding them more efficiently using stock and stock options; or allowing it to acquire related firms in the same industry through takeovers paid for using their publicly traded stock. After the firms make their going public decisions, they will start the first round of product market competition, the details of which will be discussed in section 2.2 .

At time 2, productivity shocks, if any, are realized, and a firm can go public at this stage if it hasn't already done so at time 1. The capital raised at this stage and the enhancement in its market-share-grabbing ability will also help the firm increase long-term (time 3) cash flows and thus raise its market valuation. The second round of product market competition now takes place and the total market share is redivided between the two rivals.

At time 3, the firms' long-run cash flows are realized and distributed to shareholders, and they liquidate. We assume that all agents (firm managers, shareholders, and investors) are risk-neutral and the risk free rate is zero. Everything in the model is publicly observable and information is symmetric. The sequence of events is depicted in Figure 1.

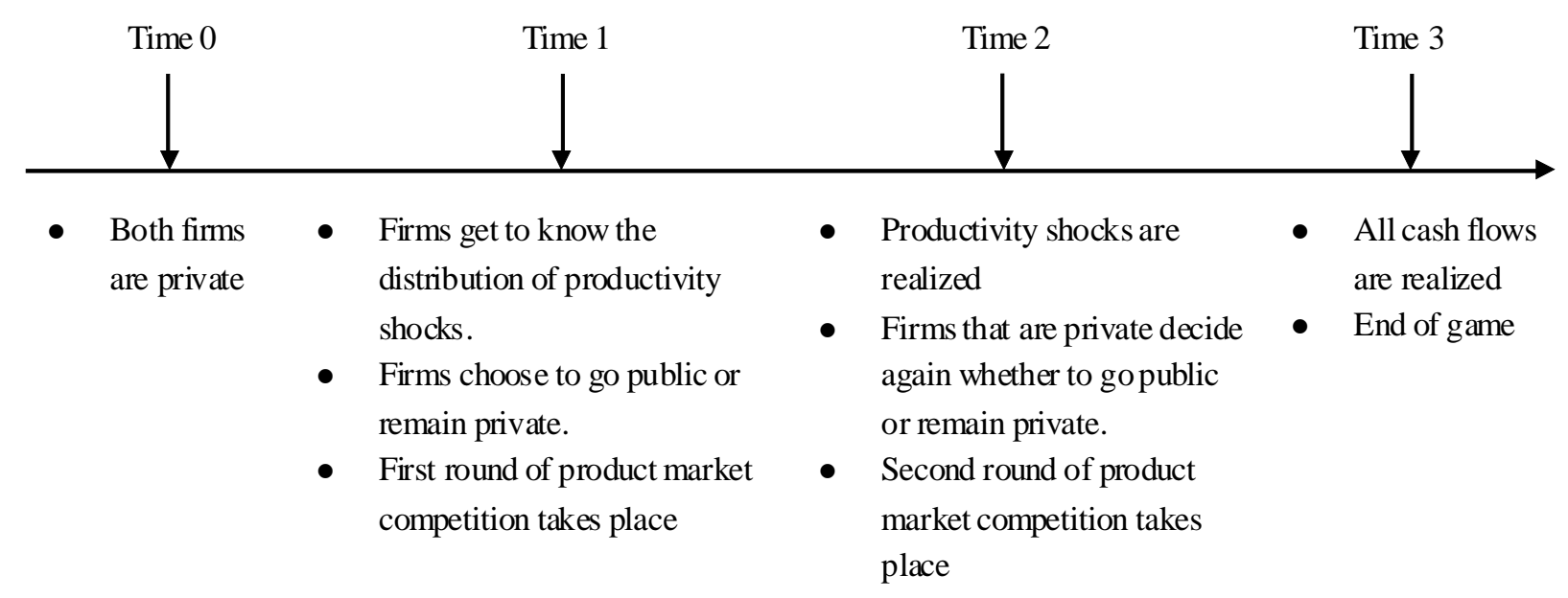

Figure 1: Sequence of Events

\subsection{The firm's problem}

Each firm's objective is to maximize its long-term cash flows at time 3, which depends on the amount of capital it uses to generate cash flows as well as its market share in the product market. Specifically, firm $i$ 's cash flow at time $3, V_{i}$, is given as follows:

$$
V_{i}=\left\{A_{i}^{I I}\left(m_{i}^{I I}\right)^{1-\gamma}\left(K_{i}^{*}\right)^{\gamma}-c K_{i}^{*}\right\}+K_{i}, 0 \leq K_{i}^{*} \leq K_{i}, i=1,2
$$


where $K_{i}$ is the amount of capital firm $i$ possesses at the end of time 2 . If the firm remains private for the two periods, then $K_{i}$ is simply $K_{0}$, its original capital endowment (which is assumed to be the same for both firms). If, on the other hand, firm $i$ goes public in any period (time 1 or 2 ), $K_{i}$ will become $K_{0}+E_{i}$, where $E_{i}$ denotes the amount of capital raised in the offering. $m_{i}^{I I}$ is firm $i$ 's market share at the end of time 2 (i.e., after two rounds of product market competition), whose level depends on both firms' going public decisions. The details of product market competition are provided in section 2.2. $A_{i}^{I I}$ is firm $i$ 's productivity at time 2 . If it experiences the productivity shock at time 2 , then $A_{i}^{I I}$ is $A_{i H}$. Otherwise $A_{i}^{I I}$ remains at $A_{i} . K_{i}^{*}$, the capital firm $i$ uses to generate cash flows, cannot exceed $K_{i}$, the total amount of capital it owns at time 2. $c$ is the constant marginal cost of deploying each unit of capital (i.e., it is the production cost per unit of capital), $0<c \leq 1$. Lastly, we adopt a Cobb-Douglas production function and assume that $0<\gamma<1$ so that the cash-flow generating technology exhibits decreasing returns to scale in its capital usage. ${ }^{11}$ All parameters are publicly known.

Given the above setup, it is straightforward to show that the efficient level of capital chosen by firm $i, K_{i}^{e}$, is linearly increasing in its long-term market share and also increasing in the firm's productivity: $K_{i}^{e} \equiv m_{i}^{I I}\left(A_{i}^{I I}\right)^{\frac{1}{1-\gamma}}(c / \gamma)^{\frac{1}{\gamma-1}}$ and $K_{i}^{*}=\operatorname{Min}\left[K_{i}^{e}, K_{i}\right]$.

\subsection{Product market competition}

Product market competition in this model involves the firms' campaign to gain market share by attracting each other's customers. ${ }^{12}$ There are two successive rounds of competition in our model, during which each firm relies on its own market power to launch marketing campaigns and to attract customers away from its rival. Specifically, the evolution of market share for firm $i$ is given by:

$$
m_{i}^{t+1}=m_{i}^{t}+\left(1-m_{i}^{t}\right) s_{i}^{t+1}-m_{i}^{t} s_{j}^{t+1}, \quad i \neq j \text { and } t=0,1
$$

where $m_{i}^{t}$ is firm $i$ 's market share at the end of time $t$ and $s_{i}^{t+1}$ is its ability to grab rivals' market share during the round of competition at time $t+1(t=0,1)$. Here, $m_{1}^{0}=m$ and $m_{2}^{0}=1-m$. $s_{i}^{t+1}$ denotes the effectiveness of marketing efforts made by firm $i$ at time $t+1$. While firm $i$ can grab its competitor's time-t market share $\left(m_{j}^{t} \equiv 1-m_{i}^{t}\right)$ with intensity $s_{i}^{t+1}$, the other firm (firm $j$ ) can also attract customers away from firm $i$ at the same time. Thus its final market share depends on both players' relative marketing abilities.

To make the model realistic yet tractable, we assume that a public firm's ability to grab market share after its

\footnotetext{
${ }^{11}$ We assume a Cobb-Douglas type of production function to capture the idea that capital and market share are substitutes: the firm can increase profits either by selling more (if it has greater market share) or by producing more cheaply (which involves greater investment in capital). We adopt the above production function for analytical simplicity: adopting more complex production functions complicates our analysis considerably without changing our results qualitatively.

${ }^{12}$ The market share competition is a variant of the Lanchester (1916) battle model, which has been widely adopted in the marketing literature. Some recent finance papers such as Spiegel and Tookes (2006) also make use of this model to characterize product market competition.
} 
IPO is linear in its existing market share. Moreover, a private firm's ability to grab market share from competitors is normalized to be zero. Specifically, we assume:

$$
s_{i}^{t+1}=\left\{\begin{array}{l}
s m_{i}^{t}, \text { if firm } i \text { is public } \\
0, \quad \text { if firm } i \text { is private }
\end{array} \quad 0<s<1 .\right.
$$

Here, $s$ denotes the per-unit-market-share advantage that a public firm enjoys relative to a private firm in terms of product market competition. If firm $i$ goes public early (i.e. before the first round of competition at time 1 ), it can grab market share from firm $j$ for two rounds (at time 1 and 2). In other words, a late IPO may be costly due to the loss in market share at time $1 .^{13}$

If a firm wants to go public, it is better off doing so at time 1 rather than delaying it to time 2: in other words, there is a first-mover advantage from going public early. Let's use firm 1 as an illustration. If the final industry outcome is that both firms go public, then for firm 1, an IPO at time 1 weakly dominates an IPO at time 2 . This is due to the fact that going public at time 1 will give it an immediate competitive edge while deferring the IPO will result in a loss of this opportunity and may even subject the firm to more aggressive competition from the rival firm. Likewise, if the final industry outcome is that only firm 1 goes public, an IPO at time 1 is still weakly dominant. This means that the IPO decision at time 1 is a real option driven by both capital concerns and competitive forces. While deferring the IPO decision may save the firm the cost of going public if its productivity turns out not to increase and it is unnecessary for it to raise external financing, doing so may sacrifice the opportunity to enlarge its market share at an earlier date. As we will discuss in the next section, this trade-off prompts many firms to go public purely out of product market competition concerns and drives industry-wide IPO waves.

\section{Equilibrium}

The equilibrium concept we use is Perfect Bayesian Equilibrium (PBE). At time 1, both firms choose to either go public or remain private. If they go public at time 1 , they have no choice to make at time $2 .{ }^{14}$ Otherwise they can choose to go public at time 2 after observing the realization of the potential productivity shock. Therefore a PBE is

\footnotetext{
${ }^{13}$ The market-share grabbing technology that we postulate here does not allow a firm that goes public later (at time 2) to grab back some of the market share it lost to its public competitor in the previous period (when it was private). However, even if we allow the firm that goes public later to grab back some of the market share it lost to its competitor who went public early, our results will remain qualitatively unchanged as long as the firm going public earlier retains some of the "first-mover advantage" it gained by going public earlier even after its competitor goes public. As we illustrated through various anecdotes in the introduction (and document later in our empirical analysis), this seems to be consistent with practice, at least in many industries. Further, a large theoretical literature in industrial organization has demonstrated that first movers can obtain significant permanent advantages in the product market through a variety of mechanisms, three of which are leadership in product and process technology (e.g., Spence (1981)), preemption of scarce assets (e.g., Schmalensee (1978)), and development of buyer switching costs (e.g., Wernerfelt (1985)): see Lieberman and Montgomery (1988) for a review of this theoretical literature. Finally, a large empirical literature in industrial organization has documented that market pioneers can indeed develop first-mover advantages that span decades: see Robinson, Kalyanaram, and Urban (1994) for a review of this empirical literature.

${ }^{14} \mathrm{We}$ do not allow firms to go private once they have gone public. However, there will be no change in the equilibrium of our model even if we relax this assumption, since, once a firm has already incurred the cost $B$ of going public, it does not have any advantage from reverting back to become a private firm.
} 
a complete characterization of all contingent strategies of the two firms in the two periods. First, we will analyze the benchmark case where an IPO does not affect product market competition. We will then proceed to solve the full model where an IPO enhances a firm's competitiveness in the product market. Due to space considerations, in this section we confine ourselves to intuitive discussions of various equilibria and the situations where they arise. Formal propositions with proofs can be obtained from the Internet Appendix B available on the authors' websites or from the working paper version of this article.

\subsection{Benchmark case: IPO does not affect product market competition}

Given the level of newly raised capital, $E_{i}$, and the rational expectation of the firm's long-run market value, $E_{t}\left(V_{i}\right)$, the sharing rule between existing owners (insiders) and new shareholders during an IPO is determined as follows: the investors will acquire $E_{i} / E_{t}\left(V_{i}\right)$ fraction of the firm and the remaining shares belong to the existing owners. Thus, firm insiders will try to maximize the entire firm's market value (since their stake in the firm is $E_{t}\left(V_{i}\right)-E_{i}$ ) and will choose its optimal investment policy. We thus do not model any agency problems between insiders and outsiders. Insiders can choose to use only a fraction of the capital raised for investment in the firm. Further, unlike physical production which exhausts raw materials and other inputs, the capital used here is nonperishable. ${ }^{15}$ The firm will not use capital beyond the efficient level $\left(K_{i}^{e}\right)$, which in turn depends on its market share as well as its productivity at time 2. Depending on whether firm $i$ experiences the productivity shock at time $2, K_{i}^{e}$ can be either $m_{i}^{I I}\left(A_{i}^{I I}\right)^{\frac{1}{1-\gamma}}\left(\frac{c}{\gamma}\right)^{\frac{1}{\gamma-1}} \equiv m_{i}^{I} k_{i L}^{e}$ (without a productivity shock) or $m_{i}^{I I}\left(A_{i H}^{I I}\right)^{\frac{1}{1-\gamma}}\left(\frac{c}{\gamma}\right)^{\frac{1}{\gamma-1}} \equiv m_{i}^{I} k_{i H}^{e}$ (with a productivity shock), where $k_{i L}^{e}$ and $k_{i H}^{e}$ denote firm $i$ 's efficient level of capital per unit of market share without and with the productivity shock, respectively. For simplicity, we assume that $E_{1}=E_{2} \equiv E>\operatorname{Max}\left(k_{i H}^{e}-K_{0}, 0\right), \forall$ $i=1,2$. In other words, we assume that if either firm decides to go public, the amount raised is the same, and is large enough to meet the investment requirement of the higher productivity firm after a productivity shock. ${ }^{16}$ Since the investor's participation constraint has to be satisfied, the fraction of equity sold to new investors is $E / E_{t}\left(V_{i}\right)$. Once

\footnotetext{
${ }^{15}$ This assumption is innocuous. As long as the capital depreciation rate is the same for both firms, all our results are unaffected.

${ }^{16}$ The assumption that both high and low productivity firms raise the same amount of money in their IPOs can be endogenized in an asymmetric information setting where the precise productivity of firms (high versus low) is unobservable to outsiders, there are significant costs associated with making additional equity issues after the IPO, and the objective of firm insiders is to maximize the long-run value of their equity holdings in the firm. In such a setting, the market valuation of the equity of the two firms will be done in a pooling equilibrium, where the low productivity firm mimics the high productivity firm (otherwise the low productivity firm will reveal its type to outsiders and get a lower valuation). The high productivity firm will raise the amount of money needed for it to meet its investment requirements in the event of a productivity shock in full (it will not raise an amount smaller than that, since it will have to incur additional costs to make subsequent equity issues); neither will it raise a larger amount, since it wants to minimize the dilution in insider's equity holdings at the time of the IPO (recall that it will be undervalued in the pooling equilibrium). In such a scenario, both types of firms would raise the same amount of money in the IPO. See, e.g., Chemmanur (1993) for an IPO model with asymmetric information where higher and lower productivity (intrinsic value) firms raise the same amount of money in equilibrium. Since we adopt a reduced-form modeling approach here, we have chosen not to endogeneize the IPO amount raised by introducing asymmetric information into our setting, since this will add considerable complexity to our analysis. There is also some empirical support for the assumption that the amount raised in a firm's IPO is not directly related to its productivity. In an unreported empirical analysis, we find that the amount of money raised in the IPO by higher productivity firms (measured by total factor productivity or three-year average sales growth) does not significantly differ from that raised by lower productivity firms, after controling for firm size and stock market conditions. Moreover, we also find empirically that the amount of money raised in the IPO is not significantly different for firms going public within a wave versus outside a wave, and for firms going public early in a wave versus later in the wave.
} 
the firm goes public, the long-run (time 3) value of firm $i, V_{i}$, is given by $\left\{A_{i}^{I I}\left(m_{i}^{I I}\right)^{1-\gamma}\left(K_{i}^{e}\right)^{\gamma}-c K_{i}^{e}\right\}+K_{0}+E-B$.

Without product market concerns, a firm will go public if and only if its initial capital level $\left(K_{0}\right)$ is lower than its efficient level $\left(K_{i}^{e}\right)$ and the efficiency gain from raising new capital exceeds the cost of going public $B$. By examining the expression for efficient capital level, we have $K_{0}<K_{i}^{e} \Leftrightarrow A_{i}^{I I}>\left(c K_{0}^{1-\gamma}\right) /\left(\gamma\left(m_{i}^{I I}\right)^{1-\gamma}\right) \equiv \overline{A_{i}}$. Recall that firm 1 is assumed to have higher productivity. Without loss of generality, we further assume that the productivity shock raises firm 1's productivity above the threshold level $\left(\overline{A_{1}}\right)$ but not that of firm $2\left(\overline{A_{2}}\right)$. We make the following parametric assumption regarding the productivity levels of firms 1 and 2 with and without a productivity shock: ${ }^{17}$

$$
\left\{\begin{array}{l}
A_{2}<A_{1}<\frac{c K_{0}^{1-\gamma}}{\gamma}<\overline{A_{i}} \\
A_{2 H}<\frac{c K_{0}^{1-\gamma}}{\gamma}<\overline{A_{2}} \\
A_{1 H}>\frac{c K_{0}^{1-\gamma}}{\gamma\left[m_{c}-s m_{c}\left(1-m_{c}\right)\right]^{1-\gamma}} \geq \overline{A_{1}}
\end{array}\right.
$$

Given the above assumption, both firms are able to operate at their optimal scale if they do not experience a productivity shock, whether or not they go public. Likewise, firm 2 will always be able to use its efficient level of capital whether or not its productivity increases. However, firm 1 will need new capital after experiencing a productivity shock if it is to operate at its efficient scale, though it may also choose to remain private (and operate at an inefficient scale) if the cost of going public is too large. Lastly, to make the model interesting, we also assume that the cost of going public $B$ is not too large so that firm 1, upon the realization of the productivity shock, will choose to go public even if doing so results in no additional market share. ${ }^{18}$

In the above setting, where going public does not enhance a firm's market-share-grabbing ability (i.e. $s=0$ for both public and private firms), neither firm goes public in equilibrium without a productivity shock. Further, even with a productivity shcok, the lower productivity firm 2 will never go public. Finally, the higher productivity firm 1 will go public if (and only if) there is a productivity shock, driven only by the need to raise additional external financing. The benchmark case thus predicts no IPO waves (or hot-issuing periods) in the absence of product market competition (we define an IPO wave in our model to be the situation where both firms go public either at time 1 or time 2 , so that by the end of the game both are public).

\footnotetext{
${ }^{17}$ Note that this assumption is not as restrictive as it appears. The crucial assumption here is that firm 1 has higher productivity ex ante than firm 2. The assumption that firm 1 needs new capital after the productivity shock whereas firm 2 does not (even after the productivity shock) can be relaxed without affecting the central intuition of the paper, although such relaxation may lead to uninteresting equilibria where both firms always want to go public at time 1 or to remain private during both periods.

${ }^{18}$ This assumption is not unduly restrictive, since it simply requires that, if external financing is required, then the cash flow benefits to firm 1 of raising such external financing by going public dominates the cost of doing so, even in absence of any product market benefits from going public.
} 


\subsection{Full Model: IPO enhances product market competitiveness}

In this section, we assume that going public not only provides necessary funding to firms, but also enhances their competitiveness in the product market. Without a productivity shock, a firm's benefit from going public purely comes from an IPO's enhancement in its competitiveness in the product market. We assume that the fixed cost of going public, $B$, exceeds these additional benefits from going public in the absence of a productivity shock. Thus, both firms will optimally choose to remain private without a productivity shock. ${ }^{19}$

At time 1, the two firms, under the common belief that a productivity shock may take place in the future with probability $p>0$, consider their going public decision. We assume that the productivity shocks are industry-wide (perfectly correlated), which means that with probability $p$, both firm 1 and firm 2 will experience an increase in productivity at time 2 and with probability $1-p$ they will not. ${ }^{20}$

Unlike in the benchmark setting, in this full fledged model firm 1 has two incentives to go public: in addition to the benefit of raising capital that it needs to operate at its optimal scale in the event of a productivity shock, going public now has the additional benefit of increasing firm 1's ability to grab market share from its competitor. Knowing that firm 1 may go public, firm 2 may also wish to go public (even though it does not need to raise any additional capital if a productivity shock is realized), since staying private will put it in a much worse product market position. This strategic concern of firm 2 gives firm 1 an additional incentive to go public even at time 1 when the actual productivity shock is not realized. Of course, to obtain the above benefits from going public, either firm has to incur the deadweight cost of going public. For either firm, the trade-off between going public early (at time 1) versus late (at time 2) is as follows. The advantage of going public early is that the firm is able to grab market share from the competing firm (and to prevent the other firm from grabbing market share from it) in two rounds of product market competition. The disadvantage of going public early is that it incurs the cost of going public before it knows for sure whether a productivity shock is realized (so that the firm may end up being public in a situation where no shock is realized, and it would have been better off remaining private). The benefit of going public early versus late is always greater for firm 1 than for firm 2 (since it has multiple reasons for going public, while firm 2 has only the benefit of grabbing market share); on the other hand, the cost of going public is the same for both firms. Therefore, with product market competition, both firms may go public around the possible arrival of a productivity shock, potentially creating an IPO wave that would not happen in the benchmark case. Depending on whether or not an IPO wave is generated (i.e., both firms go public) and the timing of their going public, there are five possible equilibria, which we discuss in detail in the next section.

\footnotetext{
${ }^{19}$ This assumption is not crucial for the intuition behind our results to go through, but is made only for analytical tractability.

${ }^{20} \mathrm{We}$ have also analyzed the scenario where either firm's productivity shock is purely idiosyncratic. Most of our results remain qualitatively unchanged even in this case. These results are available from the authors upon request.
} 


\subsubsection{Description of Equilibria and Intuition}

There are a total of five possible Perfect Bayesian Equilibria (PBEs) in this game, which are summarized in Figure $2:^{21}$

\begin{tabular}{|c|c|c|c|c|}
\hline \multirow[b]{2}{*}{ Magnitude of Shock } & \multicolumn{4}{|c|}{ Market Share Distribution (Firm I's Market Share) } \\
\hline & $\begin{array}{c}\text { Small } \\
\left(m \leq \frac{2+s-\sqrt{s^{2}+4}}{2 s}\right)\end{array}$ & $\begin{array}{c}\text { Moderate } \\
\left(\frac{2+s-\sqrt{s^{2}+4}}{2 s}<m<\frac{1}{2}\right)\end{array}$ & $\begin{array}{c}\text { Large } \\
\left(\frac{1}{2} \leq m<\frac{s-2+\sqrt{s^{2}+4}}{2 s}\right)\end{array}$ & $\begin{array}{c}\begin{array}{c}\text { Very Large } \\
\left(m \geq \frac{s-2+\sqrt{s^{2}+4}}{2 s}\right)\end{array} \\
\end{array}$ \\
\hline $\begin{array}{l}\text { Very Large } \\
\left(\Delta A \geq \Delta A_{H}\right)\end{array}$ & $\mathrm{Eq} 1, \mathrm{Eq} 2, \mathrm{Eq} 3$ & $\mathrm{Eq} 1, \mathrm{Eq} 2, \mathrm{Eq} 3$ & $\mathrm{Eq} 1, \mathrm{Eq} 2, \mathrm{Eq} 3$ & $\mathrm{Eq} 1, \mathrm{Eq} 2, \mathrm{Eq} 3$ \\
\hline $\begin{array}{c}\text { Large } \\
\left(\Delta A_{L} \leq \Delta A<\Delta A_{H}\right)\end{array}$ & $\mathrm{Eq} 1, \mathrm{Eq} 3, \mathrm{Eq} 4$ & $\mathrm{Eq} 1, \mathrm{Eq} 2, \mathrm{Eq} 5$ & $\mathrm{Eq} 1, \mathrm{Eq} 2, \mathrm{Eq} 5$ & $\mathrm{Eq} 1, \mathrm{Eq} 2, \mathrm{Eq} 5$ \\
\hline $\begin{array}{c}\text { Moderate } \\
\left(A_{1}-A_{2}<\Delta A \leq \Delta A_{2}\right)\end{array}$ & $\mathrm{Eq} 1, \mathrm{Eq} 4, \mathrm{Eq} 5$ & $\mathrm{Eq} 1, \mathrm{Eq} 4, \mathrm{Eq} 5$ & $\mathrm{Eq} 1, \mathrm{Eq} 4, \mathrm{Eq} 5$ & $\mathrm{Eq} 1, \mathrm{Eq} 4, \mathrm{Eq} 5$ \\
\hline $\begin{array}{c}\text { Small } \\
\left(\Delta A \leq A_{1}-A_{2}\right)\end{array}$ & $\mathrm{Eq} 4, \mathrm{Eq} 5$ & $\mathrm{Eq} 4, \mathrm{Eq} 5$ & $\mathrm{Eq} 4, \mathrm{Eq} 5$ & $\mathrm{Eq} 4, \mathrm{Eq} 5$ \\
\hline \multicolumn{5}{|c|}{$\begin{array}{l}\text { Eq1: both firms go public at time } 1 \text {. } \\
\text { Eq2: both firms remain private at time } 1 \text { and go public only upon the realization of a shock at time } 2 \text {. } \\
\text { Eq3: firm } 1 \text { goes public at time } 1 \text { and firm } 2 \text { goes public only upon the realization of a shock at time } 2 \text {. } \\
\text { Eq4: firm } 1 \text { goes public only upon the realization of a shock at time } 2 \text { and firm } 2 \text { remains private throughout } \\
\text { Eq5: firm } 1 \text { goes public at time } 1 \text { and firm } 2 \text { remains private throughout. }\end{array}$} \\
\hline
\end{tabular}

Figure 2: Distribution of Possible Equilibria over Different Parameter Ranges

Eq1 refers to the PBE where IPO waves occur even without a productivity shock. When the magnitude of the shock is moderate $\left(A_{1}-A_{2}<\Delta A \leq \Delta A_{L}\right)$, the probability of the shock is large, the cost of going public is small, and the existing productivity levels of firm 1 and firm 2 are high, both firms will go public before the realization of a productivity shock (at time 1). The intuition here is straightforward: when both firms' existing productivity levels are high (close to the threshold level $\overline{A_{i}}$ ), a highly probable industry-wide shock with a moderate magnitude is very likely to render the firms' current production scales inefficient, making firm 1 eager to obtain fresh capital through an IPO. Since the productivity shock is likely and both firms are close to their efficient operating scales, firm 2 knows for sure that firm 1 will go public by the end of the game (by conducting its IPO at time 1 or 2 ), which means that if it does not go public, it will lose market share at least in the second round of product market competition. The benefit of additional market share depends on the magnitude of each firm's productivity level. Hence, the high existing productivity level of firm 2 makes it care much about the potential loss of market share due to firm 1's strengthening competitive position after the IPO. When this potential loss exceeds the cost of going public, firm 2 will go public. Inferring this, firm 1's incentive to go public is also enhanced. The cost to firm 1 from going public at time 1 is that it wants to avoid paying an "unnecessary" cost of going public should the shock not be realized at time 2. Therefore, when the cost of going public is considerably smaller than the expected gain in profits (due to its high existing productivity) and given its conjecture about firm 2's aggressive going-public strategy, firm 1 will be

\footnotetext{
${ }^{21}$ Note: the definitions of $\Delta A_{L}$ and $\Delta A_{H}$ are given in the Internet Appendix B available on the authors' websites or from the working paper version of this article.
} 
prompted to go public at time 1 itself, even without the realization of a productivity shock. Knowing this, firm 2 will also go public at time 1 to combat firm 1 in the product market as early as possible. Consequently, both firms end up going public at time 1, creating an IPO wave even before the realization of the productivity shock.

Eq2 and Eq3 refer to PBEs where IPO waves occur only after a productivity shock. When the magnitude of a potential shock is large $\left(\Delta A>\Delta A_{L}\right)$, in addition to Eq1, we have two more equilibria. When the existing market share of firm 1 is moderately large $\left(m \geq\left(2+s-\sqrt{s^{2}+4}\right) /(2 s)\right)$, and the existing productivity levels of firm 1 and firm 2 are low, both firms will remain private before the realization of a productivity shock (at time 1) and go public only upon the realization of a shock (at time 2). This is Eq2. When the existing market share of firm 1 is small $\left(m<\left(2+s-\sqrt{s^{2}+4}\right) /(2 s)\right)$, the existing productivity of firm 1 is high, and the existing productivity of firm 2 is low, firm 1 will go public before the realization of a productivity shock (at time 1) and firm 2 will go public only upon the realization of a shock (at time 2). This is Eq3.

If the existing market share of firm 1 is small enough $\left(m<\left(2+s-\sqrt{s^{2}+4}\right) /(2 s)\right)$, Eq2, rather than Eq3, will occur when the other parametric conditions specified above are met. The intuition is as follows. The additional market share each firm can gain by product market competition depends on two things: the available market share to grab from rivals (i.e. rivals' existing market share), and its own market-share-grabbing ability, which in turn depends on its own existing market share. When firm 1's existing market share is much smaller than that of firm 2, the latter's gain in market share by going public at time 2 would be larger if firm 1 goes public at time 1 compared to the case where firm 1 goes public only upon the realization of the productivity shock (at time 2). The reason is that when firm 1 is currently a small player in the product market, firm 2, despite its strong market-share-grabbing ability, has little to grab by going public, so that its gain from an IPO is small. On the other hand, when firm 1 goes public at time 1, its market share will increase in the first round of product market competition, which in turn increases firm 2's incentive to compete for market share in the second round of competition. Thus, firm 2's incentive to go public at time 2 will be stronger if firm 1 goes public at time 1 than if firm 1 delays its IPO decision. When firm 1's existing market share is larger than $\left(2+s-\sqrt{s^{2}+4}\right) /(2 s)$ and the magnitude of a potential shock $\Delta A$ is between $\Delta A_{L}$ and $\Delta A_{H}$, the benefit of firm 2's going public upon a productivity shock dominates its cost of going public if firm 1 remains private at time 1, but is less than its cost of going public if firm 1 chooses to go public one period earlier. Thus Eq2 cannot occur whereas Eq3 can. When the magnitude of the productivity shock is very large $\left(\Delta A>\Delta A_{H}\right)$, both Eq2 and Eq3 will exist since the initial market share distribution between the two firms does not matter in determining the equilibrium.

Apart from the existing market share distribution, the difference in the two firms' existing productivity levels also determines which PBE will occur when the magnitude of the shock is at least $\Delta A_{L}$. Note that in both Eq2 and Eq3, the existing productivity of firm 2 is so low that it has no desire to go public before a productivity shock is realized. When the existing productivity of firm 1 is high, it has a strong incentive to go public earlier (i.e. at time 1) because 
each unit of additional market share gained through more effective product market competition will bring it larger time 3 cash flows. This leads to Eq3, the most interesting "sequential IPO wave equilibrium". On the other hand, if the existing productivity level of firm 1 is also low (as that of firm 2), it will also choose to wait until the realization of a productivity shock because the marginal benefit of additional market share gained by going public earlier does not outweigh the cost of going public. In this scenario, we will observe Eq2, where both firms adopt exactly the same strategy: remain private at time 1 and go public if and only if the productivity shock occurs at time 2 .

Eq4 and Eq5 refer to the PBEs where IPOs only occur off the wave. When the magnitude of a potential productivity shock is not too large $\left(\Delta A<\Delta A_{H}\right)$, we have these two equilibria in addition to the above three PBEs. When the probability of a potential shock is low, the existing market share of firm 1 is small $(m<(2+s-$ $\left.\sqrt{s^{2}+4}\right) /(2 s)$ ), the existing productivity of firm 1 is low, and the cost of going public is large, firm 1 will go public only upon the realization of a shock (at time 2) and firm 2 will remain private throughout. This is Eq4. When the probability of a potential productivity shock is high, the existing market share of firm 1 is moderately large $\left(m \geq\left(2+s-\sqrt{s^{2}+4}\right) /(2 s)\right)$, the existing productivity of firm 1 is high, and the cost of going public is small, firm 1 will go public before the realization of a productivity shock (at time 1) and firm 2 will remain private throughout. This is Eq5.

In both Eq4 and Eq5, firm 2 will remain private throughout the two periods because its marginal cash flow benefit from additional market share gained by going public is too small compared to the cost of going public. Even though a productivity shock may improve its productivity at time 2, firm 2's incentive to go public is still small as the shock is not large enough to make it go public after taking into account the cost involved. Hence, the only difference between Eq4 and Eq5 is the timing of firm 1's going public. Eq4 will exist if the cost of going public is very large, and when the existing productivity level of firm 1 is low. Eq5 will exist when the cost of going public is not too large and the existing productivity level of firm 1 is high. In this case, firm 1 has a stronger incentive to go public earlier and grab market share from firm 2. Similar to the case of Eq2 and Eq3, the existing market share distribution affects the occurrence of Eq4 versus Eq5 when $\Delta A_{L}<\Delta A<\Delta A_{H}$.

It is useful to understand why the probability of a potential productivity shock, $p$, influences the occurrence of various equilibria. Its effect on Eq1 is clear: if $p$ is larger, both firms will be more likely to go public at time 1 . This is because given the rival firm going public at time 1, there is no uncertainty with respect to the rival's strategy at time 2, so each firm's benefit of going public earlier (at time 1) purely depends on the probability of getting a productivity shock. Even firm 2's incentive to go public increases with $p$, since the shock is large enough to make the additional market share gained from going public early profit-enhancing. The effect of $p$ on the occurrence of Eq4 and Eq5 is also clear: when $p$ is larger, firm 1 will be more likely to benefit from the additional market share grabbed from firm 2 if it goes public at time 1. Firm 2 will remain private throughout in both these equilibria (because its benefit of going public is too small compared to the cost of going public), so that firm 1 does not have to be concerned about 
the possible loss of market share due to firm 2's going public at time 2. Thus, its incentive to go public at time 1 monotonically increases with $p$. When $p$ is large, we are more likely to observe Eq4, whereas a small $p$ leads to Eq5. ${ }^{22}$

\section{Implications and Testable Hypotheses}

By inspecting the five possible PBEs above, we can see that an IPO wave (defined as both firms going public, either at time 1 or time 2) can result from Eq1, Eq2, and Eq3, and that stand-alone IPOs can happen in Eq3, Eq4, and Eq5. ${ }^{23}$ Under all circumstances, the lower-productivity firm (firm 2 here) never goes public alone, but rather conducts its IPO either following or at the same time as its higher-productivity rival (firm 1). This leads to the implication that in general, stand-alone IPOs are conducted only by higher-productivity firms, but IPOs in an IPO wave involve both high and low productivity firms. The intuition here is simple: besides product market concerns, higher productivity firms need more capital to approach their efficient operating scales. They therefore have much stronger incentives to go public than lower-productivity firms who merely go public under pressure from product market competition. Hence, higher-productivity firms will go public even when doing so does not bring any additional market share. The same intuition also leads to the implication that everything else equal, firms going public in an IPO wave will, on average, have lower post-IPO operating performance than firms going public off the wave. This is because if two firms in an industry having an identical initial capital level $\left(K_{0}\right)$ raise the same amount of equity $(E)$ and have the same post-IPO market share $\left(m_{i}^{I I}\right)$, then the higher productivity firm will also have better post-IPO operating performance. In summary, our model predicts that, on average, firms going public outside an IPO wave (i.e. in a cold market) will have higher productivity $\left(\mathbf{H}_{3}\right)$ and better post-IPO profitability $\left(\mathbf{H}_{5}\right)$ than those going public within an IPO wave.

We do not have an equilibrium in which firm 2 goes public at time 1 and firm 1 follows suit at time 2 (thus creating a "sequential IPO wave"). In fact, as we have discussed in the last section, firm 2 will never go public alone at time 1. Eq3 is the only equilibrium that may generate an IPO wave that spans both time 1 and 2 , given that an industry-wide productivity shock actually takes place. The intuition why firms with superior pre-IPO productivity are more eager to go public early on in a given wave is as follows. Both types of firms need to evaluate the benefits and costs of waiting to go public. On the one hand, the cost of waiting, which is the loss of the opportunity to gain market share, is larger for the higher-productivity firm 1, due to its superior cash-flow generating ability per unit of market share. On the other hand, the benefit of waiting until time 2, which arises from being able to avoid

\footnotetext{
${ }^{22}$ The effect of $p$ on the occurrence of Eq2 and Eq3, however, is ambiguous. For these two equilibria to be possible, the magnitude of the shock must be large enough so that firm 2, in addition to firm 1, will also find it desirable to go public at time 2 if the shock is realized. The difference between the two equilibria is firm 1's choice of IPO timing. On the one hand, a higher $p$ gives firm 1 stronger incentives to go public at time 1 because it knows there is a bigger chance that it will need additional capital after the shock occurs. This concern tends to make Eq3 more likely than Eq2. On the other hand, a higher $p$ means that firm 2 is also more likely to go public at time 2 when the shock is realized, reducing the additional market share that firm 1 expects to grab by going public before the shock is actually realized (at time 1). Given this, firm 1 may wish to delay its IPO decision until time 2, leading to Eq2.

${ }^{23} \mathrm{Eq} 3$ may involve an IPO wave (if a productivity shock is realized) or only one firm (firm 1) going public (if the shock is not realized).
} 
incurring the cost of going public unnecessarily if the productivity shock does not take place, is larger for firm 2 (the lower-productivity firm), since its only benefit of going public comes from considerations of product market competition (recall that firm 2 does not need additional capital to operate at its optimal scale). Whether or not the productivity shock occurs, firm 2 does not need extra capital for production, so that if it goes public at time 1, it pays the cost of going public only for product market reasons. In summary, the expected cost of going public "unnecessarily", arising from the scenario where the firm goes public early (at time 1) but a productivity shock is not realized at time 2, is bigger for firm 2, which implies that the benefit of waiting is also larger for lower-productivity firms. Comparing both the costs and benefits of waiting for the two types of firms will give rise to the prediction that firms with higher pre-IPO productivity will go public earlier within an IPO wave. This fact also means that these (higher productivity) firms that go public earlier in an IPO wave will perform better after the IPO than those that go public later in the wave, if they have the same level of post-IPO capital stock and market share. Thus, our model predicts that everything else equal, a firm that goes public earlier in an IPO wave will have higher post-IPO operating performance on average than a firm that goes public later in the wave. In summary, our model predicts that, on average, firms going public earlier in an IPO wave will have higher productivity $\left(\mathbf{H}_{4}\right)$ and better post-IPO profitability $\left(\mathbf{H}_{6}\right)$ than those going public later in the wave.

Since higher-productivity firms in general need more capital for expansion, our next hypothesis $\left(\mathbf{H}_{7}\right)$ is that controlling for the total amount of proceeds raised, firms going public in an IPO wave will on average hold more cash on hand (or use less of the amount raised through their IPO) than firms going public off the wave. Similarly, we have the hypothesis $\left(\mathbf{H}_{8}\right)$ that controlling for the total amount of proceeds raised, firms going public earlier in an IPO wave will on average hold less cash on hand (or use more of the cash raised through their offerings for investment) than firms going public later in the wave. The above two predictions arise from our assumption that both high and low productivity firms raise the same amount of money in the IPO. Since higher productivity firms have a larger optimal scale (investment requirement) than lower productivity firms, they are left with less cash after investing in their projects than lower productivity firms. As we discuss in section 3 (footnote 16), this assumption can be endogenized in a setting of asymmetric information where only firm insiders can observe the true productivity of a firm and there are significant transaction costs to making additional equity issues after the IPO. ${ }^{24}$

The predictions of our model regarding the effect of industry concentration on the pre-IPO productivity and post-IPO profitability of firms going public on the wave versus off the wave and earlier in the wave versus later in the wave are ambiguous. On the one hand, for an industry characterized by a few large players (high concentration),

\footnotetext{
${ }^{24}$ Note also that the above two predictions can be generated even in the absence of the assumption that the IPO amount raised by the two kinds of firms are the same, as long as the IPO amount raised by both firms is greater than their optimal investment requirement, and this difference between the IPO amount raised and the optimal investment requirement is proportionately greater for low productivity firms than for high productivity firms. The latter condition is likely to hold as long as there are significant economies of scale in raising external financing in an IPO, which seems to be the case in practice: see, e.g., Ritter (1987), who documents that the cost of going public is significantly larger (as a proportion of the IPO amount raised) when the IPO issue amount is smaller.
} 
any competitor's IPO will exert a large product market pressure on the rest of the firms in the industry, which may then go public, thereby creating an IPO wave. This leads to the prediction that greater industry concentration will amplify the difference in post-IPO operating performance for firms going public on the wave versus those going public off the wave, and between those going public earlier in a wave versus those going public later in the wave. On the other hand, it may be the case that larger firms that already have significant market share in an industry as private firms do not have too much to gain by going public. This is because such firms already have considerable credibility with potential employees, customers, and suppliers even as private firms. In this case, firms in more concentrated industries will be less likely to go public out of product market concerns, attenuating the above difference. In sum, the effect of industry concentration on the difference in post-IPO operating performance for firms going public on the wave versus off the wave and earlier in a wave versus later in the wave is an empirical question, and will be the ninth hypothesis $\left(\mathbf{H}_{9}\right)$ we test in our empirical analysis.

Before we test the above predictions of our model, we will first present some evidence regarding the important assumption we make in our model that IPO firms can grab additional market share from their competitors (especially private competitors). Our objective here is not to show causality, but to analyze the relation between a firm going public and its subsequent market share. Thus, our first hypothesis $\left(\mathbf{H}_{1}\right)$ is that going public will be associated with a significant increase in an IPO firm's market share. Our second hypothesis $\left(\mathbf{H}_{2}\right)$ is that IPOs in an industry will be associated with a reduction in the market share of same-industry competitors, and this negative correlation will be larger for competitors that are private.

\section{$5 \quad$ Data and Sample Selection}

The data used in this study mainly comes from three sources. We obtain our overall IPO sample consisting of 6647 IPO firms from the Thomson Financial Securities Data Corporation (SDC) new issues database. We obtain the data required to calculate the total factor productivity (TFP) and the market share of firms remaining private as well as those going public (or are already public) from the LRD of the U.S. Census Bureau. Finally, we obtain data on the accounting performance of IPO firms subsequent to going public like ROA and cash holdings from the Compustat database. We test our first four hypotheses $\left(\mathbf{H}_{1}\right.$ to $\left.\mathbf{H}_{4}\right)$ regarding market share and TFP by using the Longitudinal Research Database (LRD) of the U.S. Census Bureau, which provides plant level information for all public and private firms in the manufacturing sector. We test our next five hypotheses $\left(\mathbf{H}_{5}\right.$ to $\left.\mathbf{H}_{9}\right)$ regarding post-IPO profitability by using the overall IPO sample from SDC (which includes all industries) merged with Compustat and a number of other data sources (to be explained in depth below).

We obtain our initial IPO sample from the Thomson Financial Securities Data Corporation (SDC) new issues database. We exclude from our initial IPO sample spin-offs, ADRs, unit offerings, reverse LBOs, foreign issues, 
REITS, close-end funds, offerings in which the offer price is less than $\$ 5$, finance and utilities (with Fama French 49 industry code 31, 45, 46, and 48), and those offerings whose industries are unidentified (with Fama French 49 industry code 49 or missing). ${ }^{25}$ To minimize the effect of wrong data entries on our study, we corrected for several mistakes and typos in SDC's database following Jay Ritter's "Corrections to Security Data Company's IPO database" (http://bear.cba.ufl.edu/ritter/ipodata.htm). ${ }^{26}$ Thus, our final sample contains 6647 IPOs between 1970 and 2006. We then extract financial statement information for the IPO firms in our sample from Standard \& Poor's Compustat files, stock price and shares outstanding data from CRSP, institutional investors' positions in new stocks from the Thomson Financial $13 f$ Institutional Holdings database, and IPO firms' founding years as well as their underwriter reputation from Jay Ritter's database. Due to missing observations for various variables, we may lose up to $55 \%$ of the sample when we conduct our empirical analysis (depending on the specification).

To examine the first four hypotheses regarding market share and TFP, we make use of the Longitudinal Research Database (LRD), maintained by the Center for Economic Studies at the U.S. Bureau of Census. The LRD is a large micro database which provides plant level information for firms in the manufacturing sector (SIC codes 2,000 to 3,999). In the census years $(1972,1977,1982,1987,1992,1997)$, the LRD covers the entire universe of manufacturing plants in the Census of Manufacturers (CM). In non-census years, the LRD tracks approximately 50,000 manufacturing plants every year in the Annual Survey of Manufacturers (ASM), which covers all plants with more than 250 employees. In addition, it includes smaller plants that are randomly selected every fifth year to complete a rotating five year panel. Therefore, all U.S. manufacturing plants with more than 250 employees are included in the LRD database on a yearly basis from 1972 to 2000, and smaller plants with fewer than 250 employees are included in the LRD database every census year and are also randomly included in the non-census years, continuously for five years, as a rotating five year panel. ${ }^{27}$ Most of the data items reported in the LRD (e.g., the number of employees, employee compensation, and total value of shipments) represent items that are also reported to the IRS, thus increasing the accuracy of the data.

We use the LRD data to examine private and public firms' market share based on their sales (total value of shipments) and to construct productivity measures such as the total factor productivity (TFP), which will be described in detail later. To match our sample of IPO firms and the LRD data, we require that the IPOs take place between 1972 and 2000 and that the primary industry of the firm going public is within the manufacturing sector (SIC codes 2000 to 3999). We also require that the IPO firm is present on Compustat for the fiscal year of the IPO. Then we

\footnotetext{
${ }^{25}$ The definition of Fama French 49 industries (based on 4-digit historical SIC codes) is obtained from Ken French's website (http://mba.tuck.dartmouth.edu/pages/faculty/ken.french/data_library.html).

${ }^{26}$ Moreover, due to duplicated entries, we checked Factiva and modified the observation for Wynn Resorts Ltd (CUSIP "983134", issue date "Oct. 25, 2002") whose proceeds and shares offered should be the sum of two entries in the database: "449.8" and "34.6 million", respectively.

${ }^{27}$ Given that a random sample of smaller plants is continuously present in our sample, our data is not substantially skewed towards larger firms; smaller firms are well represented in the data. The rotating sample of smaller plants is sampled by the Census Bureau each year in the non-census years in order to minimize such a bias in the data.
} 
match this sample of IPO firms to the LRD using the LRD-COMPUSTAT bridge file for a span of five years around the IPO date. In addition, we also identified all public firms (as defined by CRSP), i.e., firms that had an IPO prior to the start of our sample period (1972), in the LRD by using the same approach. For an industry-wise distribution of LRD firms going public, see Chemmanur, He, and Nandy (2010).

\section{Construction of Variables and Summary Statistics}

\subsection{Definitions of IPO Clusteredness and IPO Waves}

To compare the productivity and post-IPO operating performance of on-the-wave IPO firms versus off-the-wave ones in the same industry, we define the clusteredness ("hotness") of a certain industry's IPO market for the period within which a firm goes public. For each IPO in the sample, we count the total number of IPOs in the same FF-49 industry within a 90-day window symmetrically surrounding the issuance date for the given IPO and use this number $(I P O N U M)$ as a raw measure of the clusteredness of the IPO market in that industry for the particular issuance date under consideration. We also use two refinements for this raw measure (IPONUM). First, to control for the relative frequency of IPOs across different industries, we deflate IPONUM by the total number of IPOs over the entire sample period in the same industry as the particular IPO under consideration (IPONUM/Same Industry Vol.). Second, to control for overall hotness of the IPO market such as in a stock market boom, we deflate IPONUM by the total number of IPOs done in all industries within the same 90-day window surrounding that particular issue date (IPONUM /Same Window Vol.). ${ }^{28}$

To compare the productivity and post-IPO operating performance of firms going public early versus late in an IPO wave for a particular industry, we first identify and define IPO waves and then rank the IPOs in our sample within each wave by the order of their issuance dates. Using a procedure similar to that of Helwege and Liang (2004) as well as Pastor and Veronesi (2005), we first compute the three-month moving averages of IPO volume in a particular industry for each month. ${ }^{29}$ Then we define "hot periods" as those in which the moving average falls into the top quartile of that industry's IPO months. Lastly, we define IPO waves as all sequences of consecutive "hot periods" that begin and end with non-zero number of issuances. To minimize the possibility of misclassifying concurrent stand-alone IPOs as a tiny wave (such as those waves consisting of only two offerings), we reclassify IPO waves by dropping those with a total number of four offerings or lower. ${ }^{30}$ Once the waves are defined, we then

\footnotetext{
${ }^{28}$ Alternatively, one can do the two deflations by using the number of new business formations gathered from Dun and Bradstreet (Helwege and Liang 2004) or the number of outstanding public firms in that industry one day before the issuance date (Lowry 2003 and Pastor and Veronesi 2005).

${ }^{29}$ It is worth emphasizing that our definition of IPO waves is based on a specific industry, unlike Pastor and Veronesi (2005), who use an IPO market-wide definition. However, given that we are testing a theory which is based explicitly on competition between firms in an industry, it seems to be quite appropriate in our case to use an industry-specific definition of waves.

${ }^{30}$ We have repeated our analysis by either keeping all of the originally defined IPO waves (with number of offerings within a wave greater than or equal to two) or using a stricter filtering rule by dropping all waves with number of IPOs fewer than ten. All our results are qualitatively similar.
} 
identify how early a firm goes public in a particular wave according to its issuance date. If more than one IPOs take place on the same date, we rank these IPOs according to their filing dates (if possible) or we randomize if the filing dates are missing (there are 32 such cases). A naive measure of how early an IPO takes place in a wave is just the order of that IPO's appearance within its wave $(O R D E R)$. However, this measure has two limitations. First, waves with a larger size will carry an undue weight in our analysis. For example, the last IPO in a wave with five offerings will get " $5 "$ as its score for ORDER whereas the last IPO in a wave with fifty offerings will get "50", even though they are both the last one in a given wave. Second, the relationship between post-IPO operating performance (or other accounting measures) and ORDER may not be linear, especially considering the fact that ORDER can only take positive integer values that can be as huge as 300: those extremely large integers will be unduly influential in our regression analysis. In light of the above two limitations, we use three refinements to ORDER in our analysis. First, to make this measure robust to the size of a wave and to control for the possible nonlinear relationship between post-IPO operating performance and ORDER, we chop ORDER for a given wave into four quartiles and assign "0", "1", "2", and "3" to each of them with larger numbers meaning later appearance in a wave. We call this measure EARLINESS. Second, to make the measure comparable across all waves, we divide ORDER by the median of it for a given wave (ORDER / Median ORDER) so that the order measure for all waves will be centered around 1 and have an approximate range between 0 and 2. Third, to control for the possible concave relationship between post-IPO variables and ORDER, we take the natural logarithm of ORDER and use it (Log (ORDER)) as a crude measure of how early a firm goes public within a hot-issue market.

\subsection{Definitions of Variables for Tests of Hypotheses $\boldsymbol{H}_{1}$ to $\boldsymbol{H}_{4}$}

We test our first four hypotheses $\left(\mathbf{H}_{1}\right.$ to $\left.\mathbf{H}_{4}\right)$ by using the LRD, thus focusing on the IPOs of manufacturing firms. To test the first two hypotheses, we construct measures for market share growth, fraction of IPO firms within an industry, and an IPO dummy. More specifically, the 1-year market share growth is the difference between the log market share in the next year and the current log market share (based on firm sales in the FF-49 industry). The 3-year market share growth is the difference between the log market share three years later and the current log market share. IPO Fraction is the total number of IPOs in the current year divided by the total number of firms (both public and private) in the same FF-49 industry in the same year. The reason we scale the total number of IPOs by the total number of firms is that we want to rule out the possibility that the reduction in market share is actually due to more firms in the industry (hence a higher level of competition) rather than due to more firms going public (more IPOs). IPO is a dummy that equals one if the firm went public in the current year, and equals zero otherwise.

We also measure other control variables by using information within the LRD database. Log (capital stock) is the 
natural logarithm of firm capital stock in thousands of dollars in the current year, where capital stock is constructed via the perpetual inventory method and is the sum of building assets plus machinery assets. Log (age) is the number of years since the birth of the first plant of the firm as recorded in the Census data. Sales growth is the average growth in sales in the past three years. Market share is a firm's current-year market share within the FF-49 industries based on all LRD firms' sales. Capex Ratio is capital expenditure over capital stock. Venture Capital is a dummy that equals one if the firm is backed by venture capitalists.

To test the third and fourth hypotheses, we construct our measure for firm productivity, total factor productivity (TFP). We first calculate TFP for each individual plant at the annual four digit (SIC) industry level using the entire universe of plants in the LRD as in previous literature (see, e.g., Chemmanur, He, and Nandy (2010)). The total factor productivity of the firm is then calculated as a weighted sum of plant Total Factor Productivities (TFP) at the annual level. In particular, we obtain measures of TFP at the plant level by estimating a log-linear Cobb-Douglas production function for each industry and year. Industry is defined at the level of four-digit SIC codes. Individual plants are indexed $i$; industries $j$; for each year $t$, in the sample. Plant level TFP is computed as the residuals of regression (5), estimated separately for each year and each four-digit SIC industry. ${ }^{31}$

$$
\ln \left(Y_{i j t}\right)=\alpha_{j t}+\beta_{j t} \ln \left(K_{i j t}\right)+\gamma_{j t} \ln \left(L_{i j t}\right)+\delta_{j t} \ln \left(M_{i j t}\right)+\varepsilon_{i j t}
$$

Since the above regressions include a constant term, TFP only contains the idiosyncratic part of plant productivity. Output (Y) is constructed as plant sales (total value of shipments in the LRD) plus changes in the value of inventories for finished goods and work-in-progress. Since we appropriately deflate plant sales by the annual industry specific price deflator, our measure is proportional to the actual quantity of output. Thus, the dispersion of TFP for firms in our sample almost entirely reflects dispersions in efficiency.

Labor input (L) is defined as production worker equivalent man hours. This is the product of production worker man-hours, and the ratio of total wages and salaries to production worker wages. We also re-estimate the TFP regression by specifying labor input to include non-production workers, which yields qualitatively similar results. Values for the capital stock $(\mathrm{K})$ are generated by the recursive perpetual inventory formula. We use the earliest available book value of capital as the initial value of net stock of plant capital (this is either the value in 1972, or the first year a plant appears in the LRD sample). These values are written forward annually with nominal

\footnotetext{
${ }^{31}$ This measure of TFP is more flexible than the cash-flow measure of performance, as it does not impose the restriction of constant returns to scale and constant elasticity of scale. Also, since coefficients on capital, labor, and material inputs can vary by industry and year, this specification allows for different factor intensities in different industries. These production function estimates are pooled across the entire universe of manufacturing plants in the LRD, including plants belonging to both public and private firms, thus giving us an accurate measure of the relative performance of a plant within a particular 4-digit SIC industry in any given year. The TFP measure for each individual plant is the estimated residual of these regressions. Thus, it is the difference between the actual output produced by the plant compared to its "predicted output". This "predicted output" is what the plant should have produced, given the amount of inputs it used and the industry production technology in place. Hence a plant that produces more than the predicted amount of output in any given year has a greater than average productivity for that year. Thus, TFP can be understood as the relative productivity rank of a plant within its industry in any given year.
} 
capital expenditure (appropriately deflated at the industry level) and depreciated by the economic depreciation rate at the industry level obtained from the Bureau of Economic Analysis. Since values of all these variables are available separately for buildings and machinery, we perform this procedure separately for each category of assets. The resulting series are then added together to yield our capital stock measure. Finally, material input (M) is defined as expenses for the cost of materials and parts purchased, resales, contract work, and fuel and energy purchased, adjusted for the change in the value of material inventories. All the variables are deflated using annual price deflators for output, materials, and investment at the four-digit SIC level from the Bartelsman and Gray NBER Productivity Database. Deflators for capital stock are available from the Bureau of Economic Analysis. Plant level TFP measures are then aggregated to the firm level by a value weighted approach, where the weights on each plant is the ratio of its output (total value of shipments) to the total output of the firm. The firm level TFP is winsorized at the 1st and 99th percentile.

\subsection{Definitions of Variables for Tests of Hypotheses $\boldsymbol{H}_{5}$ to $\boldsymbol{H}_{9}$}

We test hypotheses $\mathbf{H}_{5}$ to $\mathbf{H}_{9}$ by using our overall IPO sample (not restricted to the manufacturing firms in the LRD). Our basic measure for a firm's post-IPO operating performance is its return on assets (ROA) for the first fiscal year after the IPO date (Compustat item DATA13/DATA6). ${ }^{32}$ To test the seventh and eighth hypotheses $\left(\mathbf{H}_{7}\right.$ and $\mathbf{H}_{8}$ ), we also construct two variables to measure firms' usage of cash raised in the IPO: (1) the increase in cash and cash equivalents in the IPO year scaled by total net assets at the first fiscal year-end after the IPO (DATA274/DATA6); and (2) cash and short-term investments at the first fiscal year-end after the IPO scaled by total net assets (DATA1/DATA6). To test the ninth hypothesis $\left(\mathbf{H}_{9}\right)$, we need a measure of industry concentration. Following previous literature, we calculate the Herfindahl-Hirschman Index (HHI) based on public firms' market share in total book assets within the FF-49 industries. ${ }^{33}$

We construct other control variables for hypotheses $\mathbf{H}_{5}$ to $\mathbf{H}_{9}$ following standard procedures in the literature. These include: (1) Firms' financial statement variables (from Compustat): logarithm of firm's market capital (DATA199*DATA25) at the first fiscal year end after the IPO; capital expenditure scaled by firm's net property, plant, and equipment (DATA128/DATA8); research \& development expenses scaled by total net assets (DATA46/DATA6); and firms' market share within the FF-49 industries based on all Compustat firms' net sales (DATA12). (2) IPO characteristics (from SDC and Jay Ritter's database): IPO's offer price; a dummy variable showing whether the

\footnotetext{
${ }^{32}$ We have also tried different measures including post-IPO operating cash flows over assets (DATA13-DATA128 divided by DATA6), return on equity (ROE: DATA172/DATA60), and the profit margin (DATA172/DATA12), which all yield similar results to the ones reported here. To gauge the impact of IPO timing on firms' long-term operating performance, we also repeated our study by using the two-year and three-year averages of post-IPO ROA, operating cash flow over assets, ROE, and profit margin, and obtain broadly similar results.

${ }^{33}$ The market share is calculated by using data for all public firms' net assets (DATA6) available in Compustat, thus may have not incorporated the impact of private firms. However, given the unavailablity of private firms' data outside the LRD, this is the best available. This limitation also applies to our measure of market share based on total net sales (DATA12) used as a control variable. For robustness, we also calculated HHI based on firms' market share in total net sales and book equity and obtain similar results.
} 
issuer is backed by venture capitalists (equals 1 if yes); the initial return of the IPO firm's stock price (difference between the first closing price and the offer price, divided by the offer price); logarithm of total IPO proceeds; percentage of secondary shares sold in the IPO; logarithm of firm's age at IPO date (the number of years between the firm's founding year (from Jay Ritter's database) and the IPO year); and the reputation of underwriters. ${ }^{34}$ (3) Institutional investors' holdings for a company's stock (from the Thomson Financial $13 f$ Institutional Holdings database): percentage of shares owned by all types of institutional investors right after the IPO but before the first fiscal year-end for the firm as a fraction of the total number of shares outstanding in the firm reported in CRSP. In case there are more than one disclosure for the holdings, we use the first one. To reduce the effect of outliers, all financial ratios in our study are winsorized at their $1 \%$ and $99 \%$ values.

\subsection{Summary Statistics}

Table 1 reports descriptive statistics of IPO waves and IPO characteristics in our overall sample (not restricted to manufacturing firms in the LRD). Panel A gives the distribution of IPOs and IPO waves across different decades, both for the whole SDC sample and for the sample with available Compustat information. The 1990's have the most number of IPOs (3378) and the highest proportion of "on-the-wave" IPOs among all decades (more than $75 \%$ of the IPOs done between 1990 and 1999 occurred during a hot market). Based on our classification of IPO waves or "hot periods" (with the number of IPOs greater than or equal to five), 4180 IPOs took place during industry-based waves while the remaining 2467 offerings occurred during a "cold" period. Except for the 1990's, the number of "offthe-wave" IPOs seems to exceed the number of "on-the-wave" IPOs for all decades, suggesting that the "hot-issue" market for IPOs mainly took place in the 90's when productivity shocks hit many industries.

Panel B of Table 1 presents the distribution of IPO waves across the FF-49 industries. As we see, both the "Electronic Equipment" and "Wholesale" industry have sixteen IPO waves over the sample period, but the waves for the former have a larger magnitude: on average an IPO wave in the "Electronic Equipment" industry has approximately 25 offerings while a wave in the "Wholesale" industry has approximately 15 . The industries ranked the third to the fifth are: "Computer Hardware", "Retail", and "Medical Equipment", with 15, 14, and 13 IPO waves, respectively.

Panel $\mathrm{C}$ describes the duration of IPO waves in our sample. The mean length of a wave is 268 days while the median length is 211 days.

Panel D of Table 1 lists the five largest IPO waves in our sample. The "Computer Software" industry has the two biggest waves with 334 and 278 IPOs, respectively, within each hot-issuing period; the "Business Services" industry has the two next largest waves with 185 and 104 offerings, respectively; and the "Electronic Equipment" industry

\footnotetext{
${ }^{34}$ This variable, obtained from Jay Ritter's database, has a range from 0 to 9.1 , with the higher values indicating better reputation. For simplicity, we only use the reputation for bookrunners of the offerings.
} 
has the fifth largest wave with 81 IPOs. Three out of five of these giant waves took place during the tech bubble period (from 1998 to 2000). The wave from Nov., 1998 to Nov., 2000 in the "Computer Software" industry is the most "condensed" hot-issuing period because on average 15 firms in this industry went public per month during this wave and the maximum number of offerings within one month was as high as 27 .

Panel E of Table 1 gives summary statistics of our measures for the industry IPO clusteredness (IPONUM, IPONUM / Same Industry Vol., and IPONUM / Same Window Vol.) as well as the order of going public in a wave (EARLINESS, ORDER / Median ORDER, and Log (ORDER) multiplied by 100). A maximum of 100 percent for IPONUM / Same Window Vol. denotes that the IPOs occurred in the 90-day window centering an offering are all in the same industry as the given offering. Panel F presents summary statistics of IPO characteristics in our sample, which are by and large consistent with that in the existing literature.

Table 2 presents the summary statistics of firm characteristics for LRD manufacturing firms that go public (have an IPO) between 1972 and 2000 and for firms remaining private throughout the same sample period. All reported statistics are firm-year observations and for the sample of IPO firms only the years prior to the firm's IPO are included. These basic comparisons show that firms going public between 1972 and 2000 are on average more productive, larger, and older than firms that remain private. The average sales growth for firms that have an IPO is $14.5 \%$, which is significantly greater than the sales growth of firms remaining private, which is around $4 \%$. Moreover, the TFP of firms going public is on average 0.046 , while that of private firms is -0.012 , both of which suggest that firms going public are on average more productive and efficient and perform better than their industry peers.

\section{Empirical Tests and Results}

In this section, we discuss the empirical methodology used to test our hypotheses and report the results from our empirical analyses.

\subsection{Relation Between Going Public, the Market Share of IPO Firms Themselves, and the Market Share of Their Competitors}

In this subsection, we carry out a multivariate analysis of the relationship between going public and the market share of IPO firms themselves $\left(\mathbf{H}_{1}\right)$ as well as the relationship between going public and the market share of its competitors $\left(\mathbf{H}_{2}\right) .{ }^{35}$

Table 3 presents OLS regressions of 1-year and 3-year market share growth on an IPO dummy and other firmlevel characteristics. The sample consists of all U.S. manufacturing firms that either went public (IPO) or remained private in the LRD between 1972 and 2000. The IPO sample is restricted to the IPO year and the years when a firm

\footnotetext{
${ }^{35}$ Univariate analyses of these two hypotheses, though unreported, yield similar results.
} 
was private (prior to going public). The first two models report results with respect to 1-year market share growth, and the latter two models report results with respect to 3-year market share growth. IPO is a dummy that equals one if the firm went public in the current year, and equals zero otherwise. As we can see, the coefficient before $I P O$ is positive and significant at the $1 \%$ level, showing that IPO firms enjoy a significant increase in market share growth relative to those firms remaining private. ${ }^{36}$

Table 4 presents OLS regressions of 1-year and 3-year market share growth on the fraction of IPO firms in the same FF-49 industry (IPO Fraction), lagged market share growth, firm size (as proxied by log of capital stock), and firm age. All specifications include year and firm fixed effects. For each panel, models (1) and (4) analyze the market share growth of private firms; whereas models (2) and (5) analyze the market share growth of public firms. Our results show that IPO Fraction has a significantly negative relationship with both the 1-year and 3-year market share growth of private as well as public competitors in the same industry. Moreover, this correlation is considerably larger for private competitors than for public competitors. The magnitude of the drop is even larger for market share growth measured over a 3-year horizon. These results are both statistically and economically significant. Model (3) and (6) analyze the market share growth of both private and public firms together. Private is a dummy that equals one if the firm is private in the year that IPO Fraction is measured, and equals zero otherwise. As we can see, the interaction of Private and IPO Fraction is significantly negative, suggesting that private firms will experience a larger reduction in their market share growth than public firms when more competitors in the same industry go public. Overall, the evidence provided in Table 4 is consistent with our second hypothesis $\left(\mathbf{H}_{2}\right)$ that IPOs in a given industry will be associated with a reduction in the market share of same-industry competitors, and this negative correlation is larger for competitors that are private.

There are two possible scenarios that can explain the above findings. First, going public causes an increase in the IPO firm's market share and a reduction in its competitors' market share (which is our model assumption). Second, the anticipation of increased market share induces a firm to go public. Without a valid instrument for the going public decision of a firm, it is difficult to distinguish between the above two scenarios. Thus, while the above descriptive results are broadly consistent with the main assumption of our model, we do not wish to claim that going public causes an increase in the market share of the IPO firm or a reduction in the market share of its competitors.

\footnotetext{
${ }^{36}$ As a robustness check, we also matched IPO firms with private and already public firms of the same size (amount of capital stock) and in the same FF-49 industry in the IPO year. We then compared the 1-year and 3-year market share growth for these matched firms. We found that IPO firms enjoy a significantly positive increase in market share after they go public while the market share of matched private firms or those that are already public drop during the same period, with the drop for private firms the largest. These results are available from the authors upon request.
} 


\subsection{Total Factor Productivity (TFP), Industry IPO Clusteredness, and the Order of Going Public in a Wave}

In this subsection, we carry out a multivariate analysis of the different total factor productivity (TFP) between firms that go public in an IPO wave and those that go public outside it $\left(\mathbf{H}_{3}\right)$, and between firms that go public earlier in an IPO wave and those that go public later in the wave $\left(\mathbf{H}_{4}\right)$, after controlling for lagged TFP, size, age, and industry and year fixed effects. ${ }^{37}$

Table 5 presents the results of multiple regressions of total factor productivity (TFP) on our three measures of industry IPO clusteredness (Panel A) and our three measures of the order of going public within an IPO wave (Panel B). Models (1) to (3) study the TFP of IPO firms only in the years before going public, while the rest of the models study the TFP of IPO firms in all years before and after going public. Panel A shows that average TFP for firms that go public in a hot period (with larger clusteredness measures) is in general smaller than those that go public in a cold period, and this relationship is statistically significant at $5 \%$ level for both IPONUM / Same Industry Vol. and IPONUM / Same Window Vol. The significantly negative coefficients of our IPO clusteredness measures are consistent with our third hypothesis $\left(\mathbf{H}_{3}\right)$ that firms going public outside a wave have higher pre-IPO productivity than firms going public within a wave. The coefficient of -0.004 for IPONUM in model 6 tells us that a firm going public within a hot period of 8 other same-industry IPOs (75\% quantile of IPONUM) will on average have TFP 0.028 less than a firm going public within a cold period of only 1 other same-industry IPO (25\% quantile of IPONUM). Given the mean of TFP in our sample is 0.046 , this represents a $61 \%$ difference in TFP, which is economically significant.

The results in Panel B with respect to the order of going public in an IPO wave are much stronger: "on-the-wave" firms that go public later in a hot period (with larger measures for the order of going public) in general have smaller TFP than those that go public earlier in the wave, and this relationship is significant at the $5 \%$ level (and in some cases at the 1\%) for all three measures of the order of going public. This lends strong support to our fourth hypothesis $\left(\mathbf{H}_{4}\right)$ that firms going public earlier within a wave have higher pre-IPO productivity than firms going public later in the wave. The coefficient of -0.027 for EARLINESS in model 6 tells us that a firm going public earlier in a hot period (among the first $25 \%$ of firms going public in this IPO wave) will on average have a TFP 0.081 more than a firm going public later in the wave (among the last $25 \%$ of firms going public in this hot period). Given the mean of TFP in our sample is 0.046 , this represents a $176 \%$ difference in overall TFP, which is economically significant.

In sum, the empirical results presented in this subsection support the hypotheses that firms going public outside an IPO wave (i.e. in a cold market) will have higher productivity than those going public within an IPO wave, and that firms going public earlier in an IPO wave will have higher productivity than those going public later in the wave.

\footnotetext{
${ }^{37} \mathrm{An}$ unreported univariate analysis of TFP, industry IPO clusteredness, and the order of going public in a wave yields similar conclusions.
} 


\subsubsection{Alternative Explanations and Robustness Tests of TFP Analysis}

In this subsection, we discuss an alternative explanation of our TFP results and conduct several robustness tests regarding the above TFP analysis.

Our findings that firms going public outside a wave have higher productivity and better post-IPO operating performance than those going public within a wave and that firms going public earlier in a wave have higher productivity and better post-IPO operating performance than those going public later in the wave may also be generated by a model along the lines of Pastor and Veronesi (2005), as we discuss below (see section 7.3 below for our findings on post-IPO operating performance). Consider a setting where firms with different productivities (and expected profitabilities) are born gradually over time and go public as soon as market conditions allow them to do so. If a

firm is strong, then its threshold market condition for going public is low. Such firms will go public soon after they are born, even if the market conditions are not very good and no IPO wave is generated. When market conditions improve, weaker firms will start to go public, creating an IPO wave. Hence, firms going public outside a wave tend to have higher TFP and better post-IPO operating performance because these are the firms that can overcome unfavorable market conditions to go public, while those firms going public within a wave tend to have lower TFP and worse post-IPO operating performance. Similarly, early in a wave, when market conditions are good but not great, the stronger firms will go public. Later in the wave, if market conditions improve and become excellent, many lower-quality firms will go public. Therefore, firms going public earlier in a wave will have higher TFP and better post-IPO profitability than firms going public later in the wave.

The above alternative explanation implies that if the market conditions are constant, then we would not observe better quality (in terms of either TFP or post-IPO operating performance) of off-the-wave and early-in-the-wave firms. In contrast, our model is purely based on product market competition and does not require market conditions to differ when firms go public on the wave versus off the wave, and when firms go public early in a wave versus later in the wave. Hence, to distinguish our model predictions from the variant of the Pastor and Veronesi (2005) market condition theory outlined above, we control for short-term and long-term stock market conditions when empirically comparing the TFP and operating performance of on-the-wave versus off-the-wave firms, and early-in-the-wave versus later-in-the-wave firms. If, even after controlling for differences in such stock market conditions, we find that firms going public off the wave have higher TFP and better profitability than those going public within an IPO wave, and those going public early in a wave have higher TFP and better profitability than those going public later in the wave, these residual effects can be attributed to the product market effects suggested by our theory.

We therefore re-run our regressions on the effect of IPO clusteredness and the order of going public on TFP after controlling for various market condition variables. We use IPONUM / Same Industry Vol. as our measure of 
IPO clusteredness and EARLINESS as our measure of the order of going public. ${ }^{38}$ We construct various proxies for market conditions mainly following Pastor and Veronesi (2005): see Table VI and VII of their paper for their market condition variables. The market condition variables are for the month during which a given firm went public (and also first differences, lags, and leads of such variables). IPO Month Market Return is the total monthly return on the value-weighted portfolio of all NYSE, AMEX, and NASDAQ stocks. IPO Month Market Volatility is the standard deviation of daily value weighted market returns. IPO Month Risk-free Rate is the yield on a 1-month T-bill in excess of expected inflation, where the latter is the fitted value from an $\operatorname{AR}(12)$ process applied to the monthly series of log changes in CPI from the Bureau of Labor Statistics. IPO Month MB Ratio is the sum of market values of equity across all ordinary common shares divided by the sum of the most recent book values of equity. IPO Month Ind Stock Return is the monthly return on a value-weighted portfolio of NYSE, AMEX, and NASDAQ stocks in the same FF-49 industry of the IPO firm. IPO Month Aggregate ROE is aggregate return on equity. IPO Month New Firm MB is the log difference between the median MB Ratio of new firms and the median MB Ratio across all firms. IPO Month New Firm Vol is the difference between the median return volatility of new firms and market volatility. See Pastor and Veronesi (2005), section III.B.1, for more details on the construction of these variables and the motivation for using them as proxies for market conditions.

Our results incorporating the above controls are presented in Table A1 (as part of Internet Appendix A available from the authors' websites). We find that some of the market condition variables are significant in some regression specifications: for example, IPO Month Market Volatility is negative and significant in our regression for IPO clusteredness (model (1)), indicating that firms going public during these periods of greater market uncertainty have lower TFP on average. However, the significantly negative coefficients of IPONUM / Same Industry Vol. and EARLINESS across all specifications show that, even after controlling for short and long-term stock market conditions, firms going public outside a wave tend to have higher pre-IPO TFP than those going public within a wave, and firms going public earlier in a wave tend to have higher pre-IPO TFP than those going public later in the wave. In summary, even after controlling for various market conditions, we still find residual empirical support for the predictions of our product market theory of IPO waves.

\footnotetext{
${ }^{38}$ Due to space constraints, we present these robustness tests on the effect of IPO clusteredness and the order of going public on TFP after controlling for various market condition variables using only one measure of IPO clusteredness and one measure of the order of going public in a wave in Table A1 (as part of the Internet Appendix A available from the authors' websites). The results of additional specifications using these two measures as well as our analysis based on specifications using all three measures of clusteredness and the order of going public are also available upon request. While the significance level varies across specifications, these additional results are broadly similar to those presented in Table A1.
} 


\subsection{Post-IPO Operating Performance, Industry IPO Clusteredness, and the Order of Going Public in a Wave}

In this subsection, we carry out a multivariate analysis of the difference in post-issuance operating performance between firms that go public in an IPO wave and those that go public outside it $\left(\mathbf{H}_{5}\right)$, and between firms that go public earlier in an IPO wave and those that go public later in the wave $\left(\mathbf{H}_{6}\right) \cdot{ }^{39}$

Table 6 summarizes the results of the multivariate analysis of post-issuance ROA on our measures of industry IPO clusteredness as well as on our measures of the order of an IPO within a wave. To control for unobservable macroeconomic shocks that affect all firms in a given year, we put a dummy for IPO year in all our model specifications. Similarly, we use an industry dummy throughout our regressions to control for unobservable industry-invariant characteristics that may affect the operating performance of all firms in a certain industry. ${ }^{40}$

Model (1) provides results with respect to the measure IPONUM. The significantly negative coefficient of IPONUM is consistent with our fifth hypothesis $\left(\mathbf{H}_{5}\right)$ that firms going public outside a wave have better post-IPO profitability than firms going public within a wave. The coefficient of -0.0016 for IPONUM tells us that even after controlling for industry and time effects as well as various firm and IPO characteristics, a firm that goes public within a hot period of 8 other same-industry IPOs ( $75 \%$ quantile of IPONUM) will on average have an ROA $1.1 \%$ less than a firm that goes public within a cold period of only 1 other same-industry IPO (25\% quantile of IPONUM). Given that the mean of ROA in our sample is $5 \%$, this represents a $20 \%$ difference in post-issuance ROA, which is economically significant. Model (2) and model (3) provide results with respect to the measure IPONUM / Same Industry Vol. and IPONUM / Same Window Vol., respectively. The coefficients of these two measures are also negative and statistically significant at the $1 \%$ level.

Models (4) to (6) summarize the results of multiple regressions of post-issuance ROA on measures of the order of going public within a hot period. Model (4) provides results with respect to the measure EARLINESS. The coefficient of this measure is negative and significant at $5 \%$ level, which is consistent with our sixth hypothesis $\left(\mathbf{H}_{6}\right)$ that firms going public earlier within a wave have better post-IPO profitability than firms going public later in the wave. The coefficient of -0.0076 for EARLINESS means that a firm that goes public earlier in a hot period (among the first $25 \%$ of firms going public in this IPO wave) will on average have an ROA $2.3 \%$ more than a firm that goes public later in the wave (among the last $25 \%$ of firms going public in this hot period). Given that the mean ROA in our sample is $5 \%$, this represents a $46 \%$ difference in post-issuance ROA, which is economically significant. Model (5) and model (6) yield qualitatively similar results to those in model (4). Taken together, these empirical results support the hypothesis that, on average, firms going public earlier in an IPO wave will yield a better post-IPO

\footnotetext{
${ }^{39}$ An unreported univariate analysis of post-issuance operating performance, industry IPO clusteredness, and the order of going public in a wave yields results similar to that from our multivariate analysis.

${ }^{40}$ In unreported results, we tried three other specifications for each of the three measures of clusteredness as well as of the three measures of the order of going public within a wave. Our results are robust to these alternative specifications.
} 
profitability than those going public later in the wave.

In all our regressions using post-IPO ROA as the dependent variable, the coefficient for firm size as proxied by the logarithm of market capital is significantly positive, which also holds true if we use total net assets as an alternative size measure. Firm age as proxied by the logarithm of the number of years between a firm's founding year and its IPO year also exerts a significantly positive impact on firms' post-IPO operating performance. These results, consistent with the findings of previous studies such as Mikkelson, Partch, and Shah (1997), suggest that smaller and younger firms may be still in their early years of operations and thus need to incur greater setup costs or charge lower product prices to attract customers (thus earning smaller profit margins). In line with these findings, firms' capital expenditure and R\&D intensity both significantly reduce the profitability of the same fiscal year because they represent a form of investment that would pay off only in the long run. Similarly, firms' market share calculated based on net sales is not statistically significant, which may be the result of two offsetting forces. On the one hand, higher market share may boost sales and thus increase total cash flows. On the other hand, the firm's expenditures to increase its market share may lead to high operating costs, lowering the profits for the current fiscal year (but may benefit long-term profits).

Everything else equal, IPOs with larger total proceeds exhibit lower post-issuance ROA, which is consistent with the finding that larger firms (in terms of post-IPO market capital) tend to have better ROA. This is because conditional on the level of post-IPO market cap, larger total proceeds implies smaller pre-IPO firm size, indicating a lower profitability after the IPO. ${ }^{41}$ We also find that the offer price of an IPO is positively related to the issuer's post-IPO operating performance, which is consistent with the information spillover argument of Alti (2005) that a higher offer price reveals better news about firm quality. The dummy for VC backing shows a moderately significant negative impact on post-IPO ROA, which may be a consequence of VC-backed firms being able to go pulic when they are younger. We also find a significantly negative relationship between initial returns (underpricing) and post-IPO operating performance, which is consistent with Ritter (1991) who finds that initial returns are negatively correlated with long-run stock return performance. Our results show that the percentage of secondary shares sold in an offering is positively related to its post-IPO ROA, which is consistent with the finding of Mikkelson, Partch, and Shah (1997) but contradicts that of Jain and Kini (1994). This positive relationship might be the outcome of both issuers' and investment banks' efforts to reduce the unfavorable information conveyed by offerings with secondary share sales (suggested by models such as Leland and Pyle 1977): in order to successfully complete such an offering, the IPO firm must have better future prospects and a higher level of expected post-issuance operating profits. Lastly, we find that

\footnotetext{
${ }^{41}$ In fact, the variable Log (IPO proceeds) is highly correlated with the size variable Log (market cap) (with Pearson correlation coefficient of 0.85), suggesting some problem of multicollinearity. However, in unreported work, we run regressions with either one of them and obtain both qualitatively and quantitatively similar coefficients of IPO timing variables (measures for clusteredness and the order of going public). If we exclude Log (market cap), then IPO proceeds will have a significantly positive effect on post-IPO ROA if not controlling for firm age and underwriter reputation but a significantly negative effect after we control for firm age and underwriter reputation. If we exclude $\log$ (proceeds), then Log (market cap) continues to have a significantly positive impact on post-IPO ROA in all specifications. To avoid omitted variable bias, we thus include both of them in our current model specifications.
} 
IPO firms with more shares held by institutional investors and those underwritten by more reputable investment banks have a higher post-IPO ROA, which is consistent with the common intuition that institutional investors and higher reputation underwriters are associated with higher quality firms going public.

\subsubsection{Robustness Tests of Post-IPO Operating Performance Analysis}

In this subsection, we conduct several robustness tests regarding the above post-IPO operating performance analysis.

As we discussed in section 7.2.1, our findings that firms going public outside a wave have better post-IPO profitability than those going public within a wave and that firms going public earlier in a wave have better post-IPO profitability than those going public later in the wave may also be generated by a market condition model along the lines of Pastor and Veronesi (2005). Hence, to distinguish our model predictions from the market condition model of Pastor and Veronesi (2005), we now control for short-term and long-term stock market conditions when empirically comparing the post-IPO operating performance of on-the-wave versus off-the-wave firms, and early-in-the-wave versus later-inthe-wave firms.

As in section 7.2.1, we introduce several market condition variables into our regressions of the effect of IPO clusteredness and the order of going public on post-IPO profitability mainly following Pastor and Veronesi (2005). Our results incorporating the above controls are presented in Table A2 (as part of Internet Appendix A available from the authors' websites). ${ }^{42}$ Consistent with the variant of Pastor and Vernesi (2005) market condition theory discussed in section 7.2.1, the coefficient of IPO Month Market return is significantly negative in models (1) and (6), suggesting that firms going public during excellent market conditions tend to be lower-quality firms, and therefore show worse post-IPO operating performance. However, the significantly negative coefficients of IPONUM / Same Industry Vol. and EARLINESS in all model specifications show that even after controlling for short and long-term stock market conditions, firms going public outside a wave tend to have better post-IPO operating performance than those going public within a wave, and firms going public earlier in a wave tend to have better post-IPO operating performance than those going public later in the wave. In summary, while we find significant support for the variant of the Pastor and Veronesi (2005) model discussed in section 7.2.1, we also find residual empirical support for the predictions of our product market theory of IPO waves. ${ }^{43}$

We have also conducted a long-term post-IPO operating performance analysis by using the three-year average

\footnotetext{
${ }^{42}$ Due to space constraints, we present these robustness tests on the effect of IPO clusteredness and the order of going public on post-IPO operating performance after controlling for various market condition variables using only one measure of IPO clusteredness and one measure of the order of going public in a wave. The results of additional specifications using these two measures as well as our analysis based on additional specifications using all three measures of clusteredness and the order of going public are available upon request. These additional results are very similar to those presented in Table A2.

${ }^{43} \mathrm{As}$ a further robustness check, we separated our sample into two subsamples based on IPO Month Stock Return: a "hot" one (when IPO Month Market Return is above the median) and a "cold" one (when IPO Month Market Return is below the median). We regressed Post-IPO ROA on the three measures of clusteredness and the three measures of the order of going public in each subsample and found all the coefficients of these measures to be significantly negative, consistent with our model predictions.
} 
ROA after a firm goes public. ${ }^{44}$ These results are presented in Table A3 (as part of Internet Appendix A available from the authors' websites). Consistent with our predictions, models (1) to (3) show that firms going public outside a wave have better long-term post-IPO profitability than firms going public within a wave, even after controlling for various firm and market conditions. Similarly, models (4) to (6) show that firms going public earlier in a wave have better long-term post-IPO profitability than firms going public later in the wave, after various controls.

\subsection{Cash Usage, Industry IPO Clusteredness, and the Order of Going Public in a Wave}

In this subsection, we carry out a multivariate analysis of the different cash usage intensities between firms going public in an IPO wave and those going public outside it $\left(\mathbf{H}_{7}\right)$, and between firms going public earlier in an IPO wave and those going public later in the wave $\left(\mathbf{H}_{8}\right)$.

Table 7 presents the results of multiple regressions of post-IPO cash balance and increases in cash holdings on measures of IPO timing (industry clusteredness and the order of going public within an IPO wave). Panel A provides results with respect to our first cash usage measure: the post-IPO increase in cash and cash equivalents scaled by total net assets. As we can see, the increase in cash balance for firms going public in a hot period (with larger clusteredness measures) is in general more than those going public in a cold period, and this positive relationship is statistically significant at the $10 \%$ level for IPONUM and at the $5 \%$ level for IPONUM / Same Industry Vol. The results with respect to the order of going public in an IPO wave are much stronger: firms going public later in an IPO wave (with larger measures for the order of going public) in general have greater increases in cash balance than those going public earlier in the wave, and the positive relationship is significant at the $1 \%$ level for all three measures for the order of going public. An examination of other control variables shows that younger firms with larger post-IPO market capital, smaller IPO size (in terms of total proceeds), lower underwriter reputation, and those backed by venture capital have larger increases in cash and cash equivalents.

Panel B provides results with respect to our second cash usage measure: cash and short-term investments after the IPO scaled by total net assets. As in Panel A, the post-IPO cash balance for firms going public in an IPO wave (with larger clusteredness measures) is in general larger than for those going public off the wave, and this positive relationship is statistically significant at the $1 \%$ level for IPONUM and IPONUM / Same Industry Vol. Moreover, firms going public later in an IPO wave (with larger measures for the order of going public) in general have a larger balance in cash and short-term investments than those going public later in the wave, but the positive relationship is significant at the $1 \%$ level only for Log $(O R D E R)$. However, although the coefficients for EARLINESS and ORDER / Median ORDER are not statistically significant, the t-values are not very small (both bigger than 1.3).

\footnotetext{
${ }^{44}$ The two-year average ROA results are qualitatively similar and are available from the authors upon request.
} 
In sum, the empirical results presented in this subsection broadly support our hypotheses $\left(\mathbf{H}_{7}\right.$ and $\left.\mathbf{H}_{8}\right)$ that after controlling for the total amount of proceeds raised, firms going public within an IPO wave will on average hold more cash on hand (or, use less cash raised through their offerings) than firms going public off the wave, and that firms going public earlier in an IPO wave will on average hold more cash on hand than firms going public later in the wave. $^{45}$

\subsection{Post-IPO Operating Performance, Industry Concentration, and IPO Timing}

In this subsection, we carry out a multivariate analysis of the influence that industry concentration exerts on the relationship between post-issuance operating performance and IPO timing variables (clusteredness as well as the order of going public). We test whether higher industry concentration intensifies or weakens the superior post-IPO profitability of firms that go public in a cold period or earlier in a wave, which is our ninth hypothesis $\left(\mathbf{H}_{9}\right)$.

Table 8 summarizes the results of multiple regressions of post-issuance ROA on measures of IPO timing (clusteredness or the order of going public), the Herfindahl-Hirschman Index (HHI), and the interaction of HHI and IPO timing measures. If industry concentration amplifies the difference in post-IPO operating performance for firms that go public on the wave versus those that go public off the wave and for firms going public earlier in a wave versus those going public later in the wave, then we expect the coefficients before the interaction of HHI and timing variables to be significantly negative. If, on the other hand, industry concentration weakens the relationship between post-IPO ROA and the timing of an IPO, then we expect the interaction variable to be significantly positive. If industry concentration cannot adequately proxy for how IPOs enhance firms' product market competitiveness or the two effects that concentration has on the performance-timing relationship cancel each other, then the coefficient before the interaction term should be insignificant.

Panel A provides results with respect to industry IPO clusteredness. The interaction of HHI and clusteredness measures is positive in all three models and statistically significant when we use the measure IPONUM / Same Window Vol. Even for the models (1) and (2) where the interaction term is not statistically significant at the $10 \%$ level, the t-statistics are still greater than 1, showing weak evidence that industry concentration weakens the relationship between post-IPO ROA and the timing of an IPO. The main effect of clusteredness measures on post-issuance operating performance remains significantly negative, consistent with our findings in Table 6 (testing $\mathbf{H}_{5}$ ). Nevertheless, the Herfindahl-Hirschman Index itself has a weak negative impact on firms' post-IPO ROA, contradicting the common intuition that less competition (or more concentration) renders more opportunities to manipulate price and earn higher monopoly rents.

Panel B presents results with respect to the order of going public within a given IPO wave. Similar to Panel

\footnotetext{
${ }^{45}$ By defining hot and cold periods according to total monthly IPO volume (for all industries), Alti (2006) also finds that hot-market issuers raise more equity than needed, adding more of the IPO proceeds to their cash and short-term investments than to other long-term assets. However, he does not examine the cash usage of firms going public earlier versus later within an IPO wave.
} 
A, the interaction of HHI and earliness measures is positive in all three models. Moreover, the positive effect is much more significant than in Panel A, with all three t-statistics exceeding 2.29. This finding strongly supports the conclusion that industry concentration weakens the relationship between post-IPO ROA and the timing of an IPO. The main effect of measures for the order of going public in a wave on post-issuance operating performance remains significantly negative, consistent with our findings in Table 6 (testing $\mathbf{H}_{6}$ ). In addition, the Herfindahl-Hirschman Index itself has a strong negative impact on firms' post-IPO ROA, consistent with our findings in Panel A as well as the sign of interaction variables in Panel B.

In sum, our results suggest that a public debut will add less to a firm's product market competitiveness in highly concentrated industries and may thus fail to induce it to go public purely out of competition concerns. Therefore, it seems to be the case that larger firms that already have significant market share in an industry as private firms do not have too much to gain by going public. This is because such firms may already have considerable credibility with potential employees, customers, and suppliers even when they are private. Consequently, a higher level of industry concentration weakens the difference in post-IPO performance for firms that go public on the wave versus those that go public off the wave, and firms going public earlier in a wave versus those going public later in the wave.

\section{Conclusion}

In this paper, we have developed a new rationale for IPO waves based on product market considerations. In our model, two firms, with differing productivity levels, compete in an industry with a significant probability of a positive productivity shock. Going public, though costly, not only allows a firm to raise external capital cheaply, but also enables it to grab market share from its private competitors. We solved for the decision of each firm to go public versus remain private, and the optimal timing of going public. In equilibrium, even firms with sufficient internal capital to fund their investment may go public, driven by the possibility of their product market competitors going public. IPO waves may arise in equilibrium even in industries which do not experience a productivity shock. Our model predicts that firms going public during an IPO wave will have lower productivity and post-IPO profitability but larger cash holdings than those going public off the wave; it makes similar predictions for firms going public later versus earlier in an IPO wave. We empirically tested and found support for these predictions.

\section{References}

Allen, Franklin, and Gerald R. Faulhaber, 1989, Signaling by Underpricing in the IPO Market, Journal of Financial Economics 23, 303-323.

Alti, Aydogan, 2005, IPO Market Timing, Review of Financial Studies 18, 1105-1138.

Alti, Aydogan, 2006, How Persistent is the Impact of Market Timing on Capital Structure, Journal of Finance 61, $1681-1710$. 
Benveniste, Lawrence M., Alexander P. Ljungqvist, William J. Wilhelm, and Xiaoyun Yu, 2003, Evidence of Information Spillovers in the Production of Investment Banking Services, Journal of Finance 58, 577-608.

Boot, Arnoud W.A., Radhakrishnan Gopalan, and Anjan V. Thakor, 2006, The Entrepreneur's Choice between Private and Public Ownership, Journal of Finance 61, 803-836.

Chemmanur, Thomas J., 1993, The Pricing of Initial Public Offerings: A Dynamic Model with Information Production, Journal of Finance 48, 285-304.

Chemmanur, Thomas J., and An Yan, 2009, Product Market Advertising and New Equity Issues, Journal of Financial Economics 92, 40-65.

Chemmanur, Thomas J., and Paolo Fulghieri, 1999, A Theory of the Going-public Decision, Review of Financial Studies 12, 249-279.

Chemmanur, Thomas J., Shan He, and Debarshi Nandy, 2010, The Going Public Decision and the Product Market, Review of Financial Studies 23, 1855-1908.

Chod, Jiri, and Evgeny Lyandres, 2010, Strategic IPOs and Product Market Competition, Journal of Financial Economics, forthcoming.

Grinblatt, Mark, and Chuan Y. Hwang, 1989, Signaling and the Pricing of New Issues, Journal of Finance 44, $393-420$.

Helwege, Jean, and Nellie Liang, 2004, Initial Public Offerings in Hot and Cold Markets, Journal of Financial and Quantitative Analysis 39, 541-560.

Hsu, Hung-Chia, Adam V. Reed, and Jörg Rocholl, 2010, The New Game in Town: Competitive Effects of IPOs, Journal of Finance 65, 495-528.

Jain, Bharat A., and Omesh Kini, 1994, The Post-Issue Operating Performance of IPO Firms, Journal of Finance 49, 1699-1726.

Khanna, Naveen, Thomas H. Noe, and Ramana Sonti, 2008, Good IPOs Draw in Bad: Inelastic Banking Capacity and Hot Markets, Review of Financial Studies 21, 1873-1906.

Killian, Linda R., Kathleen S. Smith, and Kathleen Smith, 2001, IPOs for Everyone: The 12 Secrets of Investing in IPOs, Indiana: Wiley.

Lanchester, Frederick W., 1916, Aircraft in Warfare: The Dawn of the Fourth Arm, London: Constable.

Leland, Hayne, and David Pyle, 1977, Information Asymmetries, Financial Structure, and Financial Intermediation, Journal of Finance 32, 371-387.

Lieberman, Marvin B., and David B. Montgomery, 1988, First-Mover Advantages, Strategic Management Journal 9, 41-58.

Lowry, Michelle, 2003, Why Does IPO Volume Fluctuate So Much? Journal of Financial Economics 67, 3-40.

Lowry, Michelle, and G.William Schwert, 2002, IPO Market Cycles: Bubbles or Sequential Learning?, Journal of Finance 57, 1171-1200.

Maksimovic, Vojislav, and Pegaret Pichler, 2001, Technological Innovation and Initial Public Offerings, Review of Financial Studies 14, 459-494.

Mikkelson, Wayne H., Megan M. Partch, and Kshitij Shah, 1997, Ownership and Operating Performance of Companies that Go Public, Journal of Financial Economics 44, 281-307.

Pagano, Marco, Fabio Panetta, and Luigi Zingales, 1998, Why Do Companies Go Public? An Empirical Analysis, Journal of Finance 53, 27-64.

Pastor, Lubos, and Pietro Veronesi, 2005, Rational IPO Waves, Journal of Finance 60, 1713-1757.

Pastor, Lubos, Lucian Taylor, and Pietro Veronesi, 2009, Entrepreneurial Learning, the IPO Decision, and the Post-IPO Drop in Firm Profitability, Review of Financial Studies 22, 3005-3046. 
Ritter, Jay R., 1984, The "Hot Issue" Market of 1980, Journal of Business 57, 215-240.

Ritter, Jay R., 1987, The Costs of Going Public, Journal of Financial Economics 19, 269-280.

Ritter, Jay R., 1991, The Long-Run Performance of Initial Public Offerings, Journal of Finance 46, 3-27.

Ritter, Jay R., and Ivo Welch, 2002, A Review of IPO Activity, Pricing, and Allocations, Journal of Finance 57, 1795-1828.

Robinson, William T., Gurumurthy Kalyanaram, and Glen L. Urban, 1994, First-Mover Advantages from Pioneering New Markets: A Survey of Empirical Evidence, Review of Industrial Organization 9, 1-23.

Schmalensee, Richard, 1978, Entry Deterrence in the Ready to Eat Breakfast Cereal Industry, Bell Journal of Economics 9, 305-327.

Slovin, Myron B., Marie E. Sushka, and Steven R. Ferraro, 1995, A Comparison of the Information Conveyed by Equity Carve-outs, Spin-offs, and Asset Sell-offs, Journal of Financial Economics, 37, 89-104.

Spence, Michael, 1981, The Learning Curve and Competition, Bell Journal of Economics 12, 49-70.

Spiegel, Matthew, and Heather Tookes, 2007, Dynamic Competition, Innovation and Strategic Financing, Working Paper, Yale University.

Stoughton, Neal M., Kit P. Wong, and Josef Zechner, 2001, IPOs and Product Quality, Journal of Business 74, 375-408.

Yung, Chris, Gönül Çolak, and Wei Wang, 2008, Cycles in the IPO Market, Journal of Financial Economics 89, 192-208.

Welch, Ivo, 1989, Seasoned Offerings, Imitation Costs, and the Underpricing of Initial Public Offerings, Journal of Finance 44, 421-449.

Wernerfelt, Birger, 1985, Brand Loyalty and User Skills, Journal of Economic Behavior and Organization 6, 381-385.

Wooldridge, Jeffrey, M., 2002, Econometric Analysis of Cross Section and Panel Data, MIT press, Cambridge. 
Panel D: The five largest IPO waves in the sample

\begin{tabular}{|c|c|c|c|c|c|c|c|c|c|}
\hline & Industry Name & $\begin{array}{l}\text { Number } \\
\text { of IPOs }\end{array}$ & $\begin{array}{l}\text { Beginning } \\
\text { Month of } \\
\text { Wave }\end{array}$ & $\begin{array}{l}\text { Ending } \\
\text { Month } \\
\text { Wave } \\
\end{array}$ & $\begin{array}{l}\text { Mean } \\
\text { IPOs of } \\
\text { month }\end{array}$ & $\begin{array}{l}\text { Median No. } \\
\text { of IPOs per } \\
\text { month }\end{array}$ & $\begin{array}{l}\text { Std of IPO } \\
\text { Volume } \\
\text { across month }\end{array}$ & $\begin{array}{l}\text { Minimum } \\
\text { No. of IPOs } \\
\text { per month }\end{array}$ & $\begin{array}{l}\text { Maximum } \\
\text { No. of IPOs } \\
\text { per month }\end{array}$ \\
\hline $1^{\text {st }}$ & Computer Software & 334 & Oct., 1994 & Aug., 1998 & 9.0 & 9 & 3.9 & $0 *$ & 18 \\
\hline $2^{\text {nd }}$ & Computer Software & 278 & Nov., 1998 & Nov., 2000 & 15.2 & 15 & 6.2 & 1 & 27 \\
\hline $3^{\text {rd }}$ & Business Services & 185 & Jun., 1995 & Aug., 1998 & 6.0 & 6 & 2.3 & $0 * *$ & 10 \\
\hline $4^{\text {th }}$ & Business Services & 104 & Feb., 1999 & Aug., 2000 & 7.2 & 6 & 3.2 & 1 & 13 \\
\hline $5^{\text {th }}$ & Electronic Equipment & 81 & Apr., 1999 & Nov., 2000 & 5.5 & 6 & 2.9 & 1 & 11 \\
\hline
\end{tabular}

* The only month that has zero IPOs in the wave is Nov., 1994.

** The only month that has zero IPOs in the wave is Jan., 1998

Panel E: Summary statistics for measures of Industry IPO clusteredness and the order of going public in a wave

\begin{tabular}{|c|c|c|c|c|c|c|c|}
\hline & Measure & No. of Obs. & Mean & Median & Std & Min & Max \\
\hline \multirow[t]{3}{*}{ Industry Clusteredness } & IPONUM & 6647 & 8.0 & 5.0 & 10.1 & 1.0 & 72.0 \\
\hline & IPONUM/Same Industry Vol. (\%) & 6647 & 2.3 & 1.8 & 2.0 & 0.1 & 40.0 \\
\hline & IPONUM/Same Window Vol. (\%) & 6647 & 8.2 & 5.5 & 8.2 & 0.5 & 100.0 \\
\hline \multirow[t]{8}{*}{ Order in a Wave } & ORDER / Median ORDER (\%) & 4180 & 99.9 & 100.0 & 55.1 & 1.2 & 199.4 \\
\hline & Log (ORDER) (multiplied by 100) & 4180 & 286.1 & 270.8 & 128.5 & 69.3 & 581.4 \\
\hline & \multirow[t]{6}{*}{ EARLINESS } & Category & Number & Percentage & & & \\
\hline & & 0 & 972 & 23.25 & & & \\
\hline & & 1 & 1174 & 28.09 & & & \\
\hline & & 2 & 1055 & 25.24 & & & \\
\hline & & 3 & 979 & 23.42 & & & \\
\hline & & Total & 4180 & 100 & & & \\
\hline
\end{tabular}

Panel F: Summary statistics for IPO characteristics

\begin{tabular}{|c|c|c|c|c|c|c|}
\hline Measure & No. of Obs. & Mean & Median & Std & Min & Max \\
\hline Offer Price (\$) & 6647 & 12.1 & 12.0 & 5.7 & 5.0 & 189.6 \\
\hline Initial Return (\%) & 4182 & 25.6 & 11.4 & 50.0 & -96.0 & 697.5 \\
\hline IPO proceeds (\$ million) & 6646 & 54.5 & 24.0 & 173.2 & 0.3 & 7322.4 \\
\hline Secondary Shares (\%) & 6646 & 14.5 & 0.0 & 22.8 & 0.0 & 100.0 \\
\hline Firm Age at IPO Date (Years) & 5455 & 13.6 & 7.0 & 18.5 & 0.0 & 165.0 \\
\hline Underwriter Reputation (0-9.1) & 5442 & 7.2 & 8.1 & 2.2 & 0.0 & 9.1 \\
\hline \multirow[t]{4}{*}{ Dummy for VC backing (Yes=1) } & Category & Number & Percentage & & & \\
\hline & 0 & 4008 & 60.3 & & & \\
\hline & 1 & 2639 & 39.7 & & & \\
\hline & Total & 6647 & 100 & & & \\
\hline
\end{tabular}




\section{Table 2: Summary Statistics of the LRD Sample}

This table presents summary statistics for firms that went public and firms that remained private in the LRD between 1972 and 2000. The going public firms are those firms in the manufacturing sector (SIC 2000-3999) that went public between 1972 and 2000 as recorded in SDC. The firms remaining private are all the firms in the LRD which did not have an IPO between 1972 and 2000, and which were not public prior to 1972. All statistics are firm-year observations, with the IPO sample being restricted to the years when the firms were private, prior to going public. Capital Stock is constructed via the perpetual inventory method and is the sum of building assets plus machinery assets. Sales is the total value of shipments in thousands of dollars. Age is the number of years since the birth of the first plant of the firm as recorded in the Census data. Capital intensity is the capital stock over total employment. TFP is the weighted average of plant level Total Factor Productivity at the four digit SIC level. To calculate TFP one regresses the value of output (total value of shipments adjusted for changes in inventories) on labor (production worker equivalent man hours), capital stock, and material inputs (intermediate inputs, fuels, and energy consumed). Sales growth is the average growth in sales in the past three years. Total wage is sum of total salaries and wages of the firm (in thousands of dollars). Average wage is total wage over total employment. Material Cost is the expenses for the cost of materials and parts purchased, resales, contract work, and fuel and energy purchased in thousands of dollars. Rental and Administrative Expenses is the rental payments or equivalent charges made during the year for the use of buildings, structures, and various office equipments in thousands of dollars. All the dollar values are in real terms. The last two columns report the $t$-stat and the z-stat for the test of difference in means and the distribution between the sample of firms going public and the sample of firms remaining private, respectively. ${ }^{* * *}, * *$, and $*$ indicate significance at the 1,5 , and 10 percent levels respectively.

\begin{tabular}{|c|c|c|c|c|c|c|c|c|}
\hline & \multicolumn{3}{|c|}{ Firms Going Public } & \multicolumn{3}{|c|}{ Firms Remaining Private } & \multicolumn{2}{|c|}{ Test of Differences } \\
\hline & Mean & Std. Dev. & Obs. & Mean & Std. Dev. & Obs. & $\begin{array}{c}\text { Mean } \\
\text { difference } \\
t \text {-test }\end{array}$ & $\begin{array}{l}\text { Wilcoxon } \\
\text { rank-sum } \\
\text { test }\end{array}$ \\
\hline Capital Stock & 63451.570 & 110107.700 & 6401 & 5443.286 & 25768.150 & 918445 & $170.00^{* * *}$ & $96.06 * * *$ \\
\hline Total Employment & 1295.147 & 1795.960 & 6401 & 150.792 & 448.210 & 918445 & $190.00 * * *$ & $100.72 * * *$ \\
\hline Total Sales & 168558.700 & 274834.900 & 6401 & 17021.850 & 65688.850 & 918445 & $170.00 * * *$ & $100.20 * * *$ \\
\hline Capital Intensity & 43.664 & 48.830 & 6401 & 24.229 & 36.369 & 882929 & $42.44 * * *$ & $52.13^{* * *}$ \\
\hline Age & 7.048 & 6.047 & 6401 & 5.178 & 5.652 & 918445 & $26.38 * * *$ & $31.49 * * *$ \\
\hline TFP & 0.046 & 0.246 & 6361 & -0.012 & 0.250 & 869203 & $18.63^{* * *}$ & $22.43^{* * *}$ \\
\hline Sales Growth & 0.145 & 0.338 & 5260 & 0.038 & 0.356 & 637287 & $21.76^{* * *}$ & $27.09 * * *$ \\
\hline Total Wage & 38131.420 & 55686.820 & 6401 & 3948.162 & 13190.770 & 918445 & $200.00 * * *$ & $103.23 * * *$ \\
\hline Average Wage & 29.447 & 10.246 & 6401 & 24.368 & 10.437 & 882929 & $38.77 * * *$ & $39.75^{* * *}$ \\
\hline Materials Cost & 95429.530 & 160667.400 & 6401 & 10559.200 & 42532.190 & 918445 & $150.00^{* * *}$ & $95.48^{* * *}$ \\
\hline Rental \& Admin. Exp. & 7857.582 & 11935.600 & 6401 & 775.621 & 2821.635 & 918445 & $190.00^{* * *}$ & $101.72 * * *$ \\
\hline
\end{tabular}




\section{Table 3: Relationship between Going Public and the IPO Firm's Own Market Share Growth}

This table presents OLS regressions of 1-year and 3-year market share growth on IPO dummy and other firm-level characteristics. The sample consists of all U.S. manufacturing firms that either went public (IPO) or remain private in the LRD between 1972 and 2000. The IPO sample is restricted to the IPO year and the years when a firm was private (prior to going public). The 1-year market share growth is the difference between the log market share in the next year and the current log market share (based on firm sales in the FF-49 industry). The 3-year market share growth is the difference between the log market share three years later and the current $\log$ market share. IPO is a dummy that equals one if the firm went public in the current year, and equals zero otherwise. Log (capital stock) is the natural logarithm of firm capital stock in thousands of dollars, where capital stock is constructed via the perpetual inventory method and is the sum of building assets plus machinery assets. TFP, measured one year prior to IPO, is the value weighted average of plant level Total Factor Productivity at the four digit SIC level, where one regresses the value of output (total value of shipments adjusted for changes in inventories) on labor (production worker equivalent man hours), capital stock, and material inputs (intermediate inputs, fuels, and energy consumed). Sales growth is the average growth in sales in the past three years. Market share is firms' market share within the FF-49 industries based on all LRD firms' sales. Capex Ratio is capital expenditure over capital stock. Venture Capital is a dummy that equals one if the firm is backed by venture capitalists. All models control for industry and year fixed effects. White standard errors, clustered at the firm level, adjusted for possible correlation within the cluster (Rogers standard errors) are reported. Heteroskedasticity-robust $t$-statistics are reported in parentheses. ${ }^{* * *}, * *$, and * indicate significance at the 1,5 , and 10 percent levels, respectively.

\begin{tabular}{|c|c|c|c|c|}
\hline \multirow[t]{2}{*}{ Dependent Variable } & \multicolumn{2}{|c|}{ 1-year Market Share Growth } & \multicolumn{2}{|c|}{ 3-year Market Share Growth } \\
\hline & (1) & $(2)$ & (3) & (4) \\
\hline \multirow[t]{2}{*}{$I P O$} & $0.113^{* * *}$ & $0.092 * * *$ & $0.219 * * *$ & $0.175^{* * *}$ \\
\hline & $(5.64)$ & $(4.71)$ & $(5.18)$ & $(4.21)$ \\
\hline \multirow[t]{2}{*}{ Lagged Dependent Variable } & $-0.087 * * *$ & $-0.095^{* * *}$ & $-0.155^{* * *}$ & $-0.182 * * *$ \\
\hline & $(37.06)$ & $(28.90)$ & (32.46) & (25.66) \\
\hline \multirow[t]{2}{*}{ Log (capital stock) } & $0.001^{* * *}$ & $0.009 * * *$ & $-0.016^{* * *}$ & $-0.008 * * *$ \\
\hline & (3.92) & $(16.46)$ & (12.53) & (2.69) \\
\hline \multirow[t]{2}{*}{ TFP } & & $-0.049 * * *$ & & $-0.047 * * *$ \\
\hline & & (29.05) & & $(7.56)$ \\
\hline \multirow[t]{2}{*}{ Market Share } & & $-7.022^{* * *}$ & & $-3.968 * * *$ \\
\hline & & (16.53) & & (3.14) \\
\hline \multirow[t]{2}{*}{ Sales Growth } & & $0.029 * * *$ & & $0.169 * * *$ \\
\hline & & $(7.55)$ & & $(7.72)$ \\
\hline \multirow[t]{2}{*}{ Capex Ratio } & & $0.063 * * *$ & & $0.266 * * *$ \\
\hline & & $(10.72)$ & & (12.17) \\
\hline \multirow[t]{2}{*}{ Venture Capital } & & $0.028 * * *$ & & $0.075^{* * *}$ \\
\hline & & (3.64) & & $(2.92)$ \\
\hline \multirow[t]{2}{*}{ Constant } & $-0.118 * * *$ & $-0.111^{* * *}$ & $-0.097 * *$ & $-0.153^{* * *}$ \\
\hline & $(10.23)$ & (8.79) & $(2.01)$ & $(2.88)$ \\
\hline Observations & 437578 & 363228 & 119734 & 112786 \\
\hline R-squared & 0.01 & 0.02 & 0.04 & 0.04 \\
\hline
\end{tabular}




\section{Table 4: Relationship between Other Firms’ IPOs and the Market Share Growth of Private and Public}

Competitors

This table presents OLS regressions of 1-year and 3-year market share growth on the fraction of IPO firms in the same FF-49 industry (IPO Fraction) and other firm-level characteristics. The sample consists of all U.S. manufacturing firms (both public and private) in the LRD between 1972 and 2000. The 1-year market share growth is the difference between the log market share in the next year and the current log market share (based on firm sales in the FF-49 industry). The 3-year market share growth is the difference between the log market share three years later and the current log market share. IPO Fraction is the total number of IPOs in the current year divided by the total number of firms (both public and private) in the same FF-49 industry in the same year. Log (capital stock) is the natural logarithm of firm capital stock in thousands of dollars in the current year, where capital stock is constructed via the perpetual inventory method and is the sum of building assets plus machinery assets. Log (age) is the number of years since the birth of the first plant of the firm as recorded in the Census data. TFP, measured one year prior to IPO, is the value weighted average of plant level Total Factor Productivity at the four digit SIC level, where one regresses the value of output (total value of shipments adjusted for changes in inventories) on labor (production worker equivalent man hours), capital stock, and material inputs (intermediate inputs, fuels, and energy consumed). Sales growth is the average growth in sales in the past three years. Market share is firms' market share within the FF-49 industries based on all LRD firms' sales. Capex Ratio is capital expenditure over capital stock. Venture Capital is a dummy that equals one if the firm is backed by venture capitalists. Model (1) and (4) analyze the market share growth of private firms; model (2) and (5) analyze the market share growth of public firms; and model (3) and (6) analyze the market share growth of both private and public firms. Private is a dummy that equals one if the firm is private in the current year, and equals zero otherwise. Panel A reports results with respect to 1-year market share growth, and Panel B reports results with respect to 3-year market share growth. All models control for firm and year fixed effects. Heteroskedasticity-robust $t$-statistics are reported in parentheses. ${ }^{* * *},{ }^{* *}$, and $*$ indicate significance at the 1,5 , and 10 percent levels, respectively.

Panel A: 1-year market share growth

\begin{tabular}{|c|c|c|c|c|c|c|}
\hline \multirow[t]{3}{*}{ Dependent Variable } & \multicolumn{3}{|c|}{ 1-year Market Share Growth } & \multicolumn{3}{|c|}{ 1-year Market Share Growth } \\
\hline & (1) & (2) & (3) & (4) & (5) & (6) \\
\hline & Private & Public & Both & Private & Public & Both \\
\hline \multirow[t]{2}{*}{ IPO Fraction } & $-8.148 * * *$ & $-4.316 * * *$ & $-4.702 * * *$ & $-7.790 * * *$ & $-3.306 * * *$ & $-3.768 * * *$ \\
\hline & $(11.70)$ & (3.96) & $(5.20)$ & $(11.28)$ & $(3.04)$ & (4.19) \\
\hline \multirow[t]{2}{*}{ Private*IPO Fraction } & & & $-3.054 * * *$ & & & $-3.586 * * *$ \\
\hline & & & $(2.79)$ & & & (3.29) \\
\hline \multirow[t]{2}{*}{ Private } & & & 0.000 & & & -0.010 \\
\hline & & & $(0.48)$ & & & $(0.83)$ \\
\hline \multirow[t]{2}{*}{ Lagged Dependent Variable } & $-0.261 * * *$ & $-0.169 * * *$ & $-0.245^{* * *}$ & $-0.251^{* * *}$ & $-0.155^{* * *}$ & $-0.235 * * *$ \\
\hline & $(152.97)$ & (34.59) & $(152.25)$ & $(120.61)$ & $(28.76)$ & $(121.68)$ \\
\hline \multirow[t]{2}{*}{ Log (capital stock) } & $-0.031 * * *$ & $-0.043 * * *$ & $-0.032 * * *$ & $-0.031 * * *$ & $-0.043 * * *$ & $-0.032 * * *$ \\
\hline & $(39.21)$ & $(20.52)$ & $(44.17)$ & (38.72) & $(20.24)$ & $(43.97)$ \\
\hline \multirow[t]{2}{*}{ Log (age) } & $-0.168 * * *$ & $-0.196 * * *$ & $-0.174 * * *$ & $-0.161^{* * *}$ & $-0.197 * * *$ & $-0.169 * * *$ \\
\hline & $(28.42)$ & $(10.11)$ & (31.98) & (27.39) & $(10.02)$ & $(31.00)$ \\
\hline \multirow[t]{2}{*}{ TFP } & & & & $-0.108^{* * *}$ & $-0.079 * * *$ & $-0.106 * * *$ \\
\hline & & & & $(42.02)$ & (9.75) & (43.37) \\
\hline \multirow[t]{2}{*}{ Market Share } & & & & $-6.574 * * *$ & $-1.908 * * *$ & $-2.342 * * *$ \\
\hline & & & & (19.88) & (10.88) & (17.19) \\
\hline \multirow[t]{2}{*}{ Sales Growth } & & & & $-0.108 * * *$ & $-0.105 * * *$ & $-0.107 * * *$ \\
\hline & & & & $(22.95)$ & (7.99) & $(24.53)$ \\
\hline \multirow[t]{2}{*}{ Capex Ratio } & & & & $0.013 *$ & $0.117^{* * *}$ & $0.025^{* * *}$ \\
\hline & & & & $(1.76)$ & $(4.34)$ & (3.45) \\
\hline \multirow[t]{2}{*}{ Venture Capital } & & & & $0.078 * * *$ & $0.059 * *$ & $0.065^{* * *}$ \\
\hline & & & & (3.34) & $(2.57)$ & $(4.42)$ \\
\hline
\end{tabular}




\begin{tabular}{lcccccc} 
Constant & $0.501^{* * *}$ & $0.640^{* * *}$ & $0.338^{* * *}$ & $0.332 * * *$ & $0.657^{* * *}$ & $0.357^{* * *}$ \\
& $(26.30)$ & $(20.92)$ & $(31.86)$ & $(38.28)$ & $(21.33)$ & $(33.67)$ \\
Observations & 439224 & 48463 & 487687 & 437140 & 48297 & 485437 \\
R-squared & 0.08 & 0.05 & 0.07 & 0.09 & 0.05 & 0.08 \\
\hline
\end{tabular}

Panel B: 3-year market share growth

\begin{tabular}{|c|c|c|c|c|c|c|}
\hline \multirow[t]{3}{*}{ Dependent Variable } & \multicolumn{3}{|c|}{ 3-year Market Share Growth } & \multicolumn{3}{|c|}{ 3-year Market Share Growth } \\
\hline & (1) & (2) & (3) & (4) & (5) & (6) \\
\hline & Private & Public & Both & Private & Public & Both \\
\hline \multirow[t]{2}{*}{ IPO Fraction } & $-10.789 * * *$ & $-5.091 * * *$ & $-5.060 * * *$ & $-10.115^{* * *}$ & $-4.349 * * *$ & $-4.659 * * *$ \\
\hline & $(7.08)$ & (3.08) & (3.39) & $(6.77)$ & $(2.71)$ & (3.18) \\
\hline \multirow[t]{2}{*}{ Private*IPO Fraction } & & & $-5.561^{* * *}$ & & & $-5.243^{* * *}$ \\
\hline & & & $(2.76)$ & & & $(2.66)$ \\
\hline \multirow[t]{2}{*}{ Private } & & & 0.000 & & & -0.010 \\
\hline & & & $(0.11)$ & & & $(1.04)$ \\
\hline \multirow[t]{2}{*}{ Lagged Dependent Variable } & $-0.331 * * *$ & $-0.301 * * *$ & $-0.317 * * *$ & $-0.283 * * *$ & $-0.236 * * *$ & $-0.273 * * *$ \\
\hline & $(104.91)$ & $(50.42)$ & $(113.95)$ & $(70.98)$ & (31.93) & $(77.92)$ \\
\hline \multirow[t]{2}{*}{ Log (capital stock) } & $-0.110 * * *$ & $-0.123 * * *$ & $-0.113^{* * *}$ & $-0.096 * * *$ & $-0.096 * * *$ & $-0.096 * * *$ \\
\hline & $(55.57)$ & $(31.50)$ & $(64.43)$ & $(47.44)$ & $(24.41)$ & $(54.09)$ \\
\hline \multirow[t]{2}{*}{ Log (age) } & $-0.388 * * *$ & $-0.447 * * *$ & $-0.402 * * *$ & $-0.332 * * *$ & $-0.258 * * *$ & $-0.321 * * *$ \\
\hline & $(15.91)$ & (8.39) & $(18.56)$ & $(13.83)$ & (4.96) & (15.07) \\
\hline \multirow[t]{2}{*}{ TFP } & & & & $-0.114 * * *$ & $-0.092 * * *$ & $-0.115^{* * *}$ \\
\hline & & & & (19.26) & (7.50) & (21.45) \\
\hline \multirow[t]{2}{*}{ Market Share } & & & & $-107.161^{* * *}$ & $-69.420 * * *$ & $-77.339 * * *$ \\
\hline & & & & (50.95) & (38.50) & (59.95) \\
\hline \multirow[t]{2}{*}{ Sales Growth } & & & & $0.035 * *$ & $0.136^{* * *}$ & $0.069 * * *$ \\
\hline & & & & $(2.41)$ & $(5.27)$ & $(5.45)$ \\
\hline \multirow[t]{2}{*}{ Capex Ratio } & & & & $0.096 * * *$ & 0.050 & $0.088 * * *$ \\
\hline & & & & $(4.74)$ & $(1.21)$ & $(4.76)$ \\
\hline \multirow[t]{2}{*}{ Venture Capital } & & & & $0.226 * * *$ & $0.060^{*}$ & $0.126 * * *$ \\
\hline & & & & $(5.50)$ & $(1.81)$ & (5.16) \\
\hline \multirow[t]{2}{*}{ Constant } & $1.899 * * *$ & $2.057 * * *$ & $2.042 * * *$ & $1.778 * * *$ & $1.898 * * *$ & $1.851^{* * *}$ \\
\hline & (24.39) & $(23.84)$ & (29.05) & (23.24) & $(22.50)$ & $(26.78)$ \\
\hline Observations & 120990 & 32790 & 153780 & 120512 & 32717 & 153229 \\
\hline R-squared & 0.14 & 0.13 & 0.14 & 0.16 & 0.17 & 0.16 \\
\hline
\end{tabular}




\section{Table 5: Total Factor Productivity (TFP), Industry IPO Clusteredness, and the Order of Going Public in a Wave}

This table presents OLS regressions of total factor productivity (TFP) on the three measures of industry IPO clusteredness and the three measures of the order of going public within an IPO wave. The sample consists of U.S. manufacturing firms in the LRD that went public between 1972 and 2000 . TFP is the value weighted average of plant level Total Factor Productivity at the four digit SIC level, where one regresses the value of output (total value of shipments adjusted for changes in inventories) on labor (production worker equivalent man hours), capital stock, and material inputs (intermediate inputs, fuels, and energy consumed). The three industry IPO clusteredness measures and the three measures for the order of going public within an IPO wave are defined as in Table 1. Log (capital stock) is the natural logarithm of firm capital stock in thousands of dollars, where capital stock is constructed via the perpetual inventory method and is the sum of building assets plus machinery assets. Log (age) is the number of years since the birth of the first plant of the firm as recorded in the Census data. Years from IPO year are a series of dummies to indicate the gap between the current year and the IPO year of the firm. Model (1) to (3) studies the TFP of IPO firms only in the years before going public, while the rest of the models study the TFP of IPO firms in all years before and after going public. Panel A presents the results for the three measures of industry IPO clusteredness and Panel B presents the results for the three measures of the order of going public within an IPO wave. Panel A analyzes all firms that went public during the sample period, while Panel B analyzes only firms that went public within IPO waves that include at least 5 same-industry IPOs. All models control for industry (FF-49 level) and IPO-year fixed effect. White standard errors, clustered at the firm level, adjusted for possible correlation within the cluster (Rogers standard errors) are reported. Heteroskedasticity-robust $t$-statistics are reported in parentheses. ***, **, and * indicate significance at the 1,5 , and 10 percent levels, respectively.

Panel A: TFP and IPO clusteredness

Dependent Variable: $\quad$ Total Factor Productivity (TFP)

\begin{tabular}{|c|c|c|c|c|c|c|c|c|c|c|c|c|}
\hline & \multicolumn{3}{|c|}{ Years Before Going Public } & \multicolumn{9}{|c|}{ Years Before and After Going Public } \\
\hline IPONUM & $\begin{array}{l}-0.010 \\
(1.60)\end{array}$ & & & $\begin{array}{c}-0.008^{* * *} \\
(2.78)\end{array}$ & $\begin{array}{c}-0.004^{* *} \\
(2.22)\end{array}$ & $\begin{array}{c}-0.004^{* *} \\
(2.55)\end{array}$ & & & & & & \\
\hline IPONUM/Same Window Vol. & & & $\begin{array}{c}-2.520 * * \\
(2.01)\end{array}$ & & & & & & & $\begin{array}{c}-2.367 * * \\
(2.44)\end{array}$ & $\begin{array}{c}-1.019 * * \\
(2.13)\end{array}$ & $\begin{array}{c}-0.855^{*} \\
(1.71)\end{array}$ \\
\hline Log (capital stock) & $\begin{array}{c}0.011^{* *} \\
(2.29)\end{array}$ & $\begin{array}{c}0.011^{* *} \\
(2.39)\end{array}$ & $\begin{array}{c}0.011^{* *} \\
(2.30)\end{array}$ & $\begin{array}{c}0.007 * * * \\
(2.78)\end{array}$ & $\begin{array}{c}0.003^{* *} \\
(2.32)\end{array}$ & $\begin{array}{c}0.003^{* *} \\
(2.37)\end{array}$ & $\begin{array}{c}0.007^{* * *} \\
(2.90)\end{array}$ & $\begin{array}{c}0.003^{* *} \\
(2.38)\end{array}$ & $\begin{array}{c}0.004^{* *} \\
(2.42)\end{array}$ & $\begin{array}{c}0.007 * * * \\
(2.87)\end{array}$ & $\begin{array}{c}0.003^{* *} \\
(2.38)\end{array}$ & $\begin{array}{c}0.004 * * \\
(2.50)\end{array}$ \\
\hline Log (age) & $\begin{array}{l}0.020 \\
(0.90)\end{array}$ & $\begin{array}{l}0.020 \\
(0.85)\end{array}$ & $\begin{array}{l}0.020 \\
(0.81)\end{array}$ & $\begin{array}{l}0.010 \\
(0.64)\end{array}$ & $\begin{array}{l}0.000 \\
(0.38)\end{array}$ & $\begin{array}{l}0.010 \\
(1.32)\end{array}$ & $\begin{array}{l}0.010 \\
(0.61)\end{array}$ & $\begin{array}{l}0.000 \\
(0.34)\end{array}$ & $\begin{array}{l}0.010 \\
(1.33)\end{array}$ & $\begin{array}{l}0.010 \\
(0.92)\end{array}$ & $\begin{array}{l}0.010 \\
(0.59)\end{array}$ & $\begin{array}{l}0.010 \\
(1.35)\end{array}$ \\
\hline Constant & $\begin{array}{r}-0.020 \\
(0.34) \\
\end{array}$ & $\begin{array}{l}0.020 \\
(0.30) \\
\end{array}$ & $\begin{array}{l}0.030 \\
(0.51) \\
\end{array}$ & $\begin{array}{l}0.050 \\
(1.31) \\
\end{array}$ & $\begin{array}{l}0.000 \\
(0.09) \\
\end{array}$ & $\begin{array}{c}0.209 * * * \\
(3.91)\end{array}$ & $\begin{array}{l}0.086^{*} \\
(1.78) \\
\end{array}$ & $\begin{array}{l}0.020 \\
(0.52) \\
\end{array}$ & $\begin{array}{c}0.188 * * * \\
(3.85) \\
\end{array}$ & $\begin{array}{c}0.088^{*} \\
(1.89) \\
\end{array}$ & $\begin{array}{l}0.020 \\
(0.46) \\
\end{array}$ & $\begin{array}{c}0.149 * * * \\
(3.39) \\
\end{array}$ \\
\hline Years from IPO Year & No & No & No & No & No & Yes & No & No & Yes & No & No & Yes \\
\hline
\end{tabular}


Panel B: TFP and the order of going public in an IPO wave Dependent Variable:

Total Factor Productivity (TFP)

\begin{tabular}{|c|c|c|c|c|c|c|c|c|c|c|c|c|}
\hline & \multicolumn{3}{|c|}{ Years Before Going Public } & \multicolumn{9}{|c|}{ Years Before and After Going Public } \\
\hline & (1) & (2) & (3) & (4) & (5) & (6) & (7) & (8) & (9) & $(10)$ & (11) & (12) \\
\hline EARLINESS & $\begin{array}{c}-0.063 * * * \\
(2.81)\end{array}$ & & & $\begin{array}{c}-0.049 * * * \\
(2.67)\end{array}$ & $\begin{array}{c}-0.027^{* *} \\
(2.44)\end{array}$ & $\begin{array}{c}-0.027^{* *} \\
(2.34)\end{array}$ & & & & & & \\
\hline $\log (O R D E R)$ & & & $\begin{array}{c}-0.088^{* *} \\
(2.52)\end{array}$ & & & & & & & $\begin{array}{c}-0.072 * * * \\
(2.72)\end{array}$ & $\begin{array}{c}-0.038 * * \\
(2.31)\end{array}$ & $\begin{array}{c}-0.038^{* *} \\
(2.23)\end{array}$ \\
\hline Log (capital stock) & $\begin{array}{l}0.000 \\
(0.30)\end{array}$ & $\begin{array}{l}0.000 \\
(0.27)\end{array}$ & $\begin{array}{l}0.000 \\
(0.11)\end{array}$ & $\begin{array}{l}0.010 \\
(1.23)\end{array}$ & $\begin{array}{l}0.000 \\
(1.15)\end{array}$ & $\begin{array}{c}0.000 \\
(1.15)\end{array}$ & $\begin{array}{l}0.010 \\
(1.19)\end{array}$ & $\begin{array}{l}0.000 \\
(1.12)\end{array}$ & $\begin{array}{c}0.000 \\
(1.11)\end{array}$ & $\begin{array}{l}0.010 \\
(1.06)\end{array}$ & $\begin{array}{c}0.000 \\
(1.02)\end{array}$ & $\begin{array}{c}0.000 \\
(1.00)\end{array}$ \\
\hline Log (age) & $\begin{array}{c}0.059 * * \\
(2.26)\end{array}$ & $\begin{array}{c}0.058^{* *} \\
(2.23)\end{array}$ & $\begin{array}{c}0.058^{* *} \\
(2.20)\end{array}$ & $\begin{array}{c}0.041^{*} \\
(1.89)\end{array}$ & $\begin{array}{l}0.010 \\
(0.74)\end{array}$ & $\begin{array}{l}0.020 \\
(1.09)\end{array}$ & $\begin{array}{l}0.041^{*} \\
(1.88)\end{array}$ & $\begin{array}{l}0.010 \\
(0.73)\end{array}$ & $\begin{array}{l}0.020 \\
(1.09)\end{array}$ & $\begin{array}{c}0.039 * \\
(1.78)\end{array}$ & $\begin{array}{l}0.010 \\
(0.67)\end{array}$ & $\begin{array}{l}0.020 \\
(1.03)\end{array}$ \\
\hline Constant & $\begin{array}{l}0.220 \\
(1.12)\end{array}$ & $\begin{array}{l}0.260 \\
(1.30)\end{array}$ & $\begin{array}{l}0.330 \\
(1.62)\end{array}$ & $\begin{array}{c}0.349 * * * \\
(3.72) \\
\end{array}$ & $\begin{array}{l}0.090 \\
(1.51)\end{array}$ & $\begin{array}{l}-0.030 \\
(0.08)\end{array}$ & $\begin{array}{c}0.380^{* * *} \\
(4.05)\end{array}$ & $\begin{array}{l}0.103^{*} \\
(1.78)\end{array}$ & $\begin{array}{c}0.211^{* *} \\
(2.43)\end{array}$ & $\begin{array}{c}0.488^{* * *} \\
(4.57) \\
\end{array}$ & $\begin{array}{c}0.161^{* *} \\
(2.33) \\
\end{array}$ & $\begin{array}{l}0.090 \\
(0.30)\end{array}$ \\
\hline Years from IPO Year & No & No & No & No & No & Yes & No & No & Yes & No & No & Yes \\
\hline
\end{tabular}




\section{Table 6: Post-IPO Operating Performance, Industry Clusteredness of IPOs, and the Order of Going Public in an IPO Wave}

This table presents OLS regressions of post-IPO operating performance on three measures of industry IPO clusteredness ("hotness" of the IPO market) and the three measures for the order of going public within an IPO wave. The post-IPO operating performance measure is defined as the return on assets (ROA) for the first fiscal year after the IPO date (COMPUSTAT DATA13/DATA6). The three industry IPO clusteredness measures and the three measures for the order of going public within an IPO wave are defined as in Table 1. The other independent variables include: logarithm of firm's market capital (DATA199*DATA25) at the first fiscal year end after the IPO; IPO's offer price; a dummy variable showing whether the issuer is backed by venture capitalists (equals 1 if yes); the initial return of the IPO firm's stock (difference between the first closing price and the offer price, divided by the offer price); logarithm of total IPO proceeds; percentage of secondary shares sold in the IPO; firms' market share within the FF-49 industries based on all Compustat firms' net sales (DATA12); percentage of shares owned by institutional investors right after the IPO; logarithm of firm's age at IPO date (number of years between the firm's founding year and the IPO year); capital expenditure scaled by firm's net property, plant, and equipment (DATA128/DATA8); research \& development expenses scaled by total net assets (DATA46/DATA6); and the reputation for underwriters. IPO Month Market Return is the total monthly return on the value-weighted portfolio of all NYSE, AMEX, and NASDAQ stocks for the month during which the firm went public. IPO Month Market Volatility is computed as the standard deviation of daily value weighted market returns for the month during which the firm went public. IPO Month MB Ratio is the sum of market values of equity across all ordinary common shares divided by the sum of the most recent book values of equity for the month during which the firm went public. The first four columns in each panel analyze all firms that went public during the sample period, while the latter four columns analyze only firms that went public within IPO waves that include at least 5 same-industry IPOs. All models control for industry (FF-49 level) and IPO-year fixed effect. White standard errors, clustered at the industry level, adjusted for possible correlation within the cluster (Rogers standard errors) are reported. Heteroskedasticity-robust $t$-statistics are reported in parentheses. ${ }^{* * *}, * *$, and $*$ indicate significance at the 1,5 , and 10 percent levels, respectively.

\begin{tabular}{|c|c|c|c|c|c|c|}
\hline \multirow[t]{2}{*}{ Dependent Variable: } & \multicolumn{6}{|c|}{ ROA } \\
\hline & (1) & (2) & (3) & (4) & (5) & (6) \\
\hline IPONUM & $\begin{array}{c}-0.0016^{* * *} \\
(-4.16)\end{array}$ & & & & & \\
\hline IPONUM/Same Industry Vol. & & $\begin{array}{c}-0.6741^{* * *} \\
(-3.09)\end{array}$ & & & & \\
\hline IPONUM/Same Window Vol. & & & $\begin{array}{c}-0.2340 * * * \\
(-4.72)\end{array}$ & & & \\
\hline EARLINESS & & & & $\begin{array}{c}-0.0076^{* *} \\
(-2.40)\end{array}$ & & \\
\hline ORDER / Median ORDER & & & & & $\begin{array}{c}-0.0160 * * \\
(-2.71)\end{array}$ & \\
\hline $\log (O R D E R)$ & & & & & & $\begin{array}{c}-0.0086^{* * *} \\
(-3.00)\end{array}$ \\
\hline Log (market cap) & $\begin{array}{c}0.0579 * * * \\
\quad(8.61)\end{array}$ & $\begin{array}{c}0.0573^{* * *} \\
\quad(8.58)\end{array}$ & $\begin{array}{c}0.0579 * * * \\
(8.64)\end{array}$ & $\begin{array}{c}0.0543^{* * *} \\
\quad(8.20)\end{array}$ & $\begin{array}{c}0.0544^{* * *} \\
\quad(8.21)\end{array}$ & $\begin{array}{c}0.0542 * * * \\
(8.07)\end{array}$ \\
\hline Offer Price & $\begin{array}{c}0.0033^{* *} \\
(2.59)\end{array}$ & $\begin{array}{c}0.0033^{* *} \\
(2.56)\end{array}$ & $\begin{array}{c}0.0034^{* *} \\
(2.56)\end{array}$ & $\begin{array}{c}0.0035^{* *} \\
(2.13)\end{array}$ & $\begin{array}{c}0.0035^{* *} \\
(2.12)\end{array}$ & $\begin{array}{c}0.0036^{* *} \\
(2.25)\end{array}$ \\
\hline Dummy for VC backing & $\begin{array}{c}-0.0254 * * \\
(-2.41)\end{array}$ & $\begin{array}{c}-0.0270^{* *} \\
(-2.56)\end{array}$ & $\begin{array}{c}-0.0256^{* *} \\
(-2.48)\end{array}$ & $\begin{array}{c}-0.0373 * * * \\
(-3.51)\end{array}$ & $\begin{array}{c}-0.0374 * * * \\
(-3.52)\end{array}$ & $\begin{array}{c}-0.0370^{* * *} \\
(-3.46)\end{array}$ \\
\hline Initial Return (percent) & $\begin{array}{c}-0.0004^{* * *} \\
(-4.89)\end{array}$ & $\begin{array}{c}-0.0004 * * * \\
(-5.05)\end{array}$ & $\begin{array}{c}-0.0004 * * * \\
(-4.80)\end{array}$ & $\begin{array}{c}-0.0003^{* * *} \\
(-3.42)\end{array}$ & $\begin{array}{c}-0.0003^{* * *} \\
(-3.45)\end{array}$ & $\begin{array}{c}-0.0003^{* * *} \\
(-3.32)\end{array}$ \\
\hline Log (IPO proceeds) & $-0.0747 * * *$ & $-0.0732 * * *$ & $-0.0749 * * *$ & $-0.0815^{* * *}$ & $-0.0817 * * *$ & $-0.0818 * * *$ \\
\hline
\end{tabular}


Percent of Secondary Shares

Market Share

Percent of Institutional Holding

Log (firm age at IPO date)

CapEx/PPE

R\&D/Assets

Underwriter Reputation

IPO Month Market Return

IPO Month Market Volatility

IPO Month MB Ratio

Constant

Observations

R-squared

\begin{tabular}{|c|c|c|c|c|c|}
\hline$(-7.72)$ & $(-7.68)$ & $(-7.71)$ & $(-6.90)$ & $(-6.93)$ & $(-6.90)$ \\
\hline $0.2032 * * *$ & $0.2031 * * *$ & $0.2025 * * *$ & $0.2367 * * *$ & $0.2365 * * *$ & $0.2382 * * *$ \\
\hline (7.14) & $(7.00)$ & $(7.04)$ & (7.19) & (7.22) & (7.32) \\
\hline-0.2182 & -0.2513 & -0.2185 & 0.2956 & 0.2926 & 0.2398 \\
\hline$(-1.00)$ & $(-1.08)$ & $(-1.00)$ & $(0.51)$ & $(0.50)$ & $(0.41)$ \\
\hline $0.1165 * * *$ & $0.1196 * * *$ & $0.1176 * * *$ & $0.1392 * * *$ & $0.1391 * * *$ & $0.1396 * * *$ \\
\hline (5.83) & (5.91) & $(6.00)$ & (4.37) & (4.36) & $(4.42)$ \\
\hline $0.0317^{* * *}$ & $0.0312 * * *$ & $0.0315 * * *$ & $0.0316 * * *$ & $0.0315 * * *$ & $0.0318 * * *$ \\
\hline$(5.58)$ & (5.64) & $(5.62)$ & (5.33) & (5.30) & (5.34) \\
\hline$-0.0618 * * *$ & $-0.0638 * * *$ & $-0.0614 * * *$ & $-0.0827^{* * *}$ & $-0.0829 * * *$ & $-0.0812^{* * *}$ \\
\hline$(-4.76)$ & $(-4.96)$ & $(-4.71)$ & $(-5.76)$ & $(-5.78)$ & $(-5.52)$ \\
\hline$-1.0463 * * *$ & $-1.0528 * * *$ & $-1.0394 * * *$ & $-1.0647 * * *$ & $-1.0644 * * *$ & $-1.0539 * * *$ \\
\hline$(-8.84)$ & $(-8.98)$ & $(-8.88)$ & $(-8.82)$ & $(-8.76)$ & $(-8.71)$ \\
\hline $0.0095 * * *$ & $0.0092 * * *$ & $0.0094 * * *$ & $0.0111^{* * *}$ & $0.0111^{* * *}$ & $0.0111^{* * *}$ \\
\hline (4.93) & (4.81) & (5.01) & (4.85) & (4.84) & (4.90) \\
\hline
\end{tabular}

\begin{tabular}{cccccc}
$-0.0795^{* *}$ & $-0.0595^{*}$ & $-0.0768^{* *}$ & $-0.1616^{* *}$ & $-0.1550^{* *}$ & $-0.1592^{* *}$ \\
$(-2.15)$ & $(-1.72)$ & $(-2.11)$ & $(-2.69)$ & $(-2.61)$ & $(-2.61)$ \\
3259 & 3259 & 3259 & 2321 & 2321 & 2321 \\
0.556 & 0.555 & 0.557 & 0.581 & 0.581 & 0.581 \\
\hline
\end{tabular}


Table 7: Post-IPO Cash Balance, Industry Clusteredness of IPOs, and the Order of Going Public in an IPO Wave

This table presents OLS regressions of post-IPO cash balance on the three measures of industry IPO clusteredness and the three measures of the order of going public within an IPO wave. The post-IPO cash balance is measured in two ways: Panel A uses the increase in cash and cash equivalents scaled by total net assets (DATA274/DATA6) as the dependent variable; and Panel B uses cash and short-term investments scaled by total net assets (DATA1/DATA6). The three industry IPO clusteredness measures and the three measures for the order of going public within an IPO wave are defined as in Table 1. The other independent variables include: logarithm of firm's market capital (DATA199*DATA25) at the first fiscal year end after the IPO; IPO's offer price; a dummy variable showing whether the issuer is backed by venture capitalists (equals 1 if yes); the initial return of the IPO firm's stock (difference between the first closing price and the offer price, divided by the offer price); logarithm of total IPO proceeds; percentage of secondary shares sold in the IPO; firms' market share within the FF-49 industries based on all Compustat firms' net sales (DATA12); percentage of shares owned by institutional investors right after the IPO; logarithm of firm's age at IPO date (number of years between the firm's founding year and the IPO year); and the reputation for underwriters. The first three columns in each panel analyze all firms that went public during the sample period, while the latter three columns analyze only firms that went public within IPO waves that include at least 5 same-industry IPOs. All models control for industry (FF-49 level) and IPO-year fixed effect. White standard errors, clustered at the industry level, adjusted for possible correlation within the cluster (Rogers standard errors) are reported. Heteroskedasticity-robust $t$-statistics are reported in parentheses. ***, **, and * indicate significance at the 1 , 5 , and 10 percent levels, respectively.

Panel A: The increase in cash and cash equivalents after the IPO scaled by total net assets

Dependent Variable:

Increase in cash and cash equivalents after the IPO scaled by assets

\begin{tabular}{|c|c|c|c|c|c|c|}
\hline & & & & & & \\
\hline & $(1)$ & (2) & (3) & $(4)$ & (5) & (6) \\
\hline$\overline{I P O N U M}$ & $\begin{array}{c}0.0013^{*} \\
(1.83)\end{array}$ & & & & & \\
\hline IPONUM/Same Industry Vol. & & $\begin{array}{c}0.4190^{* *} \\
(2.12)\end{array}$ & & & & \\
\hline IPONUM/Same Window Vol. & & & $\begin{array}{c}0.0319 \\
(0.40)\end{array}$ & & & \\
\hline EARLINESS & & & & $\begin{array}{c}0.0201 * * * \\
(3.42)\end{array}$ & & \\
\hline ORDER / Median ORDER & & & & & $\begin{array}{c}0.0387 * * * \\
(3.53)\end{array}$ & \\
\hline $\log (O R D E R)$ & & & & & & $\begin{array}{c}0.0182 * * * \\
(4.09)\end{array}$ \\
\hline Log (market cap) & $\begin{array}{l}0.0212 * * * \\
\quad(5.56)\end{array}$ & $\begin{array}{l}0.0216 * * * \\
(5.52)\end{array}$ & $\begin{array}{c}0.0214 * * * \\
(5.41)\end{array}$ & $\begin{array}{c}0.0214 * * * \\
(4.88)\end{array}$ & $\begin{array}{c}0.0211 * * * \\
(4.82)\end{array}$ & $\begin{array}{l}0.0214 * * * \\
(5.02)\end{array}$ \\
\hline Offer Price & $\begin{array}{c}0.0020^{* *} \\
(2.15)\end{array}$ & $\begin{array}{c}0.0020^{* *} \\
(2.17)\end{array}$ & $\begin{array}{c}0.0021^{* *} \\
(2.20)\end{array}$ & $\begin{array}{c}0.0022 \\
(1.52)\end{array}$ & $\begin{array}{c}0.0021 \\
(1.52)\end{array}$ & $\begin{array}{c}0.0018 \\
(1.31)\end{array}$ \\
\hline Dummy for VC backing & $\begin{array}{c}0.0323 * * * \\
(3.65)\end{array}$ & $\begin{array}{c}0.0339 * * * \\
(3.94)\end{array}$ & $\begin{array}{c}0.0335 * * * \\
(3.81)\end{array}$ & $\begin{array}{c}0.0339 * * * \\
(3.21)\end{array}$ & $\begin{array}{c}0.0341 * * * \\
(3.23)\end{array}$ & $\begin{array}{c}0.0322^{* * *} \\
(3.10)\end{array}$ \\
\hline Initial Return (percent) & $\begin{array}{c}0.0003^{*} \\
(1.73)\end{array}$ & $\begin{array}{c}0.0003 * \\
(1.71)\end{array}$ & $\begin{array}{c}0.0003^{*} \\
(1.75)\end{array}$ & $\begin{array}{c}0.0002 \\
(1.19)\end{array}$ & $\begin{array}{c}0.0002 \\
(1.21)\end{array}$ & $\begin{array}{c}0.0002 \\
(1.15)\end{array}$ \\
\hline Log (IPO proceeds) & $-0.0426 * * *$ & $-0.0436 * * *$ & $-0.0429 * * *$ & $-0.0423 * * *$ & $-0.0420 * * *$ & $-0.0412 * * *$ \\
\hline
\end{tabular}




\begin{tabular}{|c|c|c|c|c|c|c|}
\hline & $(-6.09)$ & $(-6.39)$ & $(-6.15)$ & $(-4.38)$ & $(-4.36)$ & $(-4.40)$ \\
\hline \multirow[t]{2}{*}{ Percent of Secondary Shares } & 0.0054 & 0.0060 & 0.0054 & -0.0085 & -0.0082 & -0.0133 \\
\hline & $(0.32)$ & $(0.36)$ & $(0.33)$ & $(-0.37)$ & $(-0.35)$ & $(-0.60)$ \\
\hline \multirow[t]{2}{*}{ Market Share } & -0.5441 & -0.5264 & -0.5640 & $-1.7897 * * *$ & $-1.7628 * * *$ & $-1.6637 * * *$ \\
\hline & $(-1.09)$ & $(-1.05)$ & $(-1.11)$ & $(-3.91)$ & $(-3.92)$ & $(-3.77)$ \\
\hline \multirow[t]{2}{*}{ Percent of Institutional Holding } & 0.0083 & 0.0055 & 0.0058 & 0.0116 & 0.0116 & 0.0110 \\
\hline & $(0.45)$ & $(0.29)$ & $(0.32)$ & $(0.54)$ & $(0.54)$ & $(0.53)$ \\
\hline \multirow[t]{2}{*}{ Log (firm age at IPO date) } & $-0.0273 * * *$ & $-0.0271 * * *$ & $-0.0272 * * *$ & $-0.0173 * * *$ & $-0.0173 * * *$ & $-0.0178 * * *$ \\
\hline & $(-6.54)$ & $(-6.49)$ & $(-6.48)$ & $(-3.88)$ & $(-3.86)$ & $(-3.94)$ \\
\hline \multirow[t]{2}{*}{ Underwriter Reputation } & $-0.0134 * * *$ & $-0.0132 * * *$ & $-0.0132 * * *$ & $-0.0104^{* * *}$ & $-0.0104^{* * *}$ & $-0.0105 * * *$ \\
\hline & $(-5.30)$ & $(-5.26)$ & $(-5.29)$ & $(-3.58)$ & $(-3.61)$ & $(-3.52)$ \\
\hline \multirow[t]{2}{*}{ Constant } & $0.3419 * * *$ & $0.3316 * * *$ & $0.3464 * * *$ & $0.1936^{* * *}$ & $0.1832 * * *$ & $0.1970 * * *$ \\
\hline & (8.83) & (8.50) & (8.79) & (5.34) & (5.01) & (5.05) \\
\hline Observations & 3315 & 3315 & 3315 & 2362 & 2362 & 2362 \\
\hline R-squared & 0.208 & 0.207 & 0.206 & 0.194 & 0.194 & 0.194 \\
\hline
\end{tabular}

Panel B: The cash and short-term investments after the IPO scaled by total net assets

Dependent Variable: $\quad$ Cash and short-term investments after the IPO scaled by assets

\begin{tabular}{|c|c|c|c|c|c|c|}
\hline \multirow[t]{2}{*}{ Dependent varıable: } & \multicolumn{6}{|c|}{ Casn and snort-term investments atter the IPU scaled by assets } \\
\hline & $(1)$ & $(2)$ & $(3)$ & $(4)$ & $(5)$ & (6) \\
\hline$\overline{I P O N U M}$ & $\begin{array}{c}0.0021 * * * \\
(2.93)\end{array}$ & & & & & \\
\hline IPONUM/Same Industry Vol. & & $\begin{array}{c}0.8378 * * * \\
(2.74)\end{array}$ & & & & \\
\hline IPONUM/Same Window Vol. & & & $\begin{array}{c}0.1948 * * \\
(2.07)\end{array}$ & & & \\
\hline EARLINESS & & & & $\begin{array}{c}0.0104 \\
(1.37)\end{array}$ & & \\
\hline ORDER / Median ORDER & & & & & $\begin{array}{c}0.0218 \\
(1.60)\end{array}$ & \\
\hline $\log (O R D E R)$ & & & & & & $\begin{array}{c}0.0220 * * * \\
(3.38)\end{array}$ \\
\hline Log (market cap) & $\begin{array}{c}0.0168 * * * \\
(2.82)\end{array}$ & $\begin{array}{c}0.0175^{* * *} \\
(2.92)\end{array}$ & $\begin{array}{c}0.0170 * * * \\
(2.84)\end{array}$ & $\begin{array}{c}0.0114 * \\
(1.75)\end{array}$ & $\begin{array}{c}0.0113^{*} \\
(1.74)\end{array}$ & $\begin{array}{c}0.0121^{*} \\
(1.83)\end{array}$ \\
\hline Offer Price & $\begin{array}{c}0.0043^{* *} \\
(2.44)\end{array}$ & $\begin{array}{c}0.0043^{* *} \\
(2.42)\end{array}$ & $\begin{array}{c}0.0043^{* *} \\
(2.47)\end{array}$ & $\begin{array}{c}0.0044^{* *} \\
(2.03)\end{array}$ & $\begin{array}{c}0.0044^{* *} \\
(2.04)\end{array}$ & $\begin{array}{c}0.0042^{* *} \\
(2.04)\end{array}$ \\
\hline Dummy for VC backing & $\begin{array}{c}0.0998 * * * \\
(8.27)\end{array}$ & $\begin{array}{c}0.1024 * * * \\
(8.65)\end{array}$ & $\begin{array}{c}0.1007^{* * *} \\
(8.29)\end{array}$ & $\begin{array}{c}0.1000 * * * \\
(8.19)\end{array}$ & $\begin{array}{c}0.1001^{* * *} \\
(8.20)\end{array}$ & $\begin{array}{c}0.0982 * * * \\
(7.96)\end{array}$ \\
\hline Initial Return (percent) & $\begin{array}{c}0.0004^{* * *} \\
(3.20)\end{array}$ & $\begin{array}{c}0.0004^{* * *} \\
(3.09)\end{array}$ & $\begin{array}{c}0.0004^{* * *} \\
(3.11)\end{array}$ & $\begin{array}{c}0.0003^{* *} \\
(2.29)\end{array}$ & $\begin{array}{c}0.0003^{* *} \\
(2.32)\end{array}$ & $\begin{array}{c}0.0003^{* *} \\
(2.22)\end{array}$ \\
\hline
\end{tabular}




\begin{tabular}{|c|c|c|c|c|c|c|}
\hline Log (IPO proceeds) & $\begin{array}{c}-0.0637 * * * \\
(-6.08)\end{array}$ & $\begin{array}{c}-0.0656 * * * \\
(-6.67)\end{array}$ & $\begin{array}{c}-0.0636 * * * \\
(-6.11)\end{array}$ & $\begin{array}{c}-0.0604^{* * *} \\
(-3.96)\end{array}$ & $\begin{array}{c}-0.0603^{* * *} \\
(-3.97)\end{array}$ & $\begin{array}{c}-0.0594 * * * \\
(-3.91)\end{array}$ \\
\hline \multirow[t]{2}{*}{ Percent of Secondary Shares } & 0.0005 & 0.0017 & 0.0010 & -0.0084 & -0.0081 & -0.0125 \\
\hline & $(0.019)$ & $(0.063)$ & $(0.037)$ & $(-0.23)$ & $(-0.23)$ & $(-0.36)$ \\
\hline \multirow[t]{2}{*}{ Market Share } & -0.6013 & -0.5579 & -0.6163 & $-2.1010 * * *$ & $-2.0927 * * *$ & $-2.0575 * * *$ \\
\hline & $(-0.95)$ & $(-0.88)$ & $(-0.97)$ & $(-3.04)$ & $(-3.03)$ & $(-3.00)$ \\
\hline \multirow[t]{2}{*}{ Percent of Institutional Holding } & $-0.0734 * * *$ & $-0.0780 * * *$ & $-0.0758 * * *$ & $-0.0726 * *$ & $-0.0724 * *$ & $-0.0718^{* *}$ \\
\hline & $(-2.90)$ & $(-3.08)$ & $(-3.00)$ & $(-2.19)$ & $(-2.19)$ & $(-2.16)$ \\
\hline \multirow[t]{2}{*}{ Log (firm age at IPO date) } & $-0.0453 * * *$ & $-0.0450 * * *$ & $-0.0451 * * *$ & $-0.0407 * * *$ & $-0.0406 * * *$ & $-0.0407 * * *$ \\
\hline & $(-6.64)$ & $(-6.65)$ & $(-6.61)$ & $(-5.91)$ & $(-5.87)$ & $(-5.86)$ \\
\hline \multirow[t]{2}{*}{ Underwriter Reputation } & -0.0021 & -0.0018 & -0.0020 & 0.0030 & 0.0030 & 0.0025 \\
\hline & $(-0.56)$ & $(-0.49)$ & $(-0.52)$ & $(0.78)$ & (0.78) & $(0.64)$ \\
\hline \multirow[t]{2}{*}{ Constant } & $0.4603 * * *$ & $0.4377 * * *$ & $0.4613 * * *$ & $0.4564 * * *$ & $0.4478 * * *$ & $0.4173^{* * *}$ \\
\hline & $(8.72)$ & $(8.26)$ & (8.68) & (8.23) & (7.94) & (7.73) \\
\hline Observations & 3315 & 3315 & 3315 & 2362 & 2362 & 2362 \\
\hline R-squared & 0.481 & 0.479 & 0.479 & 0.475 & 0.475 & 0.479 \\
\hline
\end{tabular}


Table 8: Industry Concentration, Post-IPO Operating Performance, Industry Clusteredness of IPOs, and the Order of Going Public in an IPO Wave

This table presents OLS regressions of post-IPO operating performance on industry concentration, the three measures of industry IPO clusteredness, the three measures of the order of going public within an IPO wave, and the interaction between concentration and IPO clusteredness and order measures. The post-IPO operating performance measure is defined as the return on assets (ROA) for the first fiscal year after the IPO date (COMPUSTAT DATA13/DATA6). Industry concentration is the Herfindahl-Hirschman Index (HHI) calculated based on all Compustat firms' post-IPO total net assets within a certain FF-49 industry. The three industry IPO clusteredness measures and the three measures for the order of going public within an IPO wave are defined as in Table 1. The other independent variables include: logarithm of firm's market capital (DATA199*DATA25) at the first fiscal year end after the IPO; IPO's offer price; a dummy variable showing whether the issuer is backed by venture capitalists (equals 1 if yes); the initial return of the IPO firm's stock (difference between the first closing price and the offer price, divided by the offer price); logarithm of total IPO proceeds; percentage of secondary shares sold in the IPO; firms' market share within the FF-49 industries based on all Compustat firms' net sales (DATA12); percentage of shares owned by institutional investors right after the IPO; logarithm of firm's age at IPO date (number of years between the firm's founding year and the IPO year); capital expenditure scaled by firm's net property, plant, and equipment (DATA128/DATA8); research \& development expenses scaled by total net assets (DATA46/DATA6); and the reputation for underwriters. Panel A analyzes all firms that went public during the sample period, while Panel B analyzes only firms that went public within IPO waves that include at least 5 same-industry IPOs. All models control for industry (FF-49 level) and IPO-year fixed effect. White standard errors, clustered at the industry level, adjusted for possible correlation within the cluster (Rogers standard errors) are reported. Heteroskedasticity-robust $t$-statistics are reported in parentheses. ${ }^{* * *},{ }^{* *}$, and $*$ indicate significance at the 1,5 , and 10 percent levels, respectively.

Panel A: Industry concentration and IPO clusteredness

\begin{tabular}{|c|c|c|c|}
\hline \multirow{2}{*}{ Dependent Variable: } & \multicolumn{3}{|c|}{ ROA } \\
\hline & $(1)$ & (2) & (3) \\
\hline IPONUM & $\begin{array}{c}-0.0020 * * * \\
(-3.33)\end{array}$ & & \\
\hline Herfindahl Index * IPONUM & $\begin{array}{c}0.0064 \\
(1.37)\end{array}$ & & \\
\hline IPONUM/Same Industry Vol. (IPONUM_1) & & $\begin{array}{c}-0.8502 * * \\
(-2.58)\end{array}$ & \\
\hline Herfindahl Index * IPONUM_1 & & $\begin{array}{c}1.5138 \\
(1.07)\end{array}$ & \\
\hline IPONUM/Same Window Vol. (IPONUM_2) & & & $\begin{array}{c}-0.3086^{* * *} \\
(-4.49)\end{array}$ \\
\hline Herfindahl Index * IPONUM_2 & & & $\begin{array}{c}1.1343^{* * *} \\
(3.02)\end{array}$ \\
\hline Herfindahl Index & $\begin{array}{c}-0.0730^{*} \\
(-1.84)\end{array}$ & $\begin{array}{c}-0.0657 \\
(-0.92)\end{array}$ & $\begin{array}{c}-0.0966^{* *} \\
(-2.34)\end{array}$ \\
\hline Log (market cap) & $\begin{array}{c}0.0580^{* * *} \\
(8.60)\end{array}$ & $\begin{array}{c}0.0572^{* * *} \\
\quad(8.56)\end{array}$ & $\begin{array}{c}0.0581 * * * \\
\quad(8.61)\end{array}$ \\
\hline Offer Price & $\begin{array}{c}0.0033^{* *} \\
(2.60)\end{array}$ & $\begin{array}{c}0.0033^{* *} \\
(2.57)\end{array}$ & $\begin{array}{c}0.0034^{* *} \\
(2.58)\end{array}$ \\
\hline Dummy for VC backing & $\begin{array}{c}-0.0253^{* *} \\
(-2.44)\end{array}$ & $\begin{array}{c}-0.0270^{* *} \\
(-2.56)\end{array}$ & $\begin{array}{c}-0.0258 * * \\
(-2.50)\end{array}$ \\
\hline Initial Return (percent) & $\begin{array}{c}-0.0004^{* * *} \\
(-5.21)\end{array}$ & $\begin{array}{c}-0.0004 * * * \\
(-5.01)\end{array}$ & $\begin{array}{c}-0.0004^{* * * *} \\
(-5.12)\end{array}$ \\
\hline Log (IPO proceeds) & $\begin{array}{c}-0.0748 * * * \\
(-7.76)\end{array}$ & $\begin{array}{c}-0.0733^{* * *} \\
(-7.64)\end{array}$ & $\begin{array}{c}-0.0752^{* * * *} \\
(-7.73)\end{array}$ \\
\hline Percent of Secondary Shares & $\begin{array}{c}0.2019 * * * \\
(7.13)\end{array}$ & $\begin{array}{c}0.2028 * * * \\
(7.10)\end{array}$ & $\begin{array}{c}0.2012^{* * *} \\
(7.04)\end{array}$ \\
\hline Market Share & $\begin{array}{c}-0.2280 \\
(-1.06)\end{array}$ & $\begin{array}{c}-0.2478 \\
(-1.09)\end{array}$ & $\begin{array}{c}-0.2374 \\
(-1.10)\end{array}$ \\
\hline Percent of Institutional Holding & $\begin{array}{c}0.1162^{* * *} \\
\quad(5.95)\end{array}$ & $\begin{array}{c}0.1194^{* * *} \\
\quad(6.02)\end{array}$ & $\begin{array}{c}0.1171^{* * *} \\
\quad(6.13)\end{array}$ \\
\hline Log (firm age at IPO date) & $0.0317^{* * *}$ & $0.0312^{* * *}$ & $0.0315^{* * *}$ \\
\hline
\end{tabular}




\begin{tabular}{lccc} 
& $(5.56)$ & $(5.63)$ & $(5.61)$ \\
\hline CapEx/PPE & $-0.0623^{* * *}$ & $-0.0639^{* * *}$ & $-0.0618^{* * *}$ \\
R\&D/Assets & $(-4.81)$ & $(-4.94)$ & $(-4.75)$ \\
& $-1.0484^{* * *}$ & $-1.0527^{* * *}$ & $-1.0413^{* * *}$ \\
Underwriter Reputation & $(-8.94)$ & $(-9.03)$ & $(-9.01)$ \\
& $0.0095^{* * *}$ & $0.0092^{* * *}$ & $0.0095^{* * *}$ \\
Constant & $(4.96)$ & $(4.82)$ & $(5.11)$ \\
& $-0.0627^{*}$ & -0.0476 & -0.0557 \\
Observations & $(-1.78)$ & $(-1.59)$ & $(-1.64)$ \\
R-squared & 3259 & 3259 & 3259 \\
\end{tabular}

Panel B: Industry concentration and the order of going public in an IPO wave

\begin{tabular}{|c|c|c|c|}
\hline \multirow[t]{2}{*}{ Dependent Variable: } & \multicolumn{3}{|c|}{ ROA } \\
\hline & $(1)$ & $(2)$ & (3) \\
\hline EARLINESS & $\begin{array}{c}-0.0152 * * * \\
(-3.62)\end{array}$ & & \\
\hline Herfindahl Index * EARLINESS & $\begin{array}{c}0.0750^{* * *} \\
(3.40)\end{array}$ & & \\
\hline ORDER / Median ORDER (ORDER_N) & & $\begin{array}{c}-0.0271^{* * *} \\
(-3.46)\end{array}$ & \\
\hline Herfindahl Index * ORDER_N & & $\begin{array}{c}0.1092^{* *} \\
(2.57)\end{array}$ & \\
\hline Log (ORDER) & & & $\begin{array}{c}-0.0143^{* * *} \\
(-2.91)\end{array}$ \\
\hline Herfindahl Index * Log (ORDER) & & & $\begin{array}{c}0.0633^{* *} \\
(2.29)\end{array}$ \\
\hline Herfindahl Index & $\begin{array}{c}-0.1827 * * * \\
(-2.96)\end{array}$ & $\begin{array}{c}-0.1809 * * \\
(-2.50)\end{array}$ & $\begin{array}{c}-0.2266^{* * *} \\
(-4.05)\end{array}$ \\
\hline Log (market cap) & $\begin{array}{l}0.0541^{* * *} \\
\quad(8.13)\end{array}$ & $\begin{array}{l}0.0543^{* * *} \\
\quad(8.17)\end{array}$ & $\begin{array}{c}0.0542^{* * *} \\
\quad(7.96)\end{array}$ \\
\hline Offer Price & $\begin{array}{c}0.0034^{* *} \\
(2.08)\end{array}$ & $\begin{array}{c}0.0034^{* *} \\
(2.07)\end{array}$ & $\begin{array}{c}0.0037^{* *} \\
(2.32)\end{array}$ \\
\hline Dummy for VC backing & $\begin{array}{c}-0.0373^{* * *} \\
(-3.54)\end{array}$ & $\begin{array}{c}-0.0374 * * * \\
(-3.54)\end{array}$ & $\begin{array}{c}-0.0370 * * * \\
(-3.48)\end{array}$ \\
\hline Initial Return (percent) & $\begin{array}{c}-0.0003^{* * *} \\
(-3.39)\end{array}$ & $\begin{array}{c}-0.0003^{* * *} \\
(-3.40)\end{array}$ & $\begin{array}{c}-0.0003^{* * *} \\
(-3.50)\end{array}$ \\
\hline Log (IPO proceeds) & $\begin{array}{c}-0.0808^{* * * *} \\
(-6.90)\end{array}$ & $\begin{array}{c}-0.0810^{* * *} \\
(-6.94)\end{array}$ & $\begin{array}{c}-0.0818^{* * * *} \\
(-6.96)\end{array}$ \\
\hline Percent of Secondary Shares & $\begin{array}{c}0.2380^{* * *} \\
(7.21)\end{array}$ & $\begin{array}{c}0.2376^{* * * *} \\
\quad(7.24)\end{array}$ & $\begin{array}{c}0.2384 * * * \\
(7.34)\end{array}$ \\
\hline Market Share & $\begin{array}{c}0.2341 \\
(0.41)\end{array}$ & $\begin{array}{c}0.2381 \\
(0.42)\end{array}$ & $\begin{array}{c}0.1824 \\
(0.32)\end{array}$ \\
\hline Percent of Institutional Holding & $\begin{array}{c}0.1370^{* * *} \\
\quad(4.26)\end{array}$ & $\begin{array}{c}0.1371^{* * *} \\
\quad(4.26)\end{array}$ & $\begin{array}{c}0.1383^{* * *} \\
(4.38)\end{array}$ \\
\hline Log (firm age at IPO date) & $\begin{array}{c}0.0317 * * * \\
\quad(5.33)\end{array}$ & $\begin{array}{c}0.0316^{* * *} \\
(5.28)\end{array}$ & $\begin{array}{c}0.0319 * * * \\
(5.33)\end{array}$ \\
\hline CapEx/PPE & $\begin{array}{c}-0.0825 * * * \\
(-5.78)\end{array}$ & $\begin{array}{c}-0.0830 * * * \\
(-5.81)\end{array}$ & $\begin{array}{c}-0.0818^{* * * *} \\
(-5.60)\end{array}$ \\
\hline R\&D/Assets & $\begin{array}{c}-1.0615^{* * * *} \\
(-8.96)\end{array}$ & $\begin{array}{c}-1.0619 * * * \\
(-8.85)\end{array}$ & $\begin{array}{c}-1.0519 * * * \\
(-8.79)\end{array}$ \\
\hline Underwriter Reputation & $\begin{array}{c}0.0110^{* * * *} \\
(4.90)\end{array}$ & $\begin{array}{c}0.0110^{* * *} \\
(4.85)\end{array}$ & $\begin{array}{c}0.0112 * * * \\
\quad(4.97)\end{array}$ \\
\hline Constant & $\begin{array}{c}-0.1461^{* *} \\
(-2.46)\end{array}$ & $\begin{array}{c}-0.1400^{* *} \\
(-2.40)\end{array}$ & $\begin{array}{c}-0.1438 * * \\
(-2.31)\end{array}$ \\
\hline Observations & 2321 & 2321 & 2321 \\
\hline R-squared & 0.582 & 0.582 & 0.582 \\
\hline
\end{tabular}


Table A1: Robustness Tests on the Relationship between Pre-IPO Total Factor Productivity (TFP), Industry IPO Clusteredness, and the Order of Going Public in a Wave

This table presents OLS regressions of total factor productivity (TFP) on one measure of industry IPO clusteredness (IPONUM/Same Industry Vol.) and one measure of the order of going public within an IPO wave (EARLINESS), after controlling for various market condition variables. The sample consists of U.S. manufacturing firms in the LRD that went public between 1972 and 2000. TFP is the value weighted average of plant level Total Factor Productivity at the four digit SIC level, where one regresses the value of output (total value of shipments adjusted for changes in inventories) on labor (production worker equivalent man hours), capital stock, and material inputs (intermediate inputs, fuels, and energy consumed). IPONUM/Same Industry Vol. and EARLINESS are defined as in Table 1. Log (capital stock) is the natural logarithm of firm capital stock in thousands of dollars, where capital stock is constructed via the perpetual inventory method and is the sum of building assets plus machinery assets. Log (age) is the number of years since the birth of the first plant of the firm as recorded in the Census data. The market condition variables are for the month during which the firm went public. The notation " $\Delta$ " denotes changes (first differences), and "-n" ("+n") denotes monthly lags (leads). IPO Month Market Return is the total monthly return on the value-weighted portfolio of all NYSE, AMEX, and NASDAQ stocks. IPO Month Market Volatility is the standard deviation of daily value weighted market returns. IPO Month Risk-free Rate is the real risk-free rate. IPO Month MB Ratio is the sum of market values of equity across all ordinary common shares divided by the sum of the most recent book values of equity. IPO Month Aggregate ROE is aggregate return on equity. IPO Month New Firm MB is the log difference between the median MB Ratio of new firms and the median MB Ratio across all firms. IPO Month New Firm Vol is the difference between the median return volatility of new firms and market volatility. Pre-IPO Total Factor Productivity is the TFP of IPO firms in the years before going public. The study of the order of going public within an IPO wave only analyzes firms that went public within IPO waves that include at leas 5 same-industry IPOs. All models control for industry (FF-49 level) and IPO-year fixed effect. White standard errors, clustered at the firm level, adjusted for possible correlation within the cluster (Rogers standard errors) are reported. Heteroskedasticity-robust $t$-statistics are reported in parentheses. ***,**, and * indicate significance at the 1,5 , and 10 percent levels, respectively.

\begin{tabular}{|c|c|c|c|c|c|c|c|c|c|c|}
\hline \multirow[t]{2}{*}{ Dependent Variable: } & \multicolumn{10}{|c|}{ Pre-IPO Total Factor Productivity (TFP) } \\
\hline & $(1)$ & $(2)$ & (3) & (4) & $(5$ & (6) & $(7)$ & (8) & (9) & (10) \\
\hline IPONUM/Same Industry Vol. & $\begin{array}{c}-4.143 * * \\
(2.36)\end{array}$ & $\begin{array}{c}-3.439 * * \\
(2.00)\end{array}$ & $\begin{array}{c}-3.419^{* *} \\
(2.02)\end{array}$ & $\begin{array}{c}-3.410^{*} \\
(1.95)\end{array}$ & $\begin{array}{c}-3.083^{*} \\
(1.78)\end{array}$ & & & & & \\
\hline EARLINESS & & & & & & $\begin{array}{c}-0.043^{*} \\
(1.73)\end{array}$ & $\begin{array}{c}-0.056 * * * \\
(2.70)\end{array}$ & $\begin{array}{c}-0.051^{* *} \\
(2.46)\end{array}$ & $\begin{array}{c}-0.049^{*} \\
(1.89)\end{array}$ & $\begin{array}{c}-0.048^{* *} \\
(2.48)\end{array}$ \\
\hline Log (capital stock) & $\begin{array}{c}0.011^{* *} \\
(2.36)\end{array}$ & $\begin{array}{c}0.011 * * \\
(2.32)\end{array}$ & $\begin{array}{c}0.011^{* *} \\
(2.33)\end{array}$ & $\begin{array}{c}0.011^{* *} \\
(2.46)\end{array}$ & $\begin{array}{c}0.011^{* * *} \\
(2.29)\end{array}$ & $\begin{array}{l}0.003 \\
(0.51)\end{array}$ & $\begin{array}{l}0.004 \\
(0.65)\end{array}$ & $\begin{array}{l}0.004 \\
(0.64)\end{array}$ & $\begin{array}{l}0.005 \\
(0.73)\end{array}$ & $\begin{array}{l}0.003 \\
(0.48)\end{array}$ \\
\hline Log (age) & $\begin{array}{l}0.016 \\
(0.90)\end{array}$ & $\begin{array}{l}0.014 \\
(0.77)\end{array}$ & $\begin{array}{l}0.016 \\
(0.90)\end{array}$ & $\begin{array}{l}0.014 \\
(0.79)\end{array}$ & $\begin{array}{l}0.014 \\
(0.76)\end{array}$ & $\begin{array}{c}0.042 * \\
(1.83)\end{array}$ & $\begin{array}{c}0.042^{*} \\
(1.86)\end{array}$ & $\begin{array}{c}0.046^{* *} \\
(1.97)\end{array}$ & $\begin{array}{l}0.044^{*} \\
(1.94)\end{array}$ & $\begin{array}{c}0.048^{* * *} \\
(2.13)\end{array}$ \\
\hline IPO Month Market Return & $\begin{array}{l}-0.421 \\
(1.05)\end{array}$ & & & $\begin{array}{l}-0.161 \\
(0.49)\end{array}$ & & $\begin{array}{l}0.982 \\
(1.36)\end{array}$ & & & $\begin{array}{l}0.220 \\
(0.31)\end{array}$ & \\
\hline IPO Month Market Return (-1) & & & & $\begin{array}{l}-0.568 \\
(1.31)\end{array}$ & & & & & $\begin{array}{l}-0.699 \\
(0.95)\end{array}$ & \\
\hline IPO Month Market Return (-2) & & & & $\begin{array}{l}0.331 \\
(0.91)\end{array}$ & & & & & $\begin{array}{l}-0.492 \\
(0.76)\end{array}$ & \\
\hline IPO Month Market Return $(+1)$ & & & & $\begin{array}{l}0.280 \\
(0.74)\end{array}$ & & & & & $\begin{array}{l}-0.985 \\
(1.47)\end{array}$ & \\
\hline IPO Month Market Return (+2) & & & & $\begin{array}{l}-0.031 \\
(0.08)\end{array}$ & & & & & $\begin{array}{l}-0.698 \\
(0.80)\end{array}$ & \\
\hline
\end{tabular}




\begin{tabular}{|c|c|c|c|c|c|c|c|c|c|c|}
\hline IPO Month Market Volatility & $\begin{array}{c}-8.273 * * \\
(2.39)\end{array}$ & & & & & $\begin{array}{l}0.157 \\
(0.02)\end{array}$ & & & & \\
\hline$\Delta \mathrm{IPO}$ Month Market Volatility & & $\begin{array}{c}-0.326 \\
(0.13)\end{array}$ & & & & & $\begin{array}{l}6.779 \\
(0.65)\end{array}$ & & & \\
\hline$\Delta \mathrm{IPO}$ Month Market Volatility (-1) & & $\begin{array}{l}1.940 \\
(0.38)\end{array}$ & & & & & $\begin{array}{l}12.364 \\
(1.03)\end{array}$ & & & \\
\hline$\Delta \mathrm{IPO}$ Month Market Volatility $(-2)$ & & $\begin{array}{l}-0.794 \\
(0.16)\end{array}$ & & & & & $\begin{array}{l}11.659 \\
(1.58)\end{array}$ & & & \\
\hline$\Delta \mathrm{IPO}$ Month Risk-free Rate & & & $\begin{array}{c}0.061 \text { ** } \\
(2.35)\end{array}$ & & & & & $\begin{array}{l}0.013 \\
(0.24)\end{array}$ & & \\
\hline$\Delta \mathrm{IPO}$ Month Risk-free Rate $(-1)$ & & & $\begin{array}{c}-0.033 \\
(1.03)\end{array}$ & & & & & $\begin{array}{l}-0.136 \\
(1.44)\end{array}$ & & \\
\hline$\Delta$ IPO Month Risk-free Rate $(-2)$ & & & $\begin{array}{l}-0.009 \\
(0.44)\end{array}$ & & & & & $\begin{array}{l}-0.073 \\
(1.18)\end{array}$ & & \\
\hline IPO Month MB Ratio & $\begin{array}{l}0.015 \\
(0.61)\end{array}$ & & & & & $\begin{array}{l}-0.236 \\
(1.11)\end{array}$ & & & & \\
\hline IPO Month MB Ratio (-1) & & & & $\begin{array}{l}0.002 \\
(0.09)\end{array}$ & & & & & $\begin{array}{l}-0.191 \\
(0.79)\end{array}$ & \\
\hline$\triangle I P O$ Month Aggregate ROE & & & & & $\begin{array}{l}-5.246 \\
(0.27)\end{array}$ & & & & & $\begin{array}{c}-17.280 \\
(0.42)\end{array}$ \\
\hline$\Delta \mathrm{IPO}$ Month Aggregate ROE $(+1)$ & & & & & $\begin{array}{l}5.559 \\
(0.21)\end{array}$ & & & & & $\begin{array}{l}12.773 \\
(0.26)\end{array}$ \\
\hline$\Delta \mathrm{IPO}$ Month Aggregate ROE $(+2)$ & & & & & $\begin{array}{l}-6.606 \\
(0.37)\end{array}$ & & & & & $\begin{array}{c}-14.584 \\
(0.39)\end{array}$ \\
\hline$\Delta \mathrm{IPO}$ Month New Firm MB & & & & & $\begin{array}{l}0.021 \\
(0.13)\end{array}$ & & & & & $\begin{array}{l}0.072 \\
(0.32)\end{array}$ \\
\hline$\Delta \mathrm{IPO}$ Month New Firm MB (-1) & & & & & $\begin{array}{l}0.223 \\
(1.16)\end{array}$ & & & & & $\begin{array}{l}0.283 \\
(1.21)\end{array}$ \\
\hline$\triangle \mathrm{IPO}$ Month New Firm MB $(-2)$ & & & & & $\begin{array}{l}0.073 \\
(0.53)\end{array}$ & & & & & $\begin{array}{l}0.110 \\
(0.44)\end{array}$ \\
\hline$\Delta I P O$ Month New Firm Vol & & & & & $\begin{array}{l}1.441 \\
(0.55)\end{array}$ & & & & & $\begin{array}{l}-2.120 \\
(0.36)\end{array}$ \\
\hline$\Delta$ IPO Month New Firm Vol (-1) & & & & & $\begin{array}{l}2.219 \\
(0.68)\end{array}$ & & & & & $\begin{array}{c}11.223 * \\
(1.94)\end{array}$ \\
\hline$\Delta$ IPO Month New Firm Vol (-2) & & & & & $\begin{array}{l}0.308 \\
(0.10)\end{array}$ & & & & & $\begin{array}{r}-0.717 \\
(0.15)\end{array}$ \\
\hline Constant & $\begin{array}{l}0.072 \\
(0.89) \\
\end{array}$ & $\begin{array}{l}0.021 \\
(0.32) \\
\end{array}$ & $\begin{array}{l}0.019 \\
(0.30) \\
\end{array}$ & $\begin{array}{l}0.015 \\
(0.19) \\
\end{array}$ & $\begin{array}{l}0.022 \\
(0.32) \\
\end{array}$ & $\begin{array}{l}-0.233 \\
(0.50) \\
\end{array}$ & $\begin{array}{c}-0.741 * * * * \\
(6.30) \\
\end{array}$ & $\begin{array}{c}-0.740 * * * \\
(6.23) \\
\end{array}$ & $\begin{array}{l}-0.263 \\
(0.51) \\
\end{array}$ & $\begin{array}{c}-0.691 * * * \\
(5.87) \\
\end{array}$ \\
\hline Observations & 3270 & 3270 & 3270 & 3270 & 3269 & 2448 & 2448 & 2448 & 2448 & 2447 \\
\hline R-squared & 0.07 & 0.07 & 0.07 & 0.07 & 0.07 & 0.28 & 0.28 & 0.28 & 0.28 & 0.29 \\
\hline
\end{tabular}




\section{Table A2: Robustness Tests on the Relationship between Post-IPO Operating Performance, Industry Clusteredness of IPOs, and the Order of}

\section{Going Public in an IPO Wave}

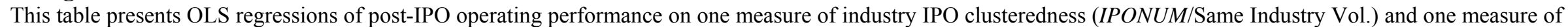

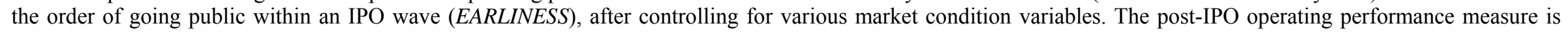

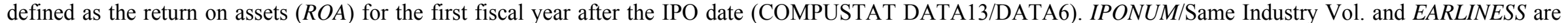

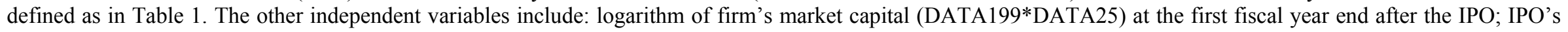

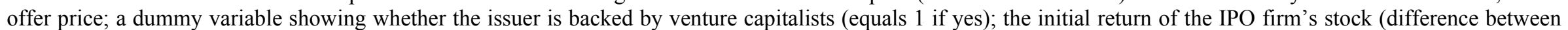

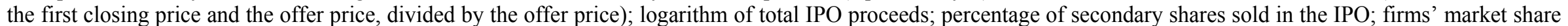

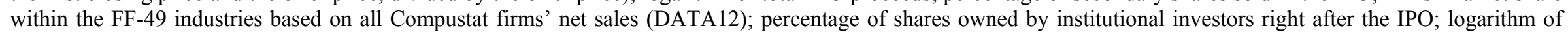

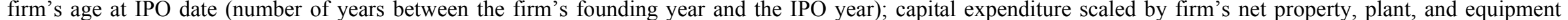

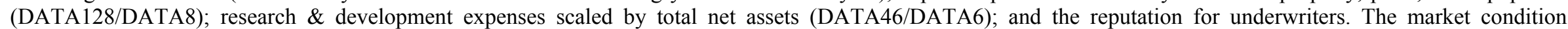

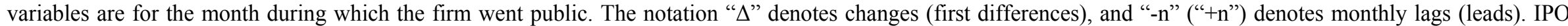

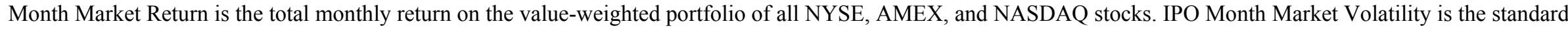

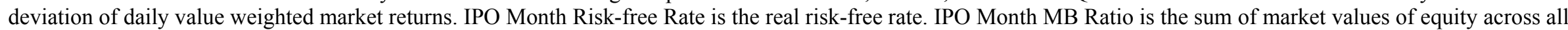

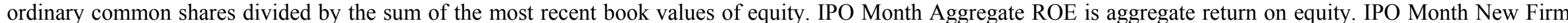

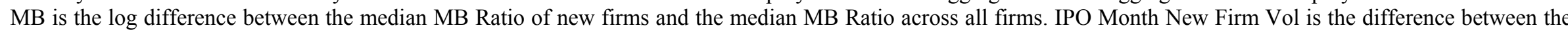

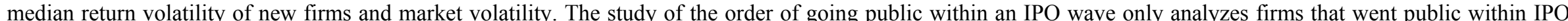

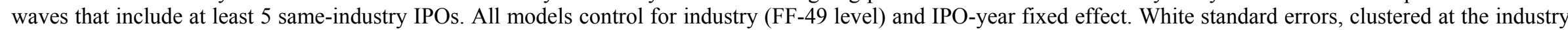

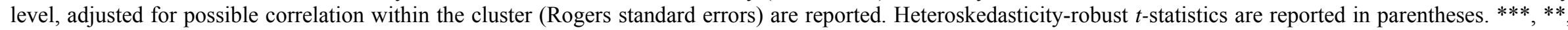
and $*$ indicate significance at the 1,5 , and 10 percent levels, respectively.

\begin{tabular}{|c|c|c|c|c|c|c|c|c|c|c|}
\hline \multirow[t]{2}{*}{ Dependent Variable: } & \multicolumn{10}{|c|}{$\mathrm{ROA}$} \\
\hline & $(1)$ & $(2)$ & $(3)$ & (4) & $(5$ & $(6)$ & $(7)$ & $(8)$ & $(9)$ & $(10)$ \\
\hline IPONUM/Same Industry Vol. & $\begin{array}{c}-0.7576^{* * *} \\
(-3.28)\end{array}$ & $\begin{array}{c}-0.6700 * * * \\
(-3.13)\end{array}$ & $\begin{array}{c}-0.6879 * * * \\
(-3.11)\end{array}$ & $\begin{array}{c}-0.6805 * * * \\
(-2.94)\end{array}$ & $\begin{array}{c}-0.6998 * * * \\
(-3.08)\end{array}$ & & & & & \\
\hline EARLINESS & & & & & & $\begin{array}{c}-0.0087 * * * \\
(-2.86)\end{array}$ & $\begin{array}{c}-0.0075^{* *} \\
(-2.37)\end{array}$ & $\begin{array}{c}-0.0074 * * \\
(-2.37)\end{array}$ & $\begin{array}{c}-0.0066^{* *} \\
(-2.13)\end{array}$ & $\begin{array}{c}-0.0085^{* *} \\
(-2.68)\end{array}$ \\
\hline Log (market cap) & $\begin{array}{c}0.0576^{* * * *} \\
(8.69)\end{array}$ & $\begin{array}{c}0.0572 * * * \\
(8.51)\end{array}$ & $\begin{array}{c}0.0574 * * * \\
(8.52)\end{array}$ & $\begin{array}{c}0.0587 * * * \\
(8.82)\end{array}$ & $\begin{array}{c}0.0570 * * * \\
(8.29)\end{array}$ & $\begin{array}{c}0.0547 * * * \\
(8.38)\end{array}$ & $\begin{array}{l}0.0543 * * * \\
\quad(8.03)\end{array}$ & $\begin{array}{l}0.0545 * * * \\
\quad(8.12)\end{array}$ & $\begin{array}{c}0.0559 * * * \\
(8.57)\end{array}$ & $\begin{array}{c}0.0545 * * * \\
\quad(7.95)\end{array}$ \\
\hline Offer Price & $\begin{array}{c}0.0034 * * \\
(2.52)\end{array}$ & $\begin{array}{c}0.0033 * * \\
(2.59)\end{array}$ & $\begin{array}{c}0.0033 * * \\
(2.53)\end{array}$ & $\begin{array}{c}0.0031 * * \\
(2.40)\end{array}$ & $\begin{array}{l}0.0033 * * \\
(2.49)\end{array}$ & $\begin{array}{c}0.0035^{* *} \\
(2.11)\end{array}$ & $\begin{array}{c}0.0035^{* *} \\
(2.14)\end{array}$ & $\begin{array}{l}0.0034 * * \\
(2.12)\end{array}$ & $\begin{array}{c}0.0033^{* *} \\
(2.11)\end{array}$ & $\begin{array}{c}0.0034 * * \\
(2.08)\end{array}$ \\
\hline Dummy for VC backing & $\begin{array}{c}-0.0279 * * \\
(-2.68)\end{array}$ & $\begin{array}{c}-0.0269 * * \\
(-2.50)\end{array}$ & $\begin{array}{c}-0.0276^{* *} \\
(-2.65)\end{array}$ & $\begin{array}{c}-0.0272 * * \\
(-2.57)\end{array}$ & $\begin{array}{c}-0.0273^{* *} \\
(-2.58)\end{array}$ & $\begin{array}{c}-0.0382 * * * \\
(-3.68)\end{array}$ & $\begin{array}{c}-0.0372 * * * \\
(-3.47)\end{array}$ & $\begin{array}{c}-0.0377 * * * \\
(-3.61)\end{array}$ & $\begin{array}{c}-0.0379 * * * \\
(-3.56)\end{array}$ & $\begin{array}{c}-0.0376^{* * * *} \\
(-3.53)\end{array}$ \\
\hline Initial Return (percent) & $\begin{array}{c}-0.0004 * * * \\
(-5.24)\end{array}$ & $\begin{array}{c}-0.0004 * * * \\
(-4.96)\end{array}$ & $\begin{array}{c}-0.0004 * * * \\
(-4.97)\end{array}$ & $\begin{array}{c}-0.0004 * * * \\
(-5.24)\end{array}$ & $\begin{array}{c}-0.0004 * * * \\
(-4.39)\end{array}$ & $\begin{array}{c}-0.0003 * * * \\
(-3.45)\end{array}$ & $\begin{array}{c}-0.0003 * * * \\
(-3.36)\end{array}$ & $\begin{array}{c}-0.0003 * * * \\
(-3.39)\end{array}$ & $\begin{array}{c}-0.0003 * * * \\
(-3.57)\end{array}$ & $\begin{array}{c}-0.0003 * * * \\
(-3.00)\end{array}$ \\
\hline Log (IPO proceeds) & $\begin{array}{c}-0.0746 * * * \\
(-7.73)\end{array}$ & $\begin{array}{c}-0.0731 * * * \\
(-7.78)\end{array}$ & $\begin{array}{c}-0.0732 * * * \\
(-7.66)\end{array}$ & $\begin{array}{c}-0.0745 * * * \\
(-7.98)\end{array}$ & $\begin{array}{c}-0.0731 * * * \\
(-7.22)\end{array}$ & $\begin{array}{c}-0.0832 * * * \\
(-6.96)\end{array}$ & $\begin{array}{c}-0.0814 * * * \\
(-7.02)\end{array}$ & $\begin{array}{c}-0.0816^{* * * *} \\
(-6.91)\end{array}$ & $\begin{array}{c}-0.0831 * * * \\
(-7.14)\end{array}$ & $\begin{array}{c}-0.0824 * * * \\
(-6.99)\end{array}$ \\
\hline Percent of Secondary Shares & $\begin{array}{l}0.2029 * * * \\
(7.09)\end{array}$ & $\begin{array}{c}0.2029 * * * \\
(6.99)\end{array}$ & $\begin{array}{c}0.2020 * * * \\
(7.03)\end{array}$ & $\begin{array}{c}0.2042 * * * \\
(7.03)\end{array}$ & $\begin{array}{l}0.2028 * * * \\
(6.90)\end{array}$ & $\begin{array}{l}0.2358 * * * \\
\quad(7.25)\end{array}$ & $\begin{array}{c}0.2368^{* * * *} \\
\quad(7.23)\end{array}$ & $\begin{array}{c}0.2358 * * * \\
\quad(7.17)\end{array}$ & $\begin{array}{l}0.2374 * * * \\
\quad(7.20)\end{array}$ & $\begin{array}{c}0.2370 * * * \\
\quad(7.21)\end{array}$ \\
\hline
\end{tabular}




\begin{tabular}{|c|c|c|c|c|c|c|c|c|c|c|}
\hline Market Share & $\begin{array}{c}-0.1739 \\
(-0.79)\end{array}$ & $\begin{array}{c}-0.2574 \\
(-1.09)\end{array}$ & $\begin{array}{c}-0.2592 \\
(-1.13)\end{array}$ & $\begin{array}{c}-0.2261 \\
(-1.04)\end{array}$ & $\begin{array}{c}-0.2335 \\
(-1.01)\end{array}$ & $\begin{array}{c}0.3710 \\
(0.68)\end{array}$ & $\begin{array}{l}0.3066 \\
(0.53)\end{array}$ & $\begin{array}{l}0.2877 \\
(0.50)\end{array}$ & $\begin{array}{c}0.2809 \\
(0.51)\end{array}$ & $\begin{array}{l}0.3168 \\
(0.56)\end{array}$ \\
\hline Percent of Institutional Holding & $\begin{array}{c}0.1210^{* * *} \\
(6.20)\end{array}$ & $\begin{array}{c}0.1197 * * * \\
(6.05)\end{array}$ & $\begin{array}{c}0.1204 * * * \\
(5.92)\end{array}$ & $\begin{array}{c}0.1185^{* * * *} \\
(6.36)\end{array}$ & $\begin{array}{c}0.1201 * * * \\
(5.90)\end{array}$ & $\begin{array}{c}0.1381 * * * \\
(4.41)\end{array}$ & $\begin{array}{c}0.1390 * * * \\
(4.38)\end{array}$ & $\begin{array}{c}0.1396^{* * * *} \\
(4.34)\end{array}$ & $\begin{array}{c}0.1367^{* * *} \\
(4.52)\end{array}$ & $\begin{array}{c}0.1400^{* * * *} \\
(4.41)\end{array}$ \\
\hline Log (firm age at IPO date) & $\begin{array}{c}0.0312 * * * \\
(5.78)\end{array}$ & $\begin{array}{c}0.0314^{* * * *} \\
(5.78)\end{array}$ & $\begin{array}{c}0.0312^{* * * *} \\
(5.71)\end{array}$ & $\begin{array}{c}0.0311^{* * * *} \\
(5.74)\end{array}$ & $\begin{array}{c}0.0313 * * * \\
(5.70)\end{array}$ & $\begin{array}{c}0.0315 * * * \\
(5.42)\end{array}$ & $\begin{array}{c}0.0315^{* * *} * \\
(5.41)\end{array}$ & $\begin{array}{c}0.0315^{* * * *} \\
(5.38)\end{array}$ & $\begin{array}{c}0.0316^{* * * *} \\
(5.52)\end{array}$ & $\begin{array}{c}0.0316^{* * *} \\
(5.49)\end{array}$ \\
\hline CapEx/PPE & $\begin{array}{c}-0.0638^{* * * *} \\
(-4.93)\end{array}$ & $\begin{array}{c}-0.0638 * * * \\
(-4.91)\end{array}$ & $\begin{array}{c}-0.0633 * * * \\
(-4.93)\end{array}$ & $\begin{array}{c}-0.0644 * * * \\
(-4.91)\end{array}$ & $\begin{array}{c}-0.0642 * * * \\
(-4.91)\end{array}$ & $\begin{array}{c}-0.0820 * * * \\
(-5.75)\end{array}$ & $\begin{array}{c}-0.0831 * * * \\
(-5.79)\end{array}$ & $\begin{array}{c}-0.0823^{* * *} \\
(-5.67)\end{array}$ & $\begin{array}{c}-0.0828 * * * \\
(-5.71)\end{array}$ & $\begin{array}{c}-0.0828 * * * \\
(-5.56)\end{array}$ \\
\hline R\&D/Assets & $\begin{array}{c}-1.0508^{* * * *} \\
(-8.94)\end{array}$ & $\begin{array}{c}-1.0537 * * * \\
(-9.06)\end{array}$ & $\begin{array}{c}-1.0530^{* * *} \\
(-8.91)\end{array}$ & $\begin{array}{c}-1.0538 * * * \\
(-9.01)\end{array}$ & $\begin{array}{c}-1.0538 * * * \\
(-8.82)\end{array}$ & $\begin{array}{c}-1.0609 * * * \\
(-8.69)\end{array}$ & $\begin{array}{c}-1.0661 * * * \\
(-8.85)\end{array}$ & $\begin{array}{c}-1.0636^{* * *} \\
(-8.71)\end{array}$ & $\begin{array}{c}-1.0647 * * * \\
(-8.76)\end{array}$ & $\begin{array}{c}-1.0625^{* * *} * \\
(-8.66)\end{array}$ \\
\hline Underwriter Reputation & $\begin{array}{c}0.0093 * * * \\
(4.93)\end{array}$ & $\begin{array}{c}0.0092 * * * \\
(4.76)\end{array}$ & $\begin{array}{c}0.0093^{* * * *} \\
(4.86)\end{array}$ & $\begin{array}{c}0.0092 * * * \\
(4.90)\end{array}$ & $\begin{array}{c}0.0093 * * * \\
(4.75)\end{array}$ & $\begin{array}{c}0.0112 * * * \\
(4.94)\end{array}$ & $\begin{array}{c}0.0111 * * * \\
(4.91)\end{array}$ & $\begin{array}{c}0.0112 * * * \\
(4.93)\end{array}$ & $\begin{array}{c}0.0110^{* * *} \\
(4.96)\end{array}$ & $\begin{array}{c}0.0113^{* * *} \\
(5.02)\end{array}$ \\
\hline IPO Month Market Return & $\begin{array}{c}-0.2977 * * * \\
(-4.19)\end{array}$ & & & $\begin{array}{c}-0.1004 \\
(-1.51)\end{array}$ & & $\begin{array}{c}-0.2847 * * * \\
(-4.26)\end{array}$ & & & $\begin{array}{c}-0.0268 \\
(-0.35)\end{array}$ & \\
\hline IPO Month Market Return (-1) & & & & $\begin{array}{c}0.2817 * * * \\
(3.40)\end{array}$ & & & & & $\begin{array}{c}0.3184 * * * \\
(3.08)\end{array}$ & \\
\hline IPO Month Market Return (-2) & & & & $\begin{array}{l}0.1347 \\
(1.54)\end{array}$ & & & & & $\begin{array}{c}0.1353 \\
(1.16)\end{array}$ & \\
\hline IPO Month Market Return (+1) & & & & $\begin{array}{l}-0.0811 \\
(-1.19)\end{array}$ & & & & & $\begin{array}{c}0.0078 \\
(0.12)\end{array}$ & \\
\hline IPO Month Market Return (+2) & & & & $\begin{array}{l}-0.0539 \\
(-0.67)\end{array}$ & & & & & $\begin{array}{c}-0.0493 \\
(-0.62)\end{array}$ & \\
\hline IPO Month Market Volatility & $\begin{array}{c}-1.7504 * * \\
(-2.15)\end{array}$ & & & & & $\begin{array}{l}-1.2646 \\
(-1.13)\end{array}$ & & & & \\
\hline$\Delta$ IPO Month Market Volatility & & $\begin{array}{c}1.2308^{*} \\
(1.95)\end{array}$ & & & & & $\begin{array}{l}1.0163 \\
(1.29)\end{array}$ & & & \\
\hline$\Delta$ IPO Month Market Volatility (-1) & & $\begin{array}{c}-0.2314 \\
(-0.21)\end{array}$ & & & & & $\begin{array}{c}0.2348 \\
(0.25)\end{array}$ & & & \\
\hline$\Delta$ IPO Month Market Volatility (-2) & & $\begin{array}{l}-0.2321 \\
(-0.27)\end{array}$ & & & & & $\begin{array}{l}-0.3473 \\
(-0.45)\end{array}$ & & & \\
\hline$\Delta$ IPO Month Risk-free Rate & & & $\begin{array}{l}0.0049 \\
(0.54)\end{array}$ & & & & & $\begin{array}{c}0.0092 \\
(0.97)\end{array}$ & & \\
\hline$\Delta$ IPO Month Risk-free Rate (-1) & & & $\begin{array}{c}-0.0149 \\
(-1.44)\end{array}$ & & & & & $\begin{array}{c}-0.0092 \\
(-0.98)\end{array}$ & & \\
\hline$\Delta$ IPO Month Risk-free Rate (-2) & & & $\begin{array}{c}0.0133^{*} \\
(1.81)\end{array}$ & & & & & $\begin{array}{c}0.0124^{*} \\
(1.82)\end{array}$ & & \\
\hline IPO Month MB Ratio & $\begin{array}{c}0.0606 * * * \\
(3.14)\end{array}$ & & & & & $\begin{array}{c}0.0747 * * * \\
(3.73)\end{array}$ & & & & \\
\hline IPO Month MB Ratio (-1) & & & & $\begin{array}{c}0.0069 \\
(0.33)\end{array}$ & & & & & $\begin{array}{l}0.0158 \\
(0.81)\end{array}$ & \\
\hline
\end{tabular}


$\Delta$ IPO Month Aggregate ROE

$-6.0599$

$(-1.62)$

4.2175

$(0.88)$

$\triangle \mathrm{IPO}$ Month Aggregate ROE (+2)

$-3.4987$

$(-1.13)$

$\triangle I P O$ Month New Firm MB

$-0.0035$

$(-0.11)$

$\Delta$ IPO Month New Firm MB (-1)

0.0314

(1.51)

$-0.0008$

$(-0.03)$

$\Delta$ IPO Month New Firm Vol

0.1269

(0.16)

0.1629

$\Delta$ IPO Month New Firm Vol (-1)

$(0.21)$

0.0113

0.0113
$(0.53)$

0.0494

$(0.05)$

$-0.4943$

0.0819

$(-0.62)$

$\Delta$ IPO Month New Firm Vol (-2)

$(0.12)$

$-0.1621$

$(-0.27)$

Constant

$\begin{array}{cccc}-0.1869 * * * & -0.0615^{*} & -0.0546 & -0.0804\end{array}$

$-0.0620^{*}$ $(-3.31) \quad(-1.79)$ $(-1.60) \quad(-1.24)$

Observations

3256

$\begin{array}{lll}3,256 & 3,256 & 3,256 \\ 0.555 & 0.556 & 0.557\end{array}$

$(-1.85)$

$-0.1390^{*}$

$-0.1626^{* *}-0.1$ $(-1.98)$ $(-2.64)$

$(-2.75) \quad(-2.34)$

$(-2.79)$

R-squared

$\begin{array}{lllll}0.556 & 0.555 & 0.556 & 0.557 & 0.555\end{array}$

$\begin{array}{llll}0.583 & 0.581 & 0.582 & 0.583\end{array}$ 
Table A3: Long-term Post-IPO Operating Performance, Industry Clusteredness of IPOs, and the Order of Going Public in an IPO Wave This table presents OLS regressions of long-term post-IPO operating performance on the three measures of industry IPO clusteredness and the three measures of the order of going public within an IPO wave. The long-term post-IPO operating performance is defined as the average return on assets (ROA) (COMPUSTAT DATA13/DATA6) for the first three fiscal years after the IPO. The three industry IPO clusteredness measures and the three measures for the order of going public within an IPO wave are defined as in Table 1. Other independent variables include: logarithm of firm's market capital (DATA199*DATA25) at the first fiscal year end after the IPO; IPO's offer price; a dummy variable showing whether the issuer is backed by venture capitalists (equals 1 if yes); the initial return of the IPO firm's stock (difference between the first closing price and the offer price, divided by the offer price); logarithm of total IPO proceeds; percentage of secondary shares sold in the IPO; firms' market share within the FF-49 industries based on all Compustat firms' net sales (DATA12); percentage of shares owned by institutional investors right after the IPO; logarithm of firm's age at IPO date (number of years between the firm's founding year and the IPO year); capital expenditure scaled by firm's net property, plant, and equipment (DATA128/DATA8); research \& development expenses scaled by total net assets (DATA46/DATA6); and the reputation for underwriters. IPO Month Market return is the total monthly return on the value-weighted portfolio of all NYSE, AMEX, and NASDAQ stocks for the month during which the firm went public. IPO Month Market volatility is computed as the standard deviation of daily value weighted market returns for the month during which the firm went public. IPO Month MB Ratio is the sum of market values of equity across all ordinary common shares divided by the sum of the most recent book values of equity for the month during which the firm went public. The first three columns in each panel analyze all firms that went public during the sample period, while the latter three columns analyze only firms that went public within IPO waves that include at least 5 same-industry IPOs. All models control for industry (FF-49 level) and IPO-year fixed effect. White standard errors, clustered at the industry level, adjusted for possible correlation within the cluster (Rogers standard errors) are reported. Heteroskedasticity-robust $t$-statistics are reported in parentheses. ${ }^{* * *}, * *$, and * indicate significance at the 1,5 , and 10 percent levels, respectively.

\begin{tabular}{|c|c|c|c|c|c|c|}
\hline \multirow[t]{2}{*}{ Dependent Variable: } & \multicolumn{6}{|c|}{ 3-year Average ROA } \\
\hline & $(1)$ & (2) & (3) & (4) & (5) & (6) \\
\hline IPONUM & $\begin{array}{c}-0.0023 * * * \\
(-3.82)\end{array}$ & & & & & \\
\hline IPONUM/Same Industry Vol. & & $\begin{array}{c}-0.8545^{* * *} \\
(-2.99)\end{array}$ & & & & \\
\hline IPONUM/Same Window Vol. & & & $\begin{array}{c}-0.2734 * * * \\
(-3.84)\end{array}$ & & & \\
\hline EARLINESS & & & & $\begin{array}{c}-0.0104 * * \\
(-2.23)\end{array}$ & & \\
\hline ORDER / Median ORDER & & & & & $\begin{array}{c}-0.0209^{* *} \\
(-2.17)\end{array}$ & \\
\hline $\log (O R D E R)$ & & & & & & $\begin{array}{c}-0.0113 * * \\
(-2.56)\end{array}$ \\
\hline Log (market cap) & $\begin{array}{c}0.0670 * * * \\
(7.60)\end{array}$ & $\begin{array}{c}0.0661 * * * \\
(7.63)\end{array}$ & $\begin{array}{c}0.0665 * * * \\
(7.59)\end{array}$ & $\begin{array}{c}0.0649 * * * \\
(7.06)\end{array}$ & $\begin{array}{c}0.0650 * * * \\
(7.07)\end{array}$ & $\begin{array}{c}0.0647 * * * \\
(7.00)\end{array}$ \\
\hline Offer Price & $\begin{array}{c}0.0044 * * \\
(2.48)\end{array}$ & $\begin{array}{c}0.0045^{* *} \\
(2.51)\end{array}$ & $\begin{array}{c}0.0045^{* *} \\
(2.47)\end{array}$ & $\begin{array}{c}0.0049 * * \\
(2.18)\end{array}$ & $\begin{array}{c}0.0049 * * \\
(2.18)\end{array}$ & $\begin{array}{c}0.0051^{* *} \\
(2.32)\end{array}$ \\
\hline Dummy for VC backing & $\begin{array}{c}-0.0158 \\
(-1.62)\end{array}$ & $\begin{array}{c}-0.0180 * \\
(-1.84)\end{array}$ & $\begin{array}{c}-0.0162 * \\
(-1.70)\end{array}$ & $\begin{array}{c}-0.0278 * * * \\
(-3.06)\end{array}$ & $\begin{array}{c}-0.0279 * * * \\
(-3.07)\end{array}$ & $\begin{array}{c}-0.0273 * * * \\
(-3.00)\end{array}$ \\
\hline Initial Return (percent) & $-0.0003 * * *$ & $-0.0003 * * *$ & $-0.0003 * * *$ & $-0.0002 * * *$ & $-0.0003 * * *$ & $-0.0002 * * *$ \\
\hline
\end{tabular}


Log (IPO proceeds)

Percent of Secondary Shares

IPO Month Market Return

IPO Month Market Volatility

IPO Month MB Ratio

Market share

Percent of Institutional Holding

Log (firm age at IPO date)

CapEx/PPE

R\&D/Assets

Underwriter Reputation

Constant

Observations

R-squared

\begin{tabular}{|c|c|c|c|c|c|}
\hline$(-5.36)$ & $(-5.54)$ & $(-5.32)$ & $(-3.17)$ & $(-3.21)$ & $(-3.04)$ \\
\hline $0.0906 * * *$ & $-0.0885^{* * *}$ & $-0.0902 * * *$ & $-0.0997 * * *$ & $-0.0998 * * *$ & $-0.1000 * * *$ \\
\hline$(-6.86)$ & $(-6.91)$ & $(-6.88)$ & $(-6.15)$ & $(-6.17)$ & $(-6.14)$ \\
\hline $0.2078 * * *$ & $0.2078 * * *$ & $0.2070 * * *$ & $0.2464 * * *$ & $0.2461 * * *$ & $0.2484 * * *$ \\
\hline$(7.06)$ & $(6.90)$ & $(6.88)$ & $(6.89)$ & (6.92) & $(7.08)$ \\
\hline $0.4018 * * *$ & $-0.3877 * * *$ & $-0.3752 * * *$ & $-0.3852 * * *$ & $-0.3987 * * *$ & $-0.4053 * * *$ \\
\hline$(-4.04)$ & $(-3.71)$ & $(-3.83)$ & $(-2.77)$ & $(-2.81)$ & $(-2.88)$ \\
\hline-1.2128 & -1.1742 & -0.9814 & -0.7767 & -0.8895 & -0.8801 \\
\hline$(-1.22)$ & $(-1.15)$ & $(-0.98)$ & $(-0.38)$ & $(-0.43)$ & $(-0.43)$ \\
\hline $0.0884 * *$ & $0.0817 * *$ & $0.0683 * *$ & $0.1009 * * *$ & $0.1012 * * *$ & $0.1031 * * *$ \\
\hline$(2.66)$ & $(2.53)$ & $(2.08)$ & (3.30) & (3.36) & (3.33) \\
\hline-0.1460 & -0.1899 & -0.1570 & 0.4800 & 0.4748 & 0.4076 \\
\hline$(-0.92)$ & $(-1.08)$ & $(-0.96)$ & (1.19) & (1.17) & $(0.99)$ \\
\hline $0.1404 * * *$ & $0.1445 * * *$ & $0.1420 * * *$ & $0.1562 * * *$ & $0.1560 * * *$ & $0.1567 * * *$ \\
\hline$(8.12)$ & $(8.37)$ & $(8.32)$ & $(5.37)$ & $(5.33)$ & $(5.46)$ \\
\hline $0.0320 * * *$ & $0.0314 * * *$ & $0.0318 * * *$ & $0.0303 * * *$ & $0.0303 * * *$ & $0.0307 * * *$ \\
\hline$(5.15)$ & $(5.24)$ & $(5.22)$ & $(5.84)$ & (5.79) & $(5.85)$ \\
\hline $0.1102 * * *$ & $-0.1130 * * *$ & $-0.1102 * * *$ & $-0.1234 * * *$ & $-0.1237 * * *$ & $-0.1215 * * *$ \\
\hline$(-7.62)$ & $(-7.98)$ & $(-7.62)$ & $(-8.29)$ & $(-8.31)$ & $(-7.95)$ \\
\hline $1.1282 * * *$ & $-1.1374 * * *$ & $-1.1225^{* * *}$ & $-1.1596^{* * *}$ & $-1.1593 * * *$ & $-1.1455^{* * *}$ \\
\hline$(-8.89)$ & $(-9.06)$ & $(-8.96)$ & $(-8.47)$ & $(-8.41)$ & $(-8.41)$ \\
\hline $0.0149 * * *$ & $0.0145 * * *$ & $0.0147 * * *$ & $0.0153 * * *$ & $0.0153 * * *$ & $0.0153 * * *$ \\
\hline$(5.73)$ & $(5.54)$ & $(5.76)$ & $(5.02)$ & (4.99) & $(5.14)$ \\
\hline $0.3575 * * *$ & $-0.3164 * * *$ & $-0.3072 * * *$ & $-0.2877 * * *$ & $-0.2846^{* * *}$ & $-0.2850 * * *$ \\
\hline$(-4.29)$ & $(-3.86)$ & $(-3.71)$ & $(-3.28)$ & $(-3.26)$ & $(-3.19)$ \\
\hline 3256 & 3256 & 3256 & 2320 & 2320 & 2320 \\
\hline 0.531 & 0.529 & 0.531 & 0.555 & 0.555 & 0.555 \\
\hline
\end{tabular}




\section{Internet Appendix B: Propositions and Proofs regarding Equilibria Presented in the Main Body of the Paper (Not to be Published)}

Proposition 1 (IPO waves even without a productivity shock) When the magnitude of the shock is moderate $\left(A_{1}-A_{2}<\Delta A \leq \Delta A_{L}\right)$, the probability of the shock is large, the issuing cost is small, and the existing productivity levels of firm 1 and firm 2 are high, both firms will go public before the realization of a productivity shock (at time 1).

Proposition 2 (IPO waves only with a productivity shock) When the magnitude of a potential shock is large $\left(\triangle A>\Delta A_{L}\right)$, in addition to the PBE in Proposition 1, we have two more possible equilibria:

(i) When the existing market share of firm 1 is moderately large $\left(m \geq\left(2+s-\sqrt{s^{2}+4}\right) /(2 s)\right)$, and the existing productivity levels of firm 1 and firm 2 are low, both firms will remain private before the realization of a productivity shock (at time 1) and go public only upon the realization of a shock (at time 2).

(ii) When the existing market share of firm 1 is small $\left(m<\left(2+s-\sqrt{s^{2}+4}\right) /(2 s)\right)$, the existing productivity of firm 1 is high, and the existing productivity of firm 2 is low, firm 1 will go public before the realization of a productivity shock (at time 1) and firm 2 will go public only upon the realization of a shock (at time 2).

Proposition 3 (IPOs off the wave) When the magnitude of a potential shock is not too large ( $\triangle A<$ $\triangle A_{H}$ ), we have two additional equilibria besides the above three PBEs:

(i) When the probability of a potential shock is low, the existing market share of firm 1 is small $\left(m<\left(2+s-\sqrt{s^{2}+4}\right) /(2 s)\right)$, the existing productivity of firm 1 is low, and the issuing cost is large, firm 1 will go public only upon the realization of a shock (at time 2) and firm 2 will remain private throughout.

(ii) When the probability of a potential shock is high, the existing market share of firm 1 is moderately large $\left(m \geq\left(2+s-\sqrt{s^{2}+4}\right) /(2 s)\right)$, the existing productivity of firm 1 is high, and the issuing cost is small, firm 1 will go public before the realization of a productivity shock (at time 1) and firm 2 will remain private throughout. 


\begin{tabular}{|c|c|c|c|}
\hline Firm 1's market share & Firm 2's market share & Firm 1's market share & Firm 2's market share \\
\hline Go public & Go public & Remain public & Remain public \\
\hline$m$ & $1-m$ & $m$ & $1-m$ \\
\hline \multirow{4}{*}{$\begin{array}{l}\text { Go public } \\
m_{b} \equiv m+(1-m) s m\end{array}$} & \multirow{4}{*}{$\begin{array}{l}\text { Remain private } \\
1-m_{b} \equiv(1-m)(1-s m)\end{array}$} & Remain public & Go public \\
\hline & & $m_{b}$ & $1-m_{b}$ \\
\hline & & Remain public & Remain private \\
\hline & & $m_{b}+\left(1-m_{b}\right) s m_{b}$ & $\left(1-m_{b}\right)\left(1-s m_{b}\right)$ \\
\hline \multirow{4}{*}{$\begin{array}{l}\text { Remain private } \\
m_{c} \equiv m-(1-m) s m\end{array}$} & \multirow{4}{*}{$\begin{array}{l}\text { Go public } \\
1-m_{c} \equiv(1-m)(1+s m)\end{array}$} & Go public & Remain public \\
\hline & & $m_{c}$ & $1-m_{c}$ \\
\hline & & Remain private & Remain public \\
\hline & & $m_{c}-\left(1-m_{c}\right) s m_{c}$ & $\left(1-m_{c}\right)\left(1+s m_{c}\right)$ \\
\hline \multirow{8}{*}{$\begin{array}{l}\text { Remain private } \\
m\end{array}$} & \multirow{8}{*}{$\begin{array}{l}\text { Remain private } \\
1-m\end{array}$} & Go public & Go public \\
\hline & & $m$ & $1-m$ \\
\hline & & Go public & Remain private \\
\hline & & $m_{b}$ & $1-m_{b}$ \\
\hline & & Remain private & Go public \\
\hline & & $m_{c}$ & $1-m_{c}$ \\
\hline & & Remain private & Remain private \\
\hline & & $m$ & $1-m$ \\
\hline
\end{tabular}

Figure 3: Evolution of market share and its relationship to the going public decision

Proof of Propositions 1, 2, and 3: Since these three propositions all involve solving the perfect Bayesian equilibrium (PBE) for the model, we put the proofs of them together. We first prove the more complicated case of purely idiosyncratic productivity shocks (studied in Appendix B) and then generalize the proofs to the case of industry-wide productivity shocks. After solving for the possible PBEs, we characterize the conditions under which they can occur.

Part (a): Solving for all the PBEs in the model.

To make our exposition simpler, we define the following operating profit functions per unit of 
market share:

$$
\begin{aligned}
& \pi_{1} \equiv A_{1}\left(k_{1 L}^{e}\right)^{\gamma}-c k_{1 L}^{e}=\left(A_{1}\right)^{\frac{1}{1-\gamma}} c^{\frac{\gamma}{\gamma-1}} \gamma^{\frac{\gamma}{1-\gamma}}(1-\gamma) \\
& \pi_{2} \equiv A_{2}\left(k_{2 L}^{e}\right)^{\gamma}-c k_{2 L}^{e}=\left(A_{2}\right)^{\frac{1}{1-\gamma}} c^{\frac{\gamma}{\gamma-1}} \gamma^{\frac{\gamma}{1-\gamma}}(1-\gamma) \\
& \pi_{2 H} \equiv A_{2 H}\left(k_{2 H}^{e}\right)^{\gamma}-c k_{2 H}^{e}=\left(A_{2 H}\right)^{\frac{1}{1-\gamma}} c^{\frac{\gamma}{\gamma-1}} \gamma^{\frac{\gamma}{1-\gamma}}(1-\gamma) \\
& \pi_{1 H}^{I P O} \equiv A_{1 H}\left(k_{1 H}^{e}\right)^{\gamma}-c k_{1 H}^{e}=\left(A_{1 H}\right)^{\frac{1}{1-\gamma}} c^{\frac{\gamma}{\gamma-1}} \gamma^{\frac{\gamma}{1-\gamma}}(1-\gamma) \\
& \pi_{1 H}^{P R}\left(m_{1}^{I I}\right) \equiv A_{1 H}\left(K_{0} / m_{1}^{I I}\right)^{\gamma}-c\left(K_{0} / m_{1}^{I I}\right)
\end{aligned}
$$

where $\pi_{1}$ and $\pi_{2}$ are the per-unit-market-share operating profits for firm 1 and firm 2 respectively if they do not experience the productivity shock; $\pi_{2 H}$ is the per-unit-market-share operating profit for firm 2 if it gets the shock (whether or not it is public); $\pi_{1 H}^{I P O}$ is the per-unit-market-share operating profit for firm 1 if it gets the shock and goes public; and $\pi_{1 H}^{P R}\left(m_{1}^{I I}\right)$, which depends on the level of $m_{1}^{I I}$, is firm 1's per-unit-market-share operating profit if it gets the shock but chooses to remain private. We then have the following relationship:

$$
\left\{\begin{array}{l}
\pi_{2}<\pi_{1}<\pi_{1 H}^{P R}\left(m_{1}^{I I}\right)<\pi_{1 H}^{I P O} \\
\pi_{2}<\pi_{2 H}<\pi_{1 H}^{P R}\left(m_{1}^{I I}\right)<\pi_{1 H}^{I P O}
\end{array}\right.
$$

Moreover, we have made the following assumption:

$$
m_{1}^{I I} \pi_{1 H}^{I P O}-m_{1}^{I I} \pi_{1 H}^{P R}\left(m_{1}^{I I}\right)>B \text {, for } m_{b}+s m_{b}\left(1-m_{b}\right) \geq m_{1}^{I I} \geq m_{c}-s m_{c}\left(1-m_{c}\right),
$$

where the left handside denotes the benefit of going public (even if it does not enhance product market competitiveness) and the right handside is the cost.

Finally, we have also assumed that without productivity shocks, the maximum possible benefit each firm can derive from additional market share will be less than the cost of going public:

$$
\begin{aligned}
& B>\left[m_{b}+s m_{b}\left(1-m_{b}\right)-m\right] \pi_{1} . \\
& B>\left[\left(1-m_{c}\right)\left(1+s m_{c}\right)-(1-m)\right] \pi_{2} .
\end{aligned}
$$

To solve for PBE, we use backward induction. Let $\left(a_{1}, a_{2}\right)$ denote the strategies adopted by firm 1 and firm 2 respectively. $a_{i}$ can be either "I $P O$ " (meaning "go public" or "remain public") or "PR" (meaning "remain private"). Then the strategy profile at time 1 can be one of the following four: (IPO, IPO), (IPO,PR), (PR,IPO), $(P R, P R)$. According to Figure 2 , if the time 1 strategy profile is ( $I P O, I P O)$, then the market share for firm 1 and 2 is $(m, 1-m)$ at time 2 and the game is over because both firms cannot switch back to the private status. If the time 1 strategy profile is $(I P O, P R)$, then at time 2 , firm 2's market share will be $\left(1-m_{b}\right)\left(1-s m_{b}\right)$ if it stays private and $1-m_{b}$ if it goes public. The incremental market share it gets by IPO is $\left(1-m_{b}\right) s m_{b}$. Similarly, if the time 1 strategy profile is $(P R, I P O)$, the incremental market share for firm 1 to go public rather than remaining private at time 2 is $\left(1-m_{c}\right) s m_{c}$. Lastly, if the time 1 strategy profile is $(P R, P R)$, then either firm 1 or firm 2's incremental market share by IPO (given rival's strategy) at time 2 is $(1-m) s m$. Hence, the firms will compare the incremental profit by IPO to the issuing cost, $B$, to make their going public decision. Since we will make use of these incremental market 
share, we need to rank them. Simple calculation yields

$$
\left\{\begin{array}{l}
\left(1-m_{b}\right) m_{b}>(1-m) m \Leftrightarrow m<\frac{2+s-\sqrt{s^{2}+4}}{2 s}\left(<\frac{1}{2}\right) \\
\left(1-m_{c}\right) m_{c}>(1-m) m \Leftrightarrow m>\frac{s-2+\sqrt{s^{2}+4}}{2 s}\left(>\frac{1}{2}\right) \\
\left(1-m_{b}\right) m_{b}>\left(1-m_{c}\right) m_{c} \Leftrightarrow m<\frac{1}{2}
\end{array} .\right.
$$

Since this model involves discrete choice of firms, we need to examine the parameter values in different ranges.

Case (i) $\Delta A<A_{1}-A_{2}$

(I) $0<m<\frac{2+s-\sqrt{s^{2}+4}}{2 s} \Rightarrow\left(1-m_{b}\right) m_{b}>(1-m) m>\left(1-m_{c}\right) m_{c}$

By conditions (4) and (5), we then have:

$$
B>(1-m) s m \pi_{2 H}>(1-m) s m \pi_{1}>(1-m) s m \pi_{2},
$$

which means that if the time 1 strategy profile is $(P R, P R)$, firm 2 will continue to remain private at time 2. Firm 1 will not go public at time 2 if it does not get the productivity shock. However, if firm 1 gets the productivity shock, it pays off to go public. This is because given firm 2 IPO at time 2, firm 1 with higher productivity will gain net profit $m \pi_{1}^{I P O}-m_{c} \pi_{1}^{P R}\left(m_{c}\right)$ by also going public. Similarly, given firm 2 remaining private at time 2, firm 1 with higher productivity will gain $m_{b} \pi_{1}^{I P O}-m \pi_{1}^{P R}(m)$ by going public. Given assumption (3) in the main text, and the fact that $m_{1}^{I I} \pi_{1}^{P R}\left(m_{1}^{I I}\right)$ is increasing in $m_{1}^{I I}$ (proof of this is straightforward and thus omitted here), it directly follows that going public is a strictly dominant strategy for firm 1 at time 2 once it gets the productivity shock. Similarly, since $\pi_{2 H}<\pi_{1}$ and $\left[m_{b}+s m_{b}\left(1-m_{b}\right)-m\right] \pi_{1}<B$, we have:

$$
B>\left(1-m_{b}\right) s m_{b} \pi_{2 H}>\left(1-m_{b}\right) s m_{b} \pi_{2},
$$

which shows that remaining private is also dominant for firm 2 at time 2 if firm 1 has already gone public at time 1. Last, (3), (4), and (5) determine that:

$$
m_{c} \pi_{1 H}^{I P O}-\left(m_{c}-s m_{c}\left(1-m_{c}\right)\right) \pi_{1 H}^{P R}\left(m_{c}-s m_{c}\left(1-m_{c}\right)\right)>B>s m_{c}\left(1-m_{c}\right) \pi_{1} .
$$

In this case, if the time 1 strategy profile is $(P R, I P O)$ and firm 1 has the productivity shock at time 2, it will go public. Otherwise it will remain private. Therefore, the expected payoffs for the four time 1 strategy profiles can be written as:

$$
\left\{\begin{array}{l}
(I P O, I P O):\left(x_{1}, y_{1}\right) \\
(I P O, P R):\left(x_{2}, y_{2}\right) \\
(P R, I P O):\left(x_{3}, y_{3}\right) \\
(P R, P R):\left(x_{4}, y_{4}\right)
\end{array}\right.
$$


where

$$
\left\{\begin{array}{l}
x_{1}=m\left(p \pi_{1 H}^{I P O}+(1-p) \pi_{1}\right)-B \\
x_{2}=\left(m_{b}+s m_{b}\left(1-m_{b}\right)\right)\left(p \pi_{1 H}^{I P O}+(1-p) \pi_{1}\right)-B \\
x_{3}=p m_{c} \pi_{1 H}^{I P O}+(1-p)\left[m_{c}-s m_{c}\left(1-m_{c}\right)\right] \pi_{1}-p B \\
x_{4}=p[m+s m(1-m)] \pi_{1 H}^{I P O}+(1-p) \pi_{1}-p B \\
y_{1}=(1-m)\left(p \pi_{2 H}+(1-p) \pi_{2}\right)-B \\
y_{2}=\left(1-m_{b}\right)\left(1-s m_{b}\right)\left(p \pi_{2 H}+(1-p) \pi_{2}\right) \\
y_{3}=\left(p \pi_{2 H}+(1-p) \pi_{2}\right)\left[p\left(1-m_{c}\right)+(1-p)\left(1-m_{c}\right)\left(1+s m_{c}\right)\right]-B \\
y_{4}=\left(p \pi_{2 H}+(1-p) \pi_{2}\right)\left[p\left(1-m_{b}\right)+(1-p)(1-m)\right]
\end{array} .\right.
$$

Now, given parametric conditions, it is easy to show that

$$
\left\{\begin{array}{l}
y_{1}<y_{2} \\
y_{3}<y_{4}
\end{array}\right.
$$

which means that remaining private is dominant for firm 2 at time 1 . And the final PBE depends on

$$
x_{2}-x_{4}=\operatorname{sm}_{b}\left(1-m_{b}\right)\left(p \pi_{1 H}^{I P O}+(1-p) \pi_{1}\right)+(1-m) s m(1-p) \pi_{1}-(1-p) B .
$$

When this condition is greater than 0 , the PBE is that firm 1 goes public at time 1 and firm 2 remains private for both periods. When this condition is less than 0 , the PBE is that both firms remain private at time 1 and firm 1 will go public at time 2 if the productivity shock is realized.

Similar analysis can be applied to the following three cases as well:

$$
\begin{aligned}
& \text { (II) } \frac{2+s-\sqrt{s^{2}+4}}{2 s}<m<\frac{1}{2} \Rightarrow(1-m) m>\left(1-m_{b}\right) m_{b}>\left(1-m_{c}\right) m_{c} \\
& \text { (III) } \frac{1}{2}<m<\frac{s-2+\sqrt{s^{2}+4}}{2 s} \Rightarrow(1-m) m>\left(1-m_{c}\right) m_{c}>\left(1-m_{b}\right) m_{b} \\
& \text { (IV) } \frac{s-2+\sqrt{s^{2}+4}}{2 s}<m<1 \Rightarrow\left(1-m_{c}\right) m_{c}>(1-m) m>\left(1-m_{b}\right) m_{b}
\end{aligned}
$$

The calculations are tedious but straightforward. If we use the following notations,

$$
\left\{\begin{array}{l}
x_{1}-x_{3} \equiv(* 1) \\
y_{3}-y_{4} \equiv(* 2) \\
x_{2}-x_{4} \equiv(* 3) \\
y_{1}-y_{2} \equiv(* 4)
\end{array}\right.
$$

the results for case (i) can be succinctly presented below:

$$
\text { If }(* 3)>0 \text { or }\left\{\begin{array}{l}
(* 3)<0 \\
(* 2)>0 \\
m>\frac{2+s-\sqrt{s^{2}+4}}{2 s}
\end{array} \text {, the time } 1 \text { equilibrium strategy is }(I P O, P R)\right. \text { and the time }
$$

2 equilibrium strategy is $(I P O, I P O, P R, P R) .{ }^{1}$ Otherwise, the time 1 equilibrium strategy is $(P R, P R)$ and the time 2 equilibrium strategy is ( $P O, P R, P R, P R)$. We should note that $\left({ }^{*} 1\right)$, $(* 2),(* 3)$ and $(* 4)$ bear different forms and values under different parametric conditions, which means that $x$ 's and $y$ 's do not necessarily look like those given in (A5).

Case (ii) $\Delta A \geq A_{1}-A_{2}$

\footnotetext{
${ }^{1}$ The equilibrium strategy at time 1 is given in the form of $\left(a_{1}, a_{2}, a_{3}, a_{4}\right)$ which correspond to the strategies adopted by firm 1 with shock, firm 1 without shock, firm 2 with shock, and firm 2 without shock, respectively.
} 
Basically we follow the same steps to solve the model. This time the results are more complicated yet more interesting as well. Since there are many parametric ranges that lead to the same PBE, we do not provide the long list of those conditions here. The general form of solutions can be described as: ${ }^{2}$

If $(* 1)>0$ and $(* 4)>0$, the time 1 equilibrium strategy is $(P R, P R)$ and the time 2 equilibrium strategy is $(I P O, P R, I P O, P R)$.

$$
\text { If }\left\{\begin{array}{l}
(* 3)>0 \\
(* 4)<0 \\
\left(1-m_{b}\right) s m_{b} \pi_{2 H}>B>\left(1-m_{b}\right) s m_{b} \pi_{2}
\end{array} \text {, the time } 1\right. \text { equilibrium strategy is (IPO, PR) }
$$

and the time 2 equilibrium strategy is (IPO,IPO,IPO, PR).

$$
\text { If }\left\{\begin{array}{l}
(* 3)>0 \\
(* 4)<0 \\
B>\left(1-m_{b}\right) s m_{b} \pi_{2 H}>\left(1-m_{b}\right) s m_{b} \pi_{2}
\end{array} \text {, the time } 1 \text { equilibrium strategy is }(I P O, P R)\right.
$$

and the time 2 equilibrium strategy is (IPO,IPO,PR,PR).

$$
\text { If }\left\{\begin{array}{l}
(* 3)<0 \\
(* 2)<0 \\
(1-m) s m \pi_{2 H}>B>(1-m) s m \pi_{1}>(1-m) s m \pi_{2}
\end{array} \text {, the time } 1\right. \text { equilibrium strategy }
$$

is $(P R, P R)$ and the time 2 equilibrium strategy is $(I P O, P R, I P O, P R)$.

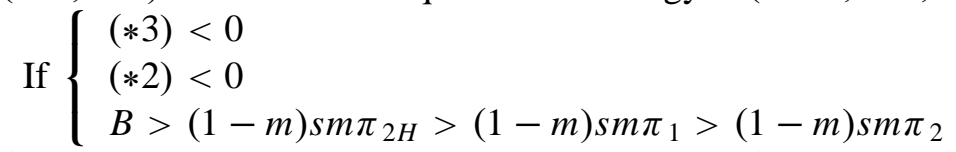

is $(P R, P R)$ and the time 2 equilibrium strategy is $(I P O, P R, P R, P R)$.

There may be rare cases where we have no PBEs or two PBEs (whose time 1 strategies are (I P O, I PO) and ( $P R, P R)$, respectively). For brevity, we do not provide detailed descriptions of these cases here. Last but not least, we can prove that when $x_{1}>x_{3}$, we always have $y_{3}<y_{4}$. This means that regardless of parameter values, $(P R, I P O)$ is never a time 1 equilibrium strategy.

When the productivity shock is industry-wide, the analysis is very similar to the case of idiosyncratic shocks. The only difference is that when the time 1 strategy profile is $(P R, P R)$, the uncertain situations faced by the two firms are reduced to two rather than four as before. With probability $p$, both firms' technology parameters $A_{i}^{\prime} s$ will increase by $\Delta A$ and with probability $1-p$ the parameters $A_{i}^{\prime} s$ will remain unchanged for the whole industry. All other analysis follows the same procedure as outlined above. To save space, we do not present the detailed list of all possible equilibria here, but they are available upon request.

Part (b): Characterizing the conditions under which different PBEs may occur.

After solving for all five possible PBEs in the model, we continue to characterize them in this section. For brevity, we only illustrate the case of industry-wide productivity shocks (Propositions 1, 2, and 3). The characterization of PBEs in the case of idiosyncratic productivity shocks is similar. To make our notations easy to follow, we define the following two boundaries for the magnitude of

\footnotetext{
${ }^{2}$ A complete list of all parametric conditions that lead to different PBEs can be provided to interested readers upon request.
} 
the shock $(\Delta A)$ :

$$
\begin{aligned}
\Delta A_{L} & \equiv\left(\frac{c}{\gamma}\right)^{\gamma}\left(\frac{B}{(1-\gamma) \operatorname{Max}\left\{s m(1-m), s m_{b}\left(1-m_{b}\right)\right\}}\right)^{1-\gamma}-A_{2} . \\
\Delta A_{H} & \equiv\left(\frac{c}{\gamma}\right)^{\gamma}\left(\frac{B}{(1-\gamma) \operatorname{Min}\left\{s m(1-m), s m_{b}\left(1-m_{b}\right)\right\}}\right)^{1-\gamma}-A_{2} .
\end{aligned}
$$

Figure 2 in the main text lists all possible PBEs under different ranges of market share distribution and the magnitude of the productivity shock. As we can see, when the magnitude of the shock is very large ( $\Delta A \geq \Delta A_{H}$ ), we only observe IPO-wave equilibria (Eq1, Eq2, and Eq3), whereas when the magnitude of the shock is small ( $\Delta A \leq A_{1}-A_{2}$ ), only off-the-wave IPOs may occur in equilibrium (Eq4 and Eq5). Eq1 may occur only when the magnitude of the shock is greater than $A_{1}-A_{2}$ (i.e., at least moderate), while Eq2 and Eq3 may occur only when $\Delta A$ is at least large ( $\Delta A>\Delta A_{L}$ ). When the magnitude of the shock is large but not very large $\left(\Delta A_{L}<\Delta A<\Delta A_{H}\right.$ ), the market share distribution matters: if $m$ is below $\frac{2+s-\sqrt{s^{2}+4}}{2 s}$, only Eq3 and Eq4 may occur rather than Eq2 or Eq5.

To differentiate the PBEs within each category of market share distribution and the magnitude of productivity shock, we need to look at the specific conditions for them to occur. From our proof in part (A), we know that the general rule is that Eq1 will occur when both $(* 1)>0$ and $(* 4)>0$; Eq2 and Eq4 will occur when both $(* 3)<0$ and $(* 2)<0$; and Eq3 and Eq5 will occur when $(* 3)>0 \&(* 4)<0$. A complete analysis of $(* 1),(* 2),(* 3)$, and $(* 4)$ shows that all these four conditions increase with $\Delta A$ and decrease with $B .(* 1)$ and $(* 3)$ increase with $A_{1}$, while $(* 2)$ and $(* 4)$ increase with $A_{2} .(* 1)$ and $(* 4)$ always increase with $p$, but $(* 2)$ and $(* 3)$ may increase or decrease with $p$. When $p$ is close to 1 and $m<\frac{2+s-\sqrt{s^{2}+4}}{2 s},(* 3)$ will decrease with $p$; and when $p$ is close to 1 and $m>\frac{s-2+\sqrt{s^{2}+4}}{2 s},(* 2)$ will decrease in $p$. In all other situations, both $(* 2)$ and $(* 3)$ increase in $p$. We find out these results by listing $(* 1),(* 2),(* 3)$, and $(* 4)$ for each parameter range and calculate their derivatives with respect to model parameters, $\Delta A, B, A_{1}, A_{2}$, and $p$. For brevity, the specific calculations case by case will not be presented here, but they are available upon request.

Q.E.D.

Proposition 4 (Average pre-IPO productivity and IPO timing) Consider an industry with parameter values such that all five possible PBEs in Propositions 1, 2, and 3 occur with positive probabilities. Then:

(i) firms that go public in an IPO wave will have lower average pre-IPO productivity than those that go public off the wave.

(ii) firms that go public earlier in an IPO wave will have higher average pre-IPO productivity than those that go public later in the wave.

Proof: Part (i) of the proposition is straightforward to prove. Consider an industry where all five possible PBEs in Propositions 1, 2, and 3 will occur with positive probabilities, then if we observe a stand-alone IPO, it must be conducted by firm 1 (possibly from Eq3, Eq4 and Eq5). That's why the pre-IPO productivity of such a firm is $A_{1}$. Similarly, if we observe an IPO wave in the sense that 
two IPOs occur during the period of time 1 and 2, then it must be the case that both firm 1 and 2 have gone public so the average pre-IPO productivity for such a firm is $\left(A_{1}+A_{2}\right) / 2$, which is lower than $A_{1}$.

Part (ii) of the proposition follows from the observation that if an IPO wave spans both time 1 and 2, then it must be from Eq3, which says that firm 1 will go public at time 1 and firm 2 will do so at time 2 when the productivity shock occurs. That's why the pre-IPO productivity for a firm that goes public earlier in such a wave $\left(A_{1}\right)$ is higher than that for a later comer in the IPO wave $\left(A_{2}\right)$.

Q.E.D.

Proposition 5 (Average post-IPO operating performance and IPO timing) Consider an industry with parameter values such that all five possible PBEs in Propositions 1, 2, and 3 occur with positive probabilities. Then, conditional on whether an industry-wide productivity shock has occurred:

(i) an average firm that goes public in an IPO wave will have lower post-IPO operating performance than an average firm that goes public off the wave.

(ii) an average firm that goes public earlier in an IPO wave will have higher post-IPO operating performance than an average firm that goes public later in the wave.

Proof: We also consider an industry where all five possible PBEs in Propositions 1, 2, and 3 will occur with positive probabilities. The post-IPO operating performance for firm $i$ is defined as:

$$
R O A_{i}^{I I I} \equiv \frac{m_{i}^{I I I}\left(A_{i}^{I I}\right)^{\frac{1}{1-\gamma}} C^{\frac{\gamma}{\gamma-1}} \gamma^{\frac{\gamma}{1-\gamma}}(1-\gamma)-B}{K_{0}+E}
$$

where $A_{i}^{I I}$ can be either $A_{i}$ or $A_{i H}$, depending on whether the industry-wide shock occurs. If two firms have identical initial capital level $\left(K_{0}\right)$, raise the same amount of equity $(E)$, pay the same issuing costs $(B)$, and have the same average post-IPO market share $\left(m_{i}^{I I I}=\bar{m}, i=1,2\right)$, then their post-IPO operating performance $\left(R O A_{i}^{I I I}\right)$ depends mainly on their post-IPO productivity $\left(A_{i}^{I I}\right)$. If these two average firms go public at different times of "market hotness", then the one that goes public alone will have an average post-IPO productivity of $A_{1 H}$ if the industry-wide productivity shock takes place (Eq4 and Eq5) and an average post-IPO productivity of $A_{1}$ if the productivity shock does not occur (Eq3 and Eq5). Thus the average post-IPO productivity for a stand-alone IPO firm based on the above updated posterior belief will be $p A_{1 H}+(1-p) A_{1}$, where $p$ is the ex ante belief that the industry-wide productivity shock will occur. Similarly, the average postIPO productivity for an on-the-wave IPO firm based on updated posterior belief will be $p\left(A_{1 H}+\right.$ $\left.A_{2 H}\right) / 2+(1-p)\left(A_{1}+A_{2}\right) / 2$. This completes the proof for part (i) of the proposition.

Part (ii) of the proposition can be proved in a similar fashion. Conditional on the occurrence of the productivity shock, the post-IPO productivity for a firm that goes public earlier in a "sequential IPO wave" (firm 1 in the model) will be $A_{1 H}$ whereas the post-IPO productivity for a firm that goes public later in the wave will be $A_{2 H}$. Similarly, conditional on no occurrence of the productivity shock, the post-IPO productivity for a firm that goes public earlier in a "sequential IPO wave" (firm 1 in the model) will be $A_{1}$ whereas the post-IPO productivity for a firm that goes public later in the wave will be $A_{2}$. In both cases, the equilibrium that results in such a sequential wave is Eq3, and the post-IPO productivity for a firm that goes public earlier in a wave is higher than that of a firm that goes public later in that same wave. Therefore, if these two firms have the same level of 
post-IPO capital stock and market share, the post-IPO operating performance for the early issuer will be better than that of the late one.

Q.E.D.

\section{Proposition 6 (Industry characteristics and IPO waves)}

(i) Industries whose productivity shocks have large magnitudes $\left(\Delta A>A_{1}-A_{2}\right)$ tend to have more IPOs and more IPO waves than industries whose shocks have smaller magnitudes $(\triangle A<$ $A_{1}-A_{2}$ ).

(ii) Industries with more innovation opportunities (large $p$ ) will have more IPOs and more IPO waves than industries with fewer or no innovations $(p \simeq 0)$.

(iii) IPO waves in industries whose higher-productivity firms have a smaller market share will last longer than IPO waves in industries whose higher-productivity firms also have a larger market share.

(iv) IPO waves in industries whose firms have larger gaps in productivity levels will last longer than IPO waves in industries whose firms have more homogeneous productivity levels.

Proof: Part (i) of the proposition compares industries with a small magnitude of productivity shocks $\left(\Delta A<A_{1}-A_{2}\right)$ and those with a large magnitude $\left(\Delta A>A_{1}-A_{2}\right)$. When $\Delta A$ is small so that $\pi_{2 H}<\pi_{1}$, we have the situation as in Proposition 3 where the only equilibria (Eq4 and Eq5) involve at most one IPO (by firm 1) and no IPO waves can occur. However, when $\Delta A$ is sufficiently large so that $\pi_{2 H}>\pi_{1}$, the same industry may witness more IPOs and IPO waves due to the going-public efforts by firm 2 such as those in Eq1, Eq2, and Eq3.

Even within an industry with either $\Delta A<A_{1}-A_{2}$ or $\Delta A>A_{1}-A_{2}$, a greater $\Delta A$ will contribute to stronger incentives to go public. For example, in an industry with $\Delta A<A_{1}-A_{2}$, we may observe either Eq4 or Eq5. Eq5 yields stronger going-public incentives because in this equilibrium firm 1 will go public at time 1 before the realization of any productivity shocks. On the contrary, in Eq4 firm 1 will wait until time 2 to do its IPO when the industry-wide productivity shock actually occurs. Thus we may compare the likelihood of Eq4 and that of Eq5 to see the effect of $\Delta A$ on going-public concerns. As we show in the proof of Proposition 1,2 , and 3 , the conditions for Eq5 to occur rather than Eq4 is:

$$
(* 3)>0 \text { or }\left\{\begin{array}{l}
(* 3)<0 \\
(* 2)>0 \\
m>\frac{2+s-\sqrt{s^{2}+4}}{2 s}
\end{array} .\right.
$$

In the case of $0<m<\frac{2+s-\sqrt{s^{2}+4}}{2 s}$, we have shown that $(* 3)>0$ is equivalent to

$$
x_{2}-x_{4}=\operatorname{sm}_{b}\left(1-m_{b}\right)\left(p \pi_{1 H}^{I P O}+(1-p) \pi_{1}\right)+(1-m) s m(1-p) \pi_{1}-(1-p) B>0,
$$

the left handside of which is clearly increasing in $\Delta A$ (because $\pi_{1 H}^{I P O}$ increases with $\Delta A$ ). In fact, as $\Delta A$ decreases to $0,(* 3)<0$ for sure. Similarly, $(* 2)>0$ is equivalent to

$$
y_{3}-y_{4}=\left(p \pi_{2 H}+(1-p) \pi_{2}\right)\left[(1+p)(1-m) s m+(1-p)\left(1-m_{c}\right) s m_{c}\right]-B>0,
$$


whose left handside also increases with $\Delta A$ as $\pi_{2 H}$ rises with $\Delta A$. As $\Delta A$ decreases to $0,(* 2)<0$ for sure. Combining the above results, we can see that a larger $\Delta A$ tends to increase the likelihood that Eq5 occurs, even if it is smaller than $A_{1}-A_{2}$. We have repeated the analysis in all other possible cases and shown that the conclusion is true for all of them. (For brevity the detailed proofs are not listed here.)

Part (ii) of Proposition 6 also follows from Proposition 1, 2, and 3. The conditions (4) and (5) ensure that without productivity shocks ( $p \simeq 0$ ), firms will optimally choose to remain private. Hence, an industry with large enough probability of productivity shocks will tend to witness more IPOs and IPO waves. Similar to the proof for part (i), we can show that within an industry with either $\Delta A<\Delta A_{L}$ or $\Delta A>\Delta A_{H}$, a greater $p$ will always contribute to stronger incentives to go public. For example, in an industry with $\Delta A<A_{1}-A_{2}$, we may observe either Eq4 or Eq5. Eq5 yields stronger going-public incentives thus we may compare the likelihood of Eq4 and that of Eq5 to see the effect of $p$ on going-public concerns. As we show in the proof of part (i) of Proposition 6, the condition for Eq5 to occur rather than Eq4 is (??). Since $x_{2}-x_{4}$ is linear in $p$, it's easy to show that $x_{2}-x_{4}$ increases with $p$ by comparing its value when $p$ is 0 and 1 . When $p=0, x_{2}-x_{4}<0$ for sure and vice versa when $p=1$. Hence, $p$ increases $x_{2}-x_{4}$. Similarly, it is straightforward to show that $y_{3}-y_{4}$ increases with $p$ as well. Combining the above results, we can see that a larger $p$ tends to increase the likelihood that Eq5 occurs, even if $\Delta A$ is smaller than $A_{1}-A_{2}$. We can repeat the analysis in other possible cases when either $\Delta A<\Delta A_{L}$ or $\Delta A>\Delta A_{H}$. However, when $\Delta A$ is moderate, $p$ 's effect on going-public incentives may be ambiguous (with intuition given in the main text). Hence, part (ii) of Proposition 6 only compares industries with very high $p$ and those with $p \simeq 0$. Then regardless of the magnitude of $\Delta A$, industries with higher $p$ will unambiguously have more IPOs and IPO waves.

Part (iii) of this proposition follows Proposition 1 and 2. As we can see in Figure 2 in the main text, among the three IPO-wave equilibria, the occurrence of the Eq1 is not affected by the market share distribution while Eq2 and Eq3 do. When the higher-productivity firm, firm 1, has small enough existing market share ( $m<\frac{2+s-\sqrt{s^{2}+4}}{2 s}$ ), only Eq3 can occur, resulting in a longer wave period (both time 1 and time 2) than when firm 1's market share is larger than $\frac{2+s-\sqrt{s^{2}+4}}{2 s}$, in which case only Eq2, whose wave takes place at time 2, may occur.

Part (iv) follows Proposition 1 and 2 as well. When the existing productivity level of firm 1 is high while that of firm 2 is low, Eq3 is more likely to occur than when both firms' productivity levels are similar (either both high as in Eq1, or both low as in Eq2). In Eq3, the IPO wave will span the whole period of time 1 and 2, while in the latter two cases any IPO waves will only take place simultaneously, either at time 1 or 2 .

Q.E.D. 